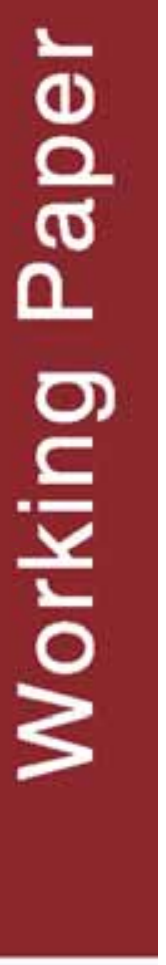

Ni'matul Khasanah, Elok Mulyoutami, Andree Ekadinata, Tonni Asmawan, Lisa Tanika, Zuraida Said, Meine van Noordwijk, Beria Leimona 



\section{A Study of Rapid Hydrological Appraisal in the Krueng Peusangan Watershed, NAD, Sumatra}

Ni'matul Khasanah, Elok Mulyoutami, Andree Ekadinata, Tonni Asmawan, Lisa Tanika, Zuraida Said, Meine van Noordwijk, Beria Leimona

Working Paper nr 123 


\section{$4 \%$ \\ World Agroforestry Centre \\ TRANSFORMING LIVES AND LANDSCAPES}

\section{Correct citation:}

Khasanah K, Mulyoutami E, Ekadinata A, Asmawan T, Tanika L, Said Z, van Noordwijk M, and Leimona B. 2010. A Study of Rapid Hydrological Appraisal in the Krueng Peusangan Watershed, NAD,

Sumatra. Working paper nr.123. Bogor, Indonesia. World Agroforestry Centre.53p. DOI: 10.5716/ WP10339.PDF

Titles in the Working Paper Series aim to disseminate interim results on agroforestry research and practices and stimulate feedback from the scientific community. Other publication series from the World Agroforestry Centre include: Agroforestry Perspectives, Technical Manuals and Occasional Papers.

Published by

World Agroforestry Centre

ICRAF Southeast Asia Regional Office

PO Box 161, Bogor 16001, Indonesia

Tel: +622518625415

Fax: +62 2518625416

Email: icraf-indonesia@cgiar.org

http://www.worldagroforestrycentre.org/sea

(C) World Agroforestry Centre 2010

Working Paper nr 123

\section{Photos:}

The views expressed in this publication are those of the author(s) and not necessarily those of the World Agroforestry Centre.

Articles appearing in this publication may be quoted or reproduced without charge, provided the source is acknowledged.

All images remain the sole property of their source and may not be used for any purpose without written permission of the source. 


\section{About the authors}

\section{Ni'matul Khasanah}

Ni'matul Khasanah (Ni'ma) joined ICRAF since 2002 and mostly working with Water, Nutrient and Light Capture in Agroforestry (WaNuLCAS) models for a wide range of agroforestry systems for various research context. She has a MSc degree on Agroclimatology in Bogor Agriculture University (IPB). Currently, her research interest within natural resource management area include watershed management and climate change issues. Contact: n.khasanah@cgiar.org

\section{Elok Mulyoutami}

Elok joined ICRAF since 2003 and mostly involve on study related with local knowledge and farming systems in Agroforest Management Unit. She was born in Bandung and took her bachelor degree in Anthropology, Social and Political Faculty in Padjadjaran University, Bandung, West Java. Currently, her research interest is also include local livelihood, socio-economic issues, as well as environmental and ecological services. Contact: e.mulyoutami@cgiar.org.

\section{Andree Ekadinata}

Andree Ekadinata is a Remote Sensing Specialist, primarily focuses on image processing and spatial analysis for natural resource management, including biodiversity assessments. Andree joined ICRAF since 2001 as BSc student and involved in ICRAF as Remote Sensing Specialist up to present. He has extensive experiences in interpreting imageries across areas in Southeast Asia, Africa and Latin America, as well as across broad application and research questions within natural resource management areas, such as climate change mitigation, watershed management and spatial land use planning. Contact: a.ekadinata@cgiar.org.

\section{Tonni Asmawan}

Tonni was born on 8 December 1981 in Bogor, West Java, Indonesia. He graduate bachelor degree on Forest Resourch Conservation Faculty of Forestry Bogor Agricultural University (IPB). He joined ICRAF since 2007 as junior scientist of hydrology up to present. His main research interest includes hydrology monitoring, partisipatory landscape appraisal, and environmental services. Tonni's email address is t.asmawan@cgiar.org.

\section{Lisa Tanika}

Lisa was born in Semarang, Central Java on 24 December 1983. She has graduated from Bogor Agriculture University. with majoring Mathematics. She joined ICRAF since June 2008 as ecological modeller. Her interest research is about hydrological modeller and the impact of land cover change on the quality of watershed. Contact: 1.tanika@cgiar.org or lisa.tanika@yahoo.com. 


\section{Zuraida Said}

Zuraidah was born in Jakarta on 10th September 1984. She graduated from Bogor Agriculture University (IPB) on 2006 as Bachelor in Agriculture (Soil Science Major) with thesis titled "Study of ASAR-Envisat Satellite Image Calibration Process for Biomass Application in Pelalawan Plantation Forest, Riau". Zuraidah joined ICRAF since December 2008 as Remote Sensing and GIS Research Assistant up to present. In ICRAF she is responsible in providing spatial data and analyses for some researches linked to Geography Information System and Remotely Sense data. Contact: z.said@cgiar.org

\section{Meine van Noordwijk}

Meine van Noordwijk is an ecologist who joined the Centre's Southeast Asia Program in Bogor in 1993 to support the activities of the Alternatives to Slash and Burn Program, now the ASB Partnership for the Tropical Forest Margins. He served as regional coordinator from 2002-2009 and is now the Centre's Chief Science Advisor. He obtained his $\mathrm{PhD}$ in 1987 from Wageningen Agricultural University in the Netherlands. Contact: m.vannoordwijk@ cgiar.org.

\section{Beria Leimona}

Beria Leimona joined World Agroforestry Centre - Southeast Asia (ICRAF-SEA) in January 2002. She is currently the coordinator for Reward for, Use of and shared investment in Pro-poor Environmental Services (RUPES II) program. Her major concern is developing and overseeing propoor reward for environmental services initiatives in Asia together with international donor organizations, regional government partners, research and civil society organizations. She obtained her bachelor and master degrees on Landscape Architecture at Bogor Agricultural University. She is currently pursuing her doctoral degree at Wageningen University and Research, the Netherlands. Contact:1.beria@cgiar.org. 


\section{Summary}

The Krueng Peusangan Watershed is categorized as degraded area with $1^{\text {st }}$ priority by the Department of Public Work and Water Resource Services of Aceh Province (Departemen Pekerjaan Umum dan Dinas Sumber Daya Air, Aceh province) meaning this watershed has experienced very severe degradation and needs high priority to improve its situation. The Aceh Provincial Government developed a strategic planning of integrated and sustainable watershed management of the Krueng Peusangan watershed to prevent further watershed degradation. Aligned to the development of the strategic planning, WWF in collaboration with the World Agroforestry Centre (ICRAF) SEA Regional Program conducted a comprehensive hydrology study from the perspective of multiple stakeholders using the Rapid Hydrological Appraisal (RHA) method.

The objectives of the RHA are to appraise the hydrological situation from the perspective of multiple stakeholders: local ecological knowledge (LEK), public/policymakers ecological knowledge (PEK), and hydrologist/modeler ecological knowledge (MEK). Further, the recommendation from the application of RHA is to design a realistic approach in designing a reward for watershed services scheme. To accomplish the objective of the study, the RHA method was implemented through the following activities:

1. Survey and exploration of the two main types of stakeholder knowledge: local and public/policy maker ecological knowledge on water movement and causes and consequences of land use options on the landscape from the perspective of multiple users of the Krueng Peusangan watershed,

2. Gathering and analyzing of existing climate and hydrology data on the Krueng Peusangan watershed,

3. Spatial data analysis of the Krueng Peusangan watershed to obtain land cover information, land cover change information and watershed characteristic,

4. Analyses of the consequences of current land cover change on the values of water balance including river flow in the Krueng Peusangan watershed using GenRiver 2.0 model, and

5. Analyses of plausible future land cover changes scenarios and its impacts using GenRiver 2.0 model.

The Krueng Peusangan watershed is a cross-district watershed with a lake located in its upper part and consists of 11 sub-watersheds. It has moderately high rainfall and wet seasons. In the upper watershed, the Gayo people live along the river and surrounding the Lake Laut Tawar, while the Aceh people live in mid and downstream of the watershed. The Gayo people mostly planted upland rice, coffee, cocoa, and pinang under both monoculture and mixed crop systems. The Acehnese practiced fishing and cultivated irrigated paddy, coconut, oil palm, and mixed garden.

Our survey resulted that both upstream and downstream communities recognized the importance of river; however, they had different opinions of the major problem of the watershed. The upstream community mentioned decreasing river flow, low water quality and sedimentation as the problems, while the mid- and downstream community considered disaster as the main problems, such as riverbank collapse (abrasion) and flood causing economic lost to them. We found that the locals 
were also familiar with tree species with high capacity to reduce erosion and simple constructions to maintain the stability of riverbank.

Our interview with policy makers, such as district and provincial government officers revealed that the Krueng Peusangan watershed had important economical and ecological roles. While mentioning abrasion, erosion, flooding and sedimentation as the problems they faced, they considered forest clearing and mining activities, and wild foraging as the main causes of these problems.

Our analysis of land cover change in $1990-2009$ showed that the watershed had experienced decrease of forest and pine forest cover (about 40\%) and increase of settlement, oil palm plantation and other tree cover systems such as coffee agroforest, both monoculture and complex mixed tree crops. As the consequences of tree cover decrease in the landscape for the last 20 years, the total water yield as a fraction of total rainfall increased. High total water yield especially under intensive rainfall events contributed to increasing surface flow and lead to floods, soil erosion and riverbank abrasion.

The study analyzed 5 scenarios to understand the impact of land use change to the key hydrological parameters of the Krueng Peusangan watershed. The scenarios vary from "business as usual" with 4 percent decrease of forest over time, mild level increment of tree cover, such as increase of complex mixed tree crop and/or pine forest, and extreme increment of tree cover with full natural forest cover except for the settlement.

We found that the water balance did not differ significantly under conversion of non-tree cover system to complex mixed tree crop and logged over forest to pine forest, or the combination of both (Scenario 1,2,3) because the affected area is relatively small (10-15\% of the total area). Reforesting all land cover in the watershed except settlement area (scenario 5) resulted on increase in evapotransporation (50\%) and decrease in river discharge (25\%). Reforesting part of the watershed, such as bareland and logged over forest and converting monoculture crop and plantation to complex mixed tree system (scenario 4) gave slightly lower water balance (evapotranspiration and river flow) trend compare to scenario 5. There is also a slight increase in soil base flow for both scenarios 4 and 5. It is imply that there is transfer of surface runoff into soil base flow. Shifts in this pathway that water takes to reach the river, from current surface flow to an increase in base flow will depend on the rate of recovery of soil physical conditions.

This study gave basic understanding in designing rewards for environmental service schemes (RES) in the Krueng Peusangan watershed. It proved that modification of parts of the watershed to forest and/or complex mixed system can enhance water balance of the watershed. We also found out that the local knowledge in this area could contribute greatly to the tree selection and solution to watershed problem, such as simple constructions to retain collapse riverbank. Therefore, recognition of such knowledge will become an important element in the RES design. Layered stakeholders and complex issues of land cover in this watershed suggest that applying a direct - supply demand payment for environmental services might not work at the initial stage of the process. The site manager may want to build a joint investment approach in solving the problems and managing the watershed, between communities who maintain a healthy watershed (ES providers) and ones who benefit from it (ES beneficiaries). The co-investment scheme, in principle, is to have strong trust and 
commitment in order to gain benefits and share risks together between ES providers and ES beneficiaries.

For the next step of research, we recommend a follow up study on (1) the effects of coffee agroforestry and other forest derived land uses on soil physical conditions; (2) explore types of tress preferred by the communities with ecological and economical values. 


\section{Acknowledgements}

This RHA study financially supported by World Wide Fund for Nature (WWF) Indonesia and this working paper is produced under Trees in multi-Use Landscapes in Southeast Asia (TUL-SEA) Project funded by the Federal Ministry for Economic Cooperation and Development (BMZ) Germany. 
Table of Content

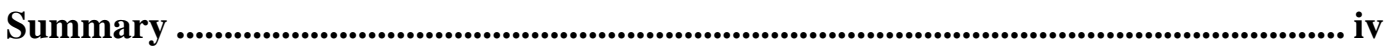

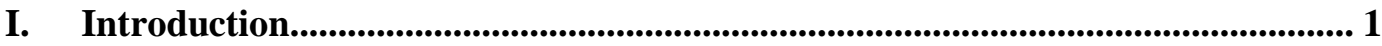

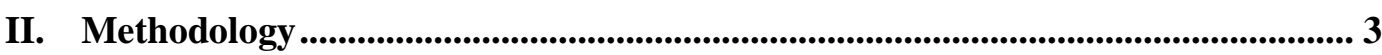

2.1. Knowledge Surveys and Stakeholder Analysis .................................................... 3

2.2. Analysis of Climate and Hydrology Data ……………............................................. 5

2.3. Analysis of Land Cover/Land Cover Change and Watershed Characteristic .................. 6

2.4. Analyses of the Consequences of Current and Future Land Cover Change

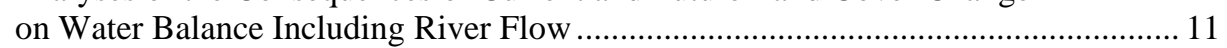

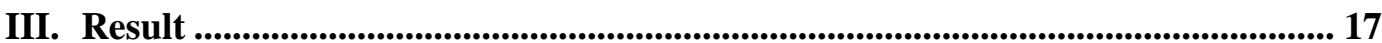

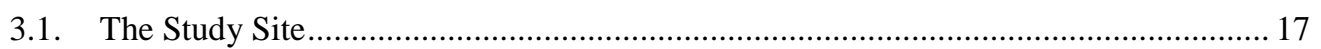

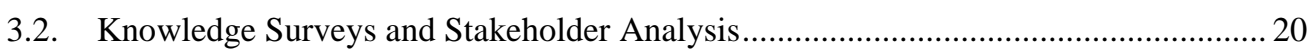

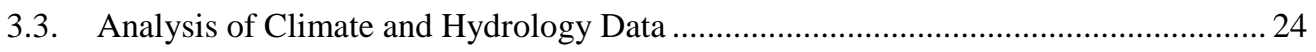

3.4. Spatial Analysis: Land Cover/Land Cover Change and Watershed Characteristic

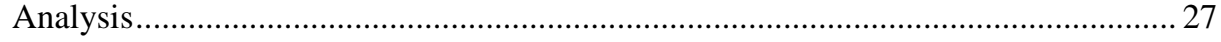

3.5. Analyses on the Consequences of Current and Future Land Cover Change on Water Balance Including River Flow ......................................................................... 34

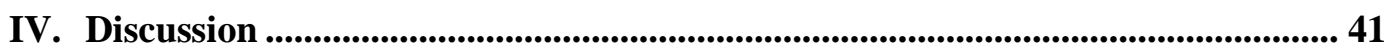

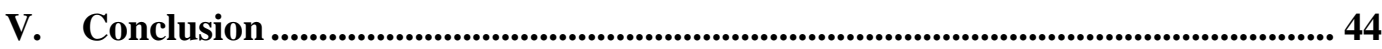

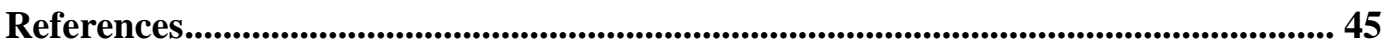

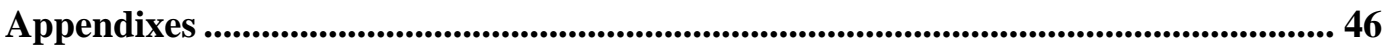




\section{Introduction}

The Krueng Peusangan watershed is one of the main watersheds in Nanggroe Aceh Darussalam province. Its total area is about 238,550 ha and it includes four regencies (kabupaten), an upstream area in Aceh Tengah, a mid stream area in Bener Meriah, and a downstream area in Bireun and Aceh Utara. Communities outside of the Krueng Peusangan watershed are also stakeholders as they derive benefits from the Peusangan river, including companies in Lhokseumawe.

Forest degradation has been mainly caused by timber extraction and forest fire. Due to the rebuilding efforts after the tsunami disaster hit Aceh province at the end of 2004, timber extraction have drastically increased. Forest fire occurs mostly during dry season especially in easily burnt pine forest (located alongside Lake Laut Tawar). Flooding as well as riverbank abrasion occurs during high rainfall events. Other issues mentioned are the perceived decrease of river flow during dry seasons and a decreasing lake volume.

In policy documents, the current situation of the Krueng Peusangan Watershed is categorized as degraded area priority 1 . The Aceh Provincial Government developed strategic planning of integrated and sustainable watershed management of the Krueng Peusangan watershed to prevent further watershed degradation. Aligned to the development of the strategic planning, WWF in collaboration with the World Agroforestry Centre (ICRAF) SEA Regional Program conducted a comprehensive hydrology study on watershed function from the perspective of multiple stakeholders using the Rapid Hydrological Appraisal (RHA) method (Jeanes et al., 2006).

The generic term of 'watershed function' means different things to different stakeholders and in different situations and it may be constrained by gaps between three types of knowledge (Figure 1). In discussions between upstream and downstream land users, public policy, and science, the three types of 'knowledge' (local, public and scientific) are interacting, often expressed in languages that have little in common and using concepts that may be considered 'myths' by other stakeholder groups (Jeanes, et al., 2006).

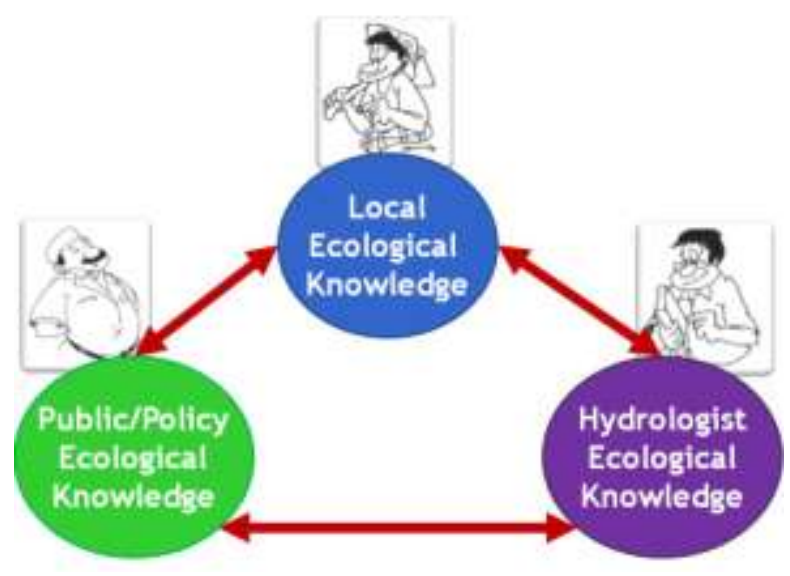

Figure 1. Three types of knowledge deal with in understanding the hydrological situation. 
The objectives of the RHA are as follow:

1. To appraise the hydrological situation from the perspective of multiple stakeholders: local ecological knowledge, public/policymakers ecological knowledge, and hydrologist/modeler ecological knowledge,

2. To identify existing gaps between the three types of knowledge and to provide integrated analysis to assess hydrological situation, and

3. To develop plausible future watersheds management scenarios using GenRiver 2.0 model for further exploration and development of rewards for watershed services. 


\section{Methodology}

To accomplish the objective of the study, the RHA approach was implemented through the following activities (Figure 2):

1. Survey and exploration of the two main types of stakeholder knowledge: local and public/policy maker ecological knowledge (LEK and PEK) on water movement and causes and consequences of land use options on the landscape from the perspective of multiple users of the Krueng Peusangan watershed,

2. Gathering and analyzing of existing climate and hydrology data on the Krueng Peusangan watershed,

3. Spatial data analysis of the Krueng Peusangan watershed to obtain land cover information, land cover change information and watershed characteristic,

4. Analyses of the consequences of current land cover change on the values of water balance including river flow in the Krueng Peusangan watershed using GenRiver 2.0 model, and

5. Analyses of plausible future land cover changes scenarios and its impacts using GenRiver 2.0 model.

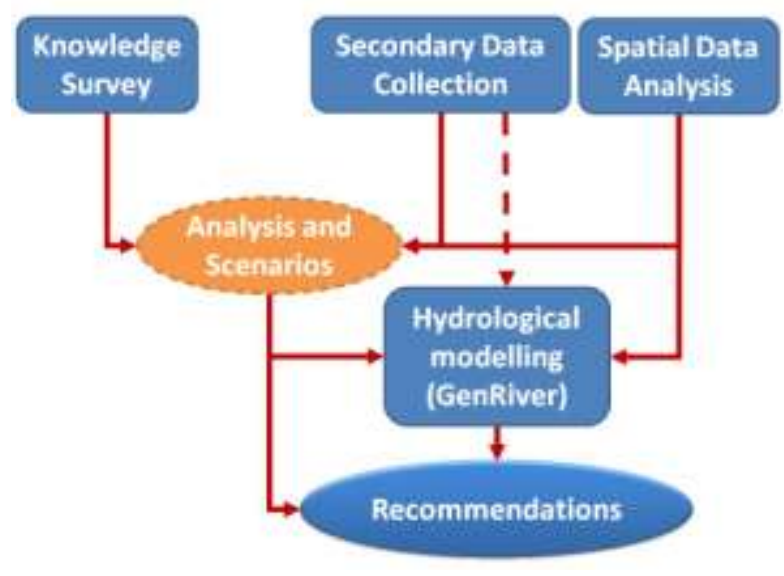

Figure 2. Rapid Hydrological Appraisal activities

\subsection{Knowledge Surveys and Stakeholder Analysis}

The objectives of the PEK and LEK surveys are:

1. To explore and articulate the knowledge, experience and perceptions of the major groups of people/institutions who have direct influence upon the management of all sub-catchments of the Krueng Peusangan watershed.

2. To explore and articulate the knowledge, experience and perceptions of the selected local communities which have direct influence upon the management of one focus subcatchments.

To accomplish those objectives, the knowledge acquisition method adapted from the knowledge based system approach (Dixon, et al., 2001) was used. LEK and PEK survey were conducted with 
some modification in data collection to reduce time and expenditure. A series of discussions with the same groups within the community were conducted as well as few individual interviews by snow ball techniques to find the supposedly representative and most knowledgeable persons. In the analytical stage, statements from local people were extracted and presented in diagram form to show the interrelationship between the statements.

Stakeholder analysis was conducted before a series of individual interviews and documentation review with relevant stakeholders. This is important to provide useful material for description of the stakeholders who are keys to watershed management and potential rewards schemes.

The knowledge surveys were conducted along with spatial and hydrological surveys. Steps in the knowledge survey are presented in Table 1. In order to portray the condition of local knowledge of people living along the Krueng Peusangan watershed, we conducted surveys in three main areas: (1) upstream and midstream area of Aceh Tengah district; (2) upstream and midstream area of Bener Meriah district, and (3) downstream area in Bireun and Aceh Utara district. We assumed that potential ES buyers/investors might include KKA (Kertas Kraft Aceh), a private paper industry located in Aceh Utara and Lhokseumawe.

We organized three series of focus group discussion at community level in coordination with SILVA in Lhokseumawe, Aceh Green Care in Bireun, and Forum Danau Laut Tawar in Takengon. SILVA, Aceh Green Care and the Forum Danau Laut Tawar are local NGOS concerned with environmental issues, and they are also WWF partner dealing with watershed protection issues in Aceh.

Table 1. Steps of LEK and PEK survey on RHA

\begin{tabular}{|c|c|c|}
\hline Step & Methods & Output \\
\hline \multirow[t]{3}{*}{ Scoping } & \multirow[t]{3}{*}{$\begin{array}{l}\text { Literature review } \\
\text { Desktop review } \\
\text { Observation and field trip }\end{array}$} & $\begin{array}{l}\text { For overall study: } \\
\text { Base map and domain description } \\
\text { Decision on survey spatial focus (location) } \\
\text { for knowledge surveys }\end{array}$ \\
\hline & & $\begin{array}{l}\text { Only for PEK survey: } \\
\text { Stakeholder identification } \\
\text { Definition of watershed or basin }\end{array}$ \\
\hline & & $\begin{array}{l}\text { Only for LEK survey: } \\
\text { Community profile } \\
\text { Definition of sub-catchment boundaries }\end{array}$ \\
\hline \multirow[t]{2}{*}{ Planning for interview } & \multirow{2}{*}{$\begin{array}{l}\text { Literature review } \\
\text { Desktop review } \\
\text { Definition of focus sub-catchment } \\
\text { boundaries }\end{array}$} & $\begin{array}{l}\text { Community typology (group) defined } \\
\text { Checklist question ready }\end{array}$ \\
\hline & & $\begin{array}{l}\text { Stakeholder identification resulted } \\
\text { Checklist question ready }\end{array}$ \\
\hline \multirow[t]{2}{*}{ Knowledge articulation } & $\begin{array}{l}\text { Local knowledge surveys } \\
\text { Group discussions } \\
\text { Transects visits }\end{array}$ & \multirow{2}{*}{$\begin{array}{l}\text { Summary of general output and } \\
\text { methodology, summarize interview data (to } \\
\text { database if necessary), key issue analyze, } \\
\text { problems areas and perception captured. }\end{array}$} \\
\hline & $\begin{array}{l}\text { Stakeholder analysis } \\
\text { Interview and discussion }\end{array}$ & \\
\hline $\begin{array}{l}\text { Data compilation and } \\
\text { evaluation }\end{array}$ & $\begin{array}{l}\text { Transcription record } \\
\text { Clarification of results } \\
\text { Revisiting some informants and re- } \\
\text { discussing on unclear items } \\
\text { Field report preparation }\end{array}$ & $\begin{array}{l}\text { Data set } \\
\text { Draft Report }\end{array}$ \\
\hline
\end{tabular}




\subsection{Analysis of Climate and Hydrology Data}

We applied the GenRiver 2.0 to model the influence of current and future land use change to watershed hydrological situation. The application of such model needs minimum 20 years timeseries climatic and hydrological data covering all sub-catchment. Table 2 presented the available climatic and hydrological data of the Krueng Peusangan watershed.

Table 2. Available data on climate and hydrology of the Krueng Peusangan watershed.

\begin{tabular}{|c|c|c|c|c|}
\hline & Data & Source & Series & $\begin{array}{l}\text { Coverage } \\
\text { area }\end{array}$ \\
\hline \multirow[t]{6}{*}{ Climate } & \multirow[t]{3}{*}{ Daily rainfall } & $\begin{array}{l}\text { Station meteorologi } \\
\text { Class III Lhokseumawe, } \\
\text { Malikussaleh Airport }\end{array}$ & $1990-2009^{1)}$ & Downstream \\
\hline & & $\begin{array}{l}\text { Public Work Agency } \\
\text { Aceh province }\end{array}$ & $2008-2009$ & Upstream \\
\hline & & $\begin{array}{l}\text { Agricultural Agency, } \\
\text { Takengon }\end{array}$ & 2009 & Upstream \\
\hline & Monthly rainfall & $\begin{array}{l}\text { Agricultural Agency, } \\
\text { Takengon }\end{array}$ & $1993-2008$ & Upstream \\
\hline & Monthly rainfall & www.worldclim.com & $\begin{array}{l}\text { Average data: } \\
\text { Current }(1950- \\
2000) \\
\text { Future }(>2000)^{1)}\end{array}$ & $\begin{array}{l}\text { Krueng } \\
\text { Peusangan } \\
\text { watershed }\end{array}$ \\
\hline & $\begin{array}{l}\text { Supporting climate data: } \\
\text { potential } \\
\text { evapotranpiration }\end{array}$ & $\begin{array}{l}\text { Station meteorologi } \\
\text { Class III Lhokseumawe, } \\
\text { Malikussaleh Airport }\end{array}$ & $1999-2009^{1)}$ & \\
\hline \multirow[t]{2}{*}{ River flow } & $\begin{array}{l}\text { Daily river flow of } \\
\text { Beukah station }\end{array}$ & \multirow[t]{2}{*}{ PUSAIR, Bandung } & $1991-1997^{1)}$ & $\begin{array}{l}\text { Krueng } \\
\text { Peusangan } \\
\text { watershed } \\
\end{array}$ \\
\hline & $\begin{array}{l}\text { Daily river flow of } \\
\text { Simpang Jaya station }\end{array}$ & & $1991-1997$ & $\begin{array}{l}\text { Krueng } \\
\text { Peusangan } \\
\text { watershed }\end{array}$ \\
\hline
\end{tabular}

1) Data used for GenRiver model simulation

\subsubsection{Analysis of Rainfall Data}

The long-period daily rainfall data covering all sub-catchment of the Krueng Peusangan watershed was not available (Table 2). As the solution, we generated the data using the rainfall simulator model (van Noordwijk, in press) based on available monthly rainfall data from Worldclim (www.worldclim.com) as an input for running GenRiver model. The rainfall simulator model considers temporal autocorrelation of rainfall, shape of daily rainfall, frequency distribution, seasonal pattern of wet and dry months and annual rainfall.

The main input parameters of rainfall simulator model are:

1. Frequency distribution (number of rainy day per month); seasonal pattern of wet and dry months; and annual mean rainfall for each year. Daily rainfall data of station Meteorologi Class III Lhokseumawe, Malikussaleh Airport is used to generate these input parameters.

2. Annual and monthly rainfall data. Average of annual and monthly rainfall data of extracted from Worldclim from period 1950 - 2000 and current is used.

Coefficient correlation and bias analysis are used to evaluate the model performance by comparing measured to predicted monthly and annual rainfall using equation presented in Appendix 1. 


\subsubsection{Analysis of River flow Data}

The river flow data is available for six years only. A series of test of consistency of river flow data of Beukah station prior to the use of data as an input for running GenRiver model include:

- Calculate the different of yearly total precipitation and river flow ( $\Sigma \mathrm{P}-\Sigma \mathrm{Q})$, it gives an estimate of total evapotranspiration. Values below 500 or above $1500 \mathrm{~mm} /$ year are suspect. These may indicate errors in $\mathrm{P}$ or $\mathrm{Q}$ registration, error in the area or deviation from the 'closed catchment' assumption (e.g. subsurface flows out of or into the catchment are nonnegligible).

- Plot 'Double Mass' curves of cumulative $\Sigma \mathrm{Q}$ versus $\Sigma \mathrm{P}$ during the year: large jumps will require explanation.

- Plot flow persistence $\mathrm{Q}_{\mathrm{i}+\mathrm{I}}$ versus $\mathrm{Q}_{\mathrm{i}}$, it may indicate gaps in the data or 'outliers' that indicate errors.

\subsection{Analysis of Land Cover/Land Cover Change and Watershed Characteristic}

The way people manage their land will affect the hydrological characteristics of a landscape. Therefore, understanding landscape composition, landscape configuration and its dynamics over time and space is an important phase in RHA. The characteristic of hydrological features within a watershed or catchment area can be defined by observing several landscape components such as: land use composition, topography, soil and geology.

On the other hand, information on land use configuration and its dynamics over time and space provides an important proxy on the quality of the watershed. We use spatial analysis to provide information, analyze landscape configuration and land use dynamics in the Krueng Peusangan watershed. Our approach consist of three steps: (1) spatial data acquisition, (2) terrain processing, and (3) analysis of land use/cover change and trajectories (ALUCT).

\subsubsection{Spatial data}

Spatial analyses for RHA were conducted using several types of spatial data. In general, three types of data are required: satellite image for land cover mapping, digital elevation model for watershed characterization and thematic maps for analysis of landscape configuration. Some of the data can be acquired from secondary sources, i.e. government agency or research institution, while some had to be generated from primary data sources.

\section{Satellite image}

Time series satellite images are required to produce a time series land cover map of the Krueng Peusangan watershed. The land cover maps will provides estimation on land use dynamics in the study area. We used $30 \mathrm{~m}$ Landsat images acquired from Earth Resource Observation and Science (EROS) Centre (http://eros.usgs.gov/). List of satellite image and its acquisition date is shown in Table 3. The time series satellite images are shown in Figure 3. 
Table 3. List of satellite images for the Krueng Peusangan watershed

\begin{tabular}{lll}
\hline Theme & Path/Row & Acquisition date \\
\hline Satellite image & & \\
\hline Landsat TM 1990 ‘s & P130r056 & 6 January 1990 \\
& P130r057 January 1990 \\
\hline Landsat ETM 2000's & P130r056 & 5 May 2000 \\
& P130r057 & 5 May 2000 \\
\hline Landsat ETM SLC-off & P130r056 & 7 January 2005 \\
2005's & P130r057 & 3 June 2006 \\
\hline Landsat ETM SLC-off & P130r056 & 5 January 2010 \\
2009's & P130r057 & 24 April 2009 \\
\hline
\end{tabular}
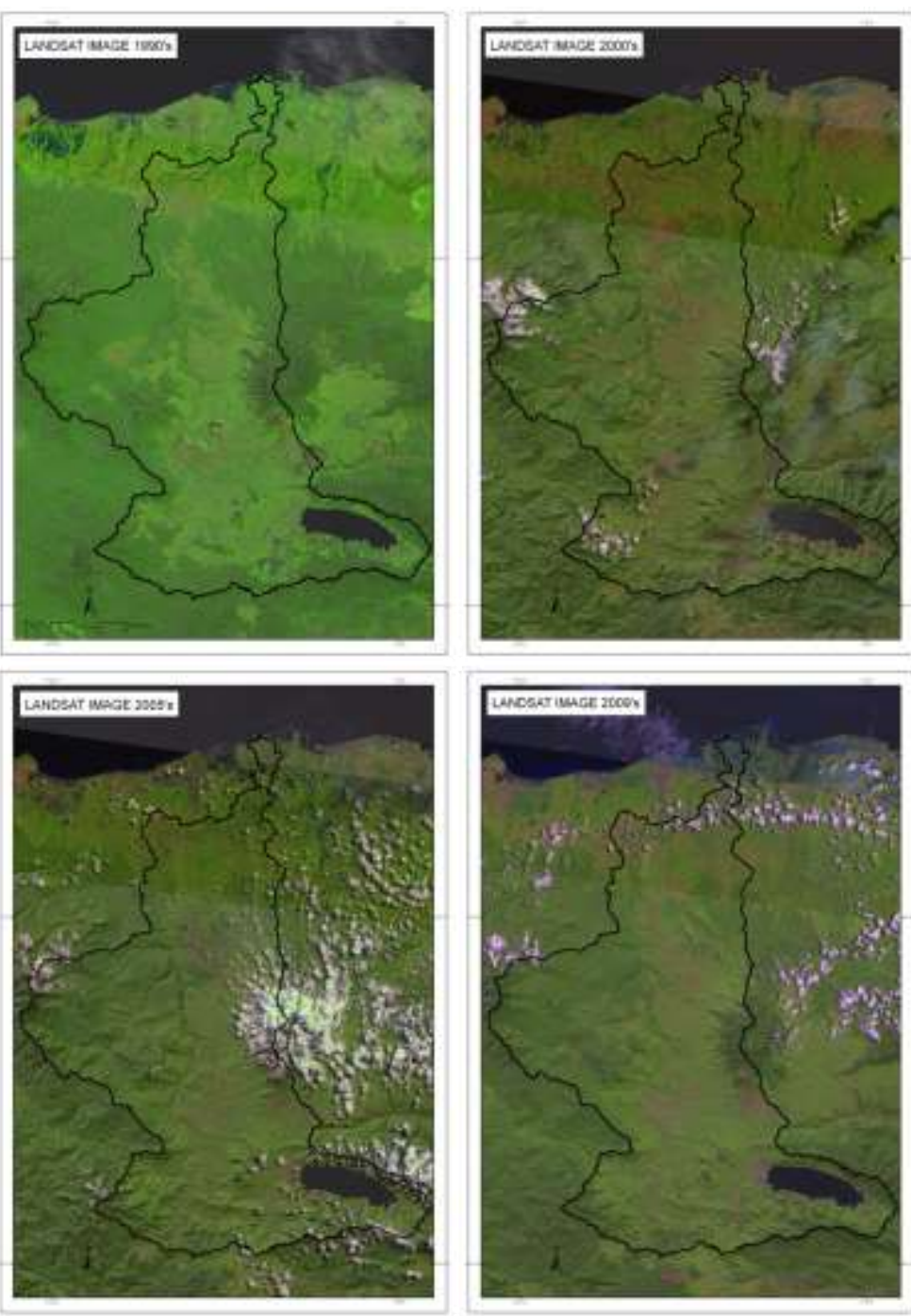

Figure 3. Time series satellite image for the Krueng Peusangan watershed 


\section{Digital elevation model}

Digital elevation model (DEM) provides information on elevation and topographic feature of a landscape. In RHA, we use the DEM to delineate watershed and catchment area. Shuttle Radar Topographic Mission (SRTM) data were used in this process.

\section{Thematic maps}

To further understand landscape configuration of the Krueng Peusangan watershed, datasets of thematic maps will be collected. The datasets consist of several maps: administrative boundary, soil, geology, land designation and land use planning.

\subsubsection{Terrain processing for watershed delineation}

The main objective of terrain processing in RHA is to delineate watershed boundary and identify stream network of the study area. SRTM digital elevation model in $90 \mathrm{~m}$ spatial resolution is the primary data for this process. We conducted terrain processing using ArcHydro (http://www.crwr.utexas.edu/giswr/hydro/ArcHOSS/index.cfm), a Geographical Information System (GIS) framework to model and analyze hydrological configuration for this purpose. Two main datasets that will be derived from this phase are watershed/catchment boundary delineation and routing distance of a stream to its outlet. The datasets will be used in GenRiver model to further understand hydrological process within study area. Terrain processing in ArcHydro consists of several processing steps as showed in Figure 4.

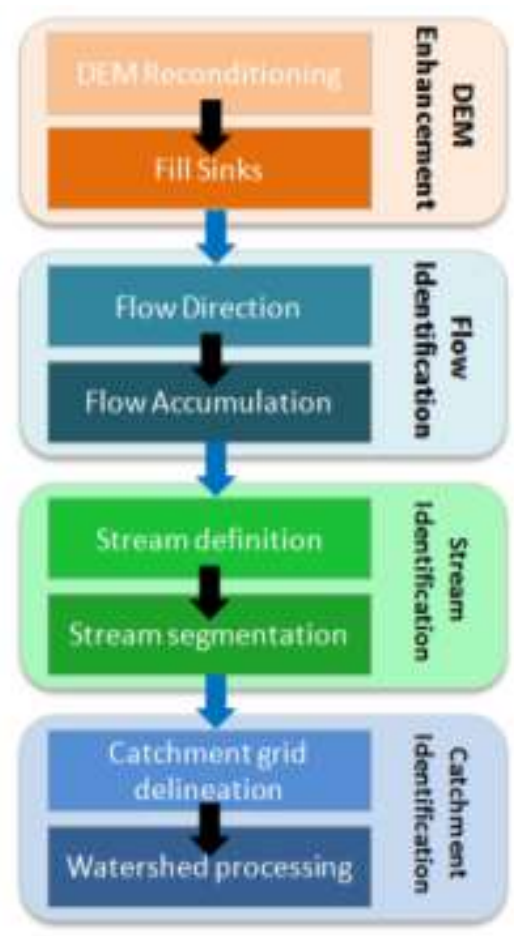

Figure 4. Overall workflow of terrain processing for watershed and stream network delineation 


\subsubsection{Analysis of land use/cover change and trajectories (ALUCT)}

Analysis of land use/cover changes and trajectories (ALUCT) is a framework used to understand the land use dynamics over a landscape using remote sensing data. For a RHA application, ALUCT will produce three main outputs:

1. Time series land cover maps from covering period of 1990's, 2000's, 2005's, and 2009's.

2. Land cover change quantification of study area

3. Land cover trajectories for the period of analysis

Two types of data are required to conduct ALUCT: (1) time series satellite image and (2) ground truth data collected from fieldwork. Landsat images in $30 \mathrm{~m}$ spatial resolution will be used in this phase, while ground truth data was collected during a fieldwork in January 2010.

Before ALUCT implementation, it is required to conduct inventories and to define classes of land use/cover in the study area. The classes are designed such that they are recognizable from the satellite imageries and they embrace all the dominant land-use/cover types that exist in the study area. A list of relevant land-use classes was developed through fieldwork in the study area.

ALUCT workflow (Figure 5) can be classified into three stages: (1) Image pre-processing, (2) Image classification, and (3) Post interpretation analysis. The first stage, Image pre-processing, aims to rectify geometric distortion in satellite images using ground control point (GCP) collected from reference datasets. In this case, orthorectified Landsat 1990 image from United States Geological Survey (USGS) is used as reference data. Minimum of $20 \mathrm{GCP}$ were used in geometric correction, ensuring geometric precision of $0.5 \operatorname{pixel}(<15 \mathrm{~m})$ for all images.

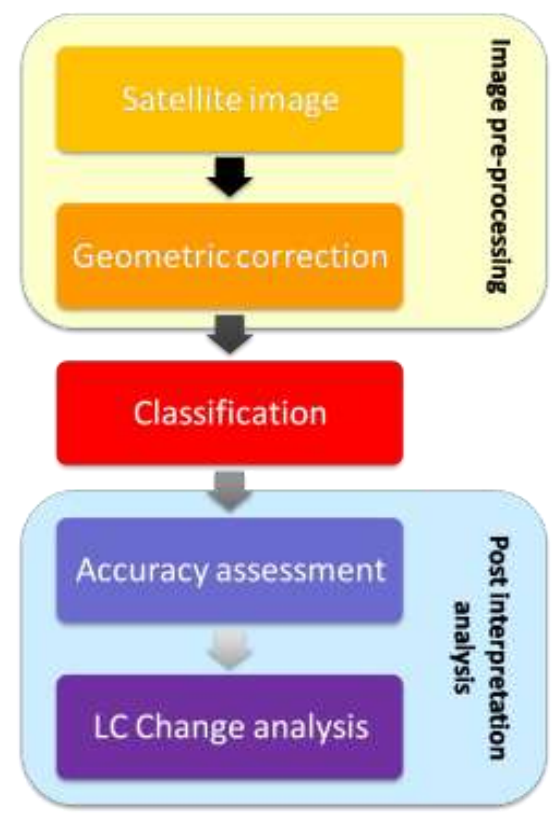

Figure 5. Overall work flow of analysis of land use/cover change and trajectories (ALUCT) 
The second stage of ALUCT is image classification. Its objective is to interpret spectral information contained in satellite image into land use classes. Object-based hierarchical classification approach is used in this stage. In this approach, image classification began with an image segmentation process. The purpose is to produce image objects, a group of pixels with a similar level of homogeneity in terms of spectral and spatial characteristics. Image objects have to be able to represent the actual landscape features in the satellite images. Several phases of segmentation were conducted to get the required levels of detail. The outputs of these phases are called multiresolution image segments, which serve as a basis for the hierarchical classification system. The segmentation processes are illustrated in Figure 6.

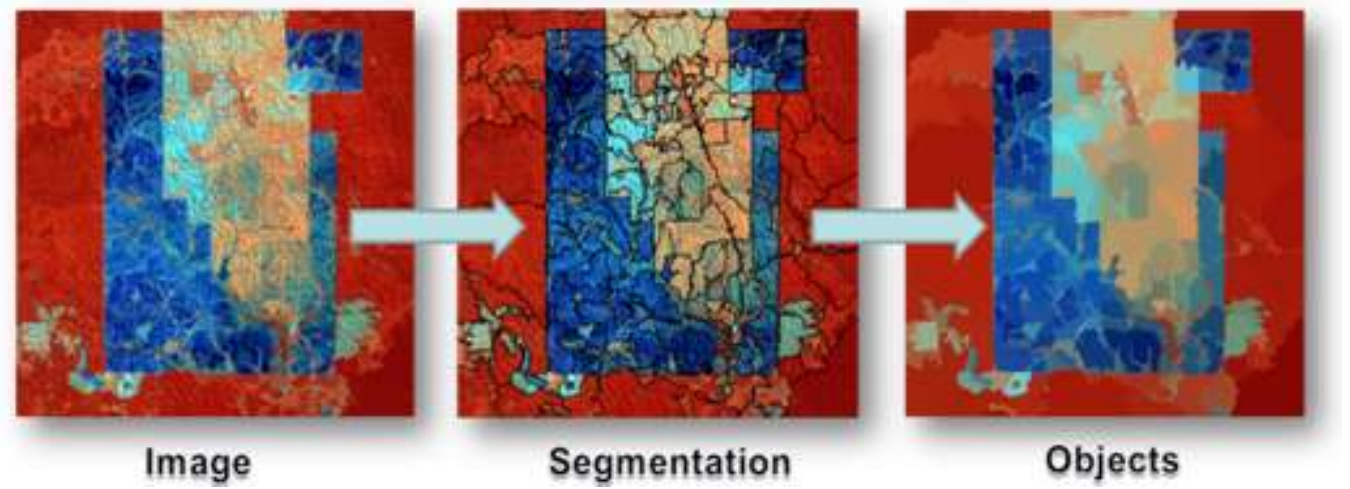

Figure 6. Segmentation process

Following the segmentation process, image classification was conducted using hierarchical structure showed in Figure 7. The hierarchy is divided into four levels, and in each level, land cover types are interpreted using spectral and spatial rules. Details and complexity of land cover types increasing in each level, therefore each of them has different set of rules applied. Level 1 consists of general classes such as: Forest, Tree-based system, Non tree based system and Non vegetation. These classes can be easily distinguished using visual inspections and simple vegetation index. Vegetation index is a ratio of spectral value between vegetation-sensitive channel (near infrared spectrum) and non vegetation-sensitive channel (visible spectrum) in satellite image.

Result of Level 1 is further classified in Level 2, in this level, spectral value is not the only parameters used, spatial characteristics such as oil palm map, field reference and Nearest Neighborhood algorithm was used as a rule in classification. Nearest Neighborhood algorithm in object-based hierarchical classification is conducted in two steps: (1) Feature space optimization, and (2) Classification (Definiens, 2007). The first step is conducted to calculate combination of object features that produces the largest average minimum distance between the samples of the different classes.

The combination of object features is used in the second steps to classify all objects into land cover classes in level 2. Level 2 consists of 10 land cover types: undisturbed forest, logged over forest, pine forest, agroforest, monoculture tree based system, shrub, cropland, grass, cleared land and settlement. Agroforest and monoculture tree based system are classified into coffee agroforest, mixed garden, oil palm and logged over pine in Level 3. 
Kombinasi cirri-ciri obyek digunakan pada tahap kedua untuk mengklasifikasikan obyek kedalam kelas tutupan lahan pada tingkat 2. Tingkat 2 mempuntai 10 kelas tutupan lahan: hutan tidak terganggu, hutan bekas tebangan, hutan pinus,

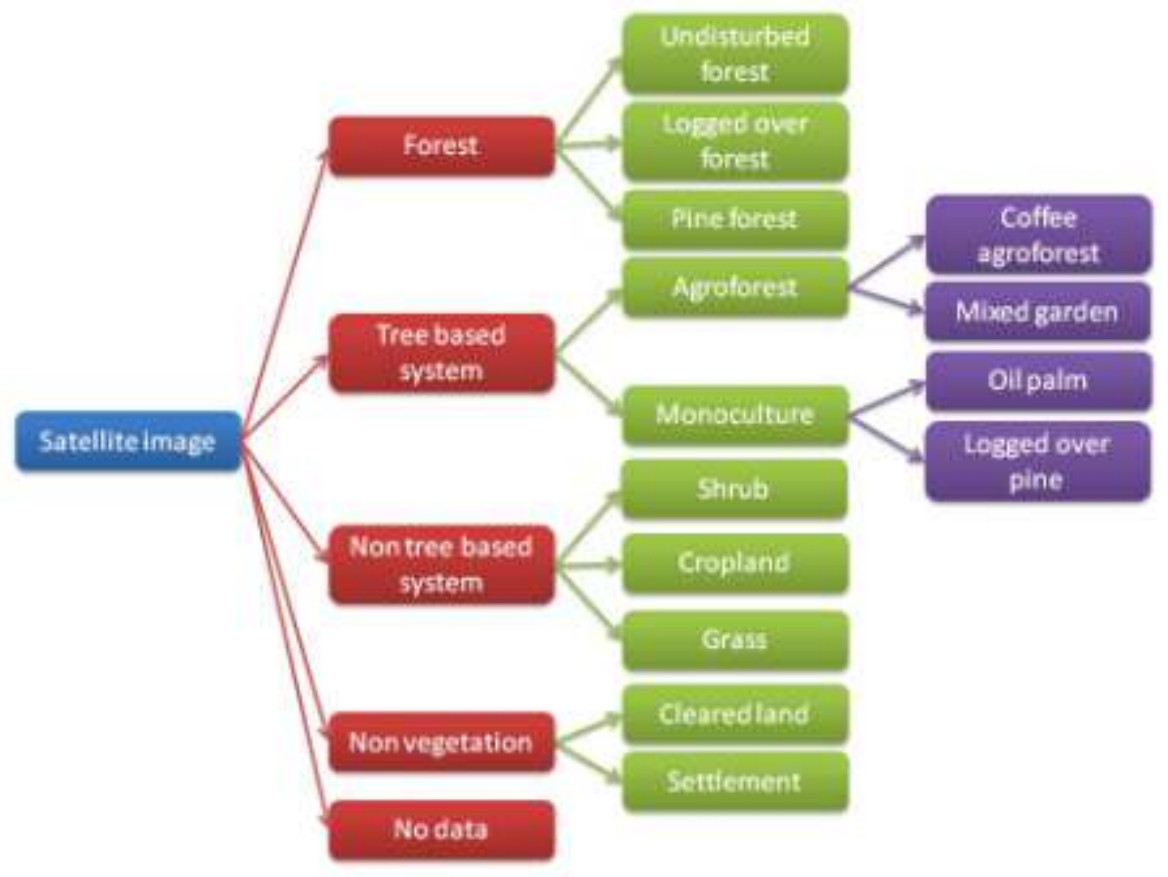

Figure 7. Classification hierarchical scheme

Image classification is followed by Post classification analysis process. It consists of two processes, accuracy assessment and land cover change analysis. The objective of accuracy assessment is to test the quality of information derived from image classification process. It is conducted by comparing field reference data with the most recent land cover map produced in each site. Minimum accuracy level should be above $80 \%$. The last step in ALUCT is the land cover change analysis.

Two form of land cover change analysis is conducted for each study site: area-based changes analysis and trajectories analysis. An area-based change is a simple analysis conducted by comparing total area of land cover types in each period. This analysis will conducted in 2 analysis windows: (1) catchment area of the Krueng Peusangan watershed and (2) administrative area within the Krueng Peusangan watershed. The result will show a clear indication of dominant type of land cover change in the study area. The last phase of ALUCT, trajectories analysis, is conducted to spatially assess trend of land use/cover change over the period of analysis.

\subsection{Analyses of the Consequences of Current and Future Land Cover Change on Water Balance Including River Flow}

A modeling approach is used to estimate the landscape water balance including river flow, using GenRiver 2.0 (Generic River flow) model (van Noordwijk et al., 2010). GenRiver 2.0 is a simple model that translates a plot-level water balance to landscape. The model can be used to explore the understanding of historical changes in river flow due to land cover/use change. 
As is common in hydrology, the accounting of rainfall or precipitation $(\mathrm{P})$ in the landscape include evapotranspiration, E; river discharge, $\mathrm{Q}$ (summed over base flow, soil quick flow and surface flow); and changes in soil and groundwater storage, $\Delta \mathrm{S}$ (Figure 8).

$$
\mathrm{P}=\mathrm{Q}+\mathrm{E}+\Delta \mathrm{S}
$$

The core of the GenRiver 2.0 model is a 'patch' level representation of a daily water balance, driven by local rainfall and modified by the land cover and land cover change and soil properties of the patch. The patch can contribute to three types of stream flow: surface-quick flow on the day of the rainfall event, soil-quick flow on the next day and base flow, via the gradual release of groundwater.

A river is treated as a summation of streams, each originating in a sub-catchment with its own daily rainfall, yearly land cover fractions and constant total area and distance to the river outflow (or measurement) point. Interactions between streams in their contribution to the river are considered to be negligible (i.e. there is no 'backflow' problem). Spatial patterns in daily rainfall events are translated into average daily rainfall in each sub-catchment. The sub-catchment model represents interception, infiltration into soil, rapid percolation into subsoil, surface flow of water and rapid lateral subsurface flow into streams with parameters that can vary between land cover classes (Figure 8).

The modeling activity was carried out using the following steps:

1. Data preparation and model parameterization;

2. Model calibration including evaluation on model performance;

3. Assessment of hydrological situation of watershed;

4. Scenario development based on result analysis of LEK and PEK (section 2.1)

5. Model simulation based on scenarios developed in point 4 to understand the impact of land use change on water balance and river flow.

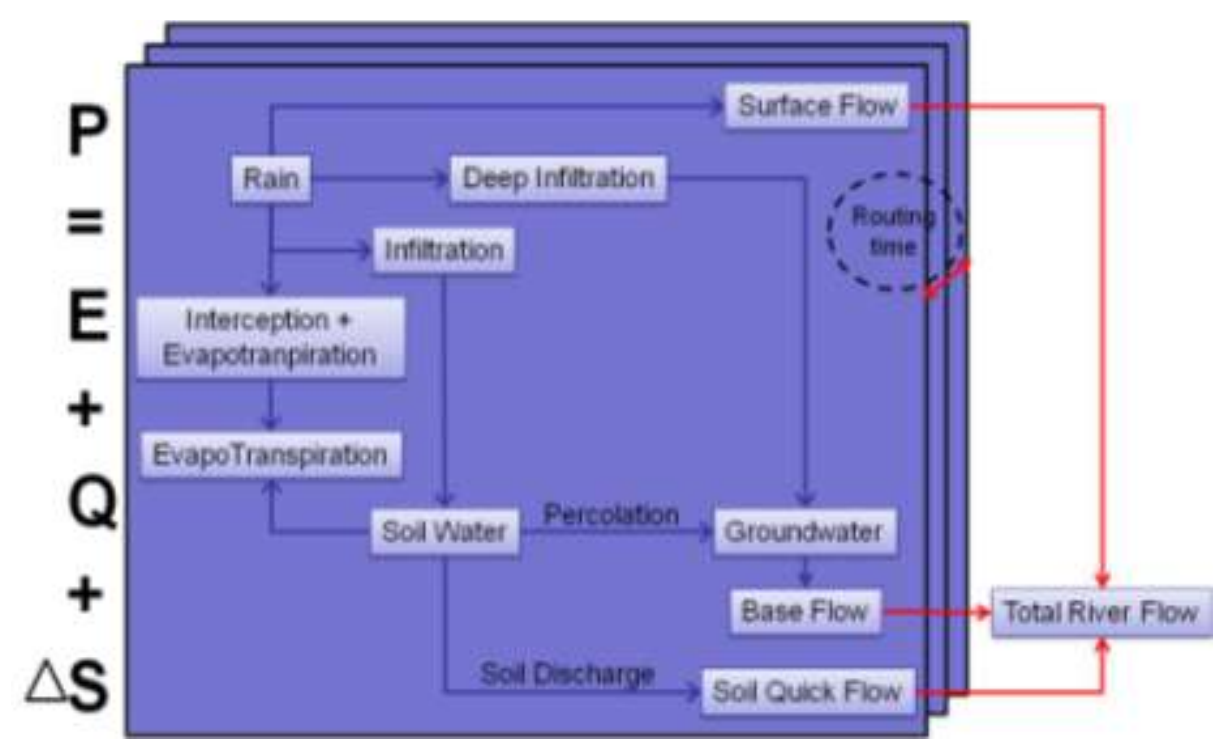

Figure 8. Overview of GenRiver 2.0 model 


\subsubsection{Model parameterization}

The data preparation for model parameterization including, analysis of climate (rainfall and evapotranspiration) and hydrology (discharge) data (Section 2.2); and processing spatial data: soil, land cover dynamic and watershed characteristic data (Section 2.3) (Table 4).

Table 4. Input data for GenRiver 2.0 model

\begin{tabular}{|c|c|c|c|}
\hline Data & & Source & GenRiver Parameterization \\
\hline \multirow[t]{2}{*}{$\begin{array}{l}\text { 1. Climate } \\
\text { data }\end{array}$} & $\begin{array}{l}\text { Daily rainfall for } 20 \text { years (1990 - } \\
\text { 2009) }\end{array}$ & $\begin{array}{l}\text { Climatology station } \\
\text { and worldlim }\end{array}$ & Input data \\
\hline & $\begin{array}{l}\text { Supporting data (monthly } \\
\text { averaged evapotranspiration) for } \\
10 \text { years }(2000-2009)\end{array}$ & & Input data \\
\hline $\begin{array}{l}\text { 2. Discharge } \\
\text { data }\end{array}$ & $\begin{array}{l}\text { Daily discharge data for } 7 \text { years } \\
(1991 \text { - 1997) }\end{array}$ & River station & Model calibration \\
\hline \multirow[t]{5}{*}{$\begin{array}{l}\text { 3. Spatial } \\
\text { data }\end{array}$} & $\begin{array}{l}\text { Soil depth and type for } 11 \text { sub- } \\
\text { catchment }\end{array}$ & Existing soil maps & $\begin{array}{ll}\text { - } & \text { Input data } \\
\text { - } & \text { Generating others input data }\end{array}$ \\
\hline & $\begin{array}{l}\text { Land cover map at year } 1990 \text {, } \\
2000,2005 \text { and } 2009\end{array}$ & $\begin{array}{l}\text { Image } \\
\text { interpretation }\end{array}$ & Input data \\
\hline & $\begin{array}{l}\text { Land cover dynamic at the time } \\
\text { series }\end{array}$ & $\begin{array}{l}\text { Image } \\
\text { interpretation }\end{array}$ & Input data \\
\hline & $\begin{array}{l}\text { Catchment and } 11 \text { sub-catchment } \\
\text { boundary }\end{array}$ & DEM & Input data \\
\hline & $\begin{array}{l}\text { Distance to outlet (routing } \\
\text { distance) for } 11 \text { sub-catchment }\end{array}$ & & Input data \\
\hline $\begin{array}{l}\text { 4. Supporting } \\
\text { data }\end{array}$ & Lake volume & Local exploration & $\begin{array}{l}\text { Storage volume, inflow and } \\
\text { outflow }\end{array}$ \\
\hline
\end{tabular}

Prior to the use of rainfall and discharge data as an input and validation model, daily rainfall data that cover the Krueng Peusangan watershed was generated using rainfall simulator model (Table 19) and a series of fine-tuning data of discharge need to be done in order to get a good quality data (Figure 16 and 17). Monthly average of potential evapotranspiration was calculated based on 2000 2009 available data (Figure 11). Daily pattern of potential evapotranspiration of each land cover type was calculated by multiplying this monthly value to multiplier of each land cover type (Table $5)$.

Table 5. Multiplier of daily potential evapotranspiration for each land cover type

\begin{tabular}{lcccccccccccc}
\hline \multirow{2}{*}{ Land cover type } & \multicolumn{10}{c}{ Multiplier of Daily Potential Evapotranspiration } \\
\cline { 2 - 14 } & Jan & Feb & Mar & Apr & May & Jun & Jul & Aug & Sep & Oct & Nov & Dec \\
\hline Forest & 0.80 & 0.80 & 0.80 & 0.80 & 0.80 & 0.80 & 0.80 & 0.80 & 0.80 & 0.80 & 0.80 & 0.80 \\
\hline Logged over forest & 0.50 & 0.50 & 0.50 & 0.50 & 0.50 & 0.50 & 0.50 & 0.50 & 0.50 & 0.50 & 0.50 & 0.50 \\
\hline Pine forest & 1.00 & 1.00 & 1.00 & 1.00 & 1.00 & 1.00 & 1.00 & 1.00 & 1.00 & 1.00 & 1.00 & 1.00 \\
\hline Logged over pine & 0.80 & 0.80 & 0.80 & 0.80 & 0.80 & 0.80 & 0.80 & 0.80 & 0.80 & 0.80 & 0.80 & 0.80 \\
\hline Oil palm & 0.50 & 0.50 & 0.50 & 0.50 & 0.50 & 0.50 & 0.50 & 0.50 & 0.50 & 0.50 & 0.50 & 0.50 \\
\hline Complex mixed tree crop & 0.70 & 0.70 & 0.70 & 0.70 & 0.70 & 0.70 & 0.70 & 0.70 & 0.70 & 0.70 & 0.70 & 0.70 \\
\hline Monoculture tree & 0.50 & 0.50 & 0.50 & 0.50 & 0.50 & 0.50 & 0.50 & 0.50 & 0.50 & 0.50 & 0.50 & 0.50 \\
\hline Horticulture & 1.00 & 1.00 & 1.00 & 1.00 & 1.00 & 1.00 & 0.70 & 0.30 & 0.50 & 0.50 & 0.50 & 0.80 \\
\hline Rice field & 1.00 & 1.00 & 1.00 & 1.00 & 1.00 & 1.00 & 1.00 & 1.00 & 1.00 & 1.00 & 1.00 & 1.00 \\
\hline Shrub and grass & 0.60 & 0.60 & 0.60 & 0.60 & 0.60 & 0.60 & 0.60 & 0.60 & 0.60 & 0.60 & 0.60 & 0.60 \\
\hline Settlement & 0.00 & 0.00 & 0.00 & 0.00 & 0.00 & 0.00 & 0.00 & 0.00 & 0.00 & 0.00 & 0.00 & 0.00 \\
\hline
\end{tabular}


Ultisols and Inceptisols are major soil type in all sub-catchment (Table 6) with low infiltration rate compared to other soil types. It is more than $80 \%$ of the total area. The average of soil BD/BDref is range 0.8 (forest) -1.3 (settlement) (Table 8).

Table 6. Soil type, area and distance to outlet for each sub-catchment

\begin{tabular}{|c|c|c|c|c|c|c|c|c|}
\hline \multicolumn{2}{|c|}{ Sub-catchment } & \multirow{2}{*}{$\begin{array}{c}\begin{array}{c}\text { Area } \\
\left(\mathbf{k m}^{2}\right)\end{array} \\
135.79\end{array}$} & \multirow{2}{*}{$\begin{array}{c}\begin{array}{c}\text { Distance } \\
\text { to final } \\
\text { outlet } \\
\text { (km) }\end{array} \\
91.71\end{array}$} & \multirow{2}{*}{$\begin{array}{r}\text { Alfisols } \\
0.00\end{array}$} & \multirow{2}{*}{$\begin{array}{c}\text { Entisols } \\
0.00\end{array}$} & \multirow{2}{*}{$\begin{array}{c}\text { Inceptisols } \\
9.34\end{array}$} & \multirow{2}{*}{$\begin{array}{c}\text { Mollisols } \\
0.00\end{array}$} & \multirow{2}{*}{$\begin{array}{r}\text { Ultisols } \\
90.66\end{array}$} \\
\hline Down- & LC1 & & & & & & & \\
\hline stream & LC2 & 305.44 & 63.68 & 0.00 & 0.00 & 42.38 & 0.00 & 57.62 \\
\hline & LC3 & 185.71 & 73.96 & 0.00 & 0.00 & 63.07 & 0.00 & 36.93 \\
\hline & LC4 & 67.22 & 23.77 & 0.00 & 0.09 & 66.06 & 0.00 & 33.85 \\
\hline \multirow{2}{*}{$\begin{array}{l}\text { Middle } \\
\text { stream }\end{array}$} & MC1 & 362.17 & 108.02 & 0.00 & 0.00 & 58.56 & 2.68 & 38.76 \\
\hline & MC2 & 324.68 & 101.80 & 0.00 & 0.00 & 15.09 & 14.05 & 70.86 \\
\hline \multirow[t]{5}{*}{ Upstream } & UC1 upper-part & 197.79 & 153.24 & 0.20 & 0.00 & 34.05 & 51.10 & 14.65 \\
\hline & UC1 lower-part & 192.43 & 126.81 & 0.20 & 0.00 & 34.05 & 51.10 & 14.65 \\
\hline & UC2 & 239.28 & 130.71 & 0.00 & 0.00 & 34.30 & 9.02 & 56.68 \\
\hline & UC3 & 137.46 & 119.93 & 0.00 & 0.00 & 63.87 & 0.00 & 36.13 \\
\hline & UC4 & 120.42 & 111.00 & 0.00 & 0.00 & 42.00 & 1.29 & 56.71 \\
\hline
\end{tabular}

The model run in 11 land cover types, therefore re-classification of land cover type of image analysis should be done prior to the use of data (Table 7). The re-classification is based on its potential interception and rank of soil bulk density (Table 8 ). For the last 20 years, forest type of cover $40 \%$ declined with mainly being converted into tree-based systems (Table 9).

Table 7. Land cover re-classification

\begin{tabular}{|c|c|c|}
\hline No. & Land cover type of image analysis & Land cover type of GenRiver model \\
\hline 1. & Undisturbed forest & Forest \\
\hline 2. & Logged over forest & Logged over forest \\
\hline 3. & Pine forest & Pine forest \\
\hline 4. & Logged over pine & Logged over pine \\
\hline 5. & Oil palm & Oil palm \\
\hline 6. & Mixed garden & \multirow{3}{*}{ Complex mixed tree crop } \\
\hline 7. & Coconut agroforest & \\
\hline 8. & Coffee agroforest & \\
\hline 9. & Areca catechu (pinang) monoculture & \multirow{3}{*}{ Monoculture tree } \\
\hline 10. & Rubber monoculture & \\
\hline 11. & Metroxylon sago (sagu) monoculture & \\
\hline 12. & Cropland & Horticulture \\
\hline 13. & Rice field & Rice field \\
\hline 14. & Shrub & \multirow{3}{*}{ Shrub and grass } \\
\hline 15. & Grassland & \\
\hline 16. & Cleared land & \\
\hline 17. & Settlement & Settlement \\
\hline
\end{tabular}

Based on result of delineation of watershed and catchment area using DEM, the Krueng Peusangan watershed consists of 11 sub-watersheds (Figure 18). Table 6 presented the area of each subwatershed and its distance to outlet. The lake air tawar occupied the upper part of the upstream area.

A number of non-measured parameters were used during model calibration process. The parameters include potential canopy interception, relative drought threshold per land cover type (Table 8) and a number of the catchment response parameters such as rainfall intensity and maximum infiltration rate (Table 10). 
Table 8. Input parameter BD/BDref, potential interception and relative drought Threshold

\begin{tabular}{lccc}
\hline \multicolumn{1}{c}{ Land cover type } & Potential Interception $\left(\mathbf{m m ~ d a y}^{-1}\right)$ & Relative Drought Threshold & BD/BDref \\
\hline Forest & 4.00 & 0.40 & 0.80 \\
\hline Logged over forest & 3.00 & 0.50 & 1.08 \\
\hline Pine forest & 5.00 & 0.40 & 1.15 \\
\hline Logged over pine & 3.50 & 0.40 & 1.10 \\
\hline Oil palm & 5.00 & 0.55 & 1.08 \\
\hline Complex mixed tree crop & 3.00 & 0.60 & 1.00 \\
\hline Monoculture tree & 4.00 & 0.55 & 1.08 \\
\hline Horticulture & 3.00 & 0.70 & 1.10 \\
\hline Rice field & 4.00 & 0.90 & 1.20 \\
\hline Shrub and grass & 2.00 & 0.55 & 1.00 \\
\hline Settlement & 0.05 & 0.01 & 1.30 \\
\hline
\end{tabular}

Table 9. Presentation of land cover change

\begin{tabular}{lrrrr}
\hline \multirow{2}{*}{ Land cover class } & \multicolumn{4}{c}{ Land cover change (all sub catchment) } \\
\cline { 2 - 5 } & $\mathbf{1 9 9 0}$ & $\mathbf{2 0 0 0}$ & $\mathbf{2 0 0 5}$ & $\mathbf{2 0 0 9}$ \\
\hline Forest & 39.66 & 26.06 & 23.55 & 22.21 \\
\hline Logged over forest & 12.54 & 15.19 & 14.85 & 14.89 \\
\hline Pine forest & 0.29 & 1.23 & 0.40 & 0.18 \\
\hline Logged over pine & 1.87 & 1.41 & 1.18 & 1.62 \\
\hline Oil palm & 0.00 & 0.00 & 1.05 & 2.98 \\
\hline Complex mixed tree crop & 27.82 & 36.51 & 44.83 & 43.72 \\
\hline Monoculture tree & 1.52 & 1.57 & 2.42 & 3.00 \\
\hline Horticulture & 9.27 & 3.62 & 3.42 & 3.55 \\
\hline Rice field & 3.05 & 3.70 & 2.13 & 2.57 \\
\hline Shrub and grass & 3.93 & 10.63 & 5.97 & 4.76 \\
\hline Settlement & 0.04 & 0.08 & 0.19 & 0.52 \\
\hline Total & 100 & 100 & 100 & 100 \\
\hline
\end{tabular}

Table 10. A number of non measured parameters

\begin{tabular}{lccc}
\hline \multicolumn{1}{c}{ Acronym $^{*}$} & Default & Value & Unit \\
\hline RainInterceptDripRt (i) & 10 & 30 & $\mathrm{~mm}$ \\
\hline RainMaxIntDripDur (i) & 0.5 & 0.7 & $\mathrm{~mm}$ \\
\hline InterceptEffectontrans(i) & 0.8 & 0.4 & $\mathrm{~mm}^{-1}$ \\
\hline RainIntensMean & 30 & 30 & $\mathrm{~mm} \mathrm{day}^{-1}$ \\
\hline RainIntensCoefVar & 0.3 & 0.35 & - \\
\hline MaxInfRate (i) & 720 & 400 & $\mathrm{~mm} \mathrm{day}^{-1}$ \\
\hline MaxInfSubsoil (i) & 120 & 100 & $\mathrm{~mm} \mathrm{day}^{-1}$ \\
\hline PerFracMultiplier (i) & 0.1 & 0.5 & - \\
\hline MaxDynGrWatStore (i) & 300 & 300 & $\mathrm{~mm}^{-}$ \\
\hline GWReleaseFracVar (i) & 0.1 & 0.03 & - \\
\hline Tortuosity (i) & 0.5 & 0.6 & - \\
\hline Dispersal Factor (i) & 0.5 & 0.6 & - \\
\hline River Velocity (i) & 0.4 & 0.7 & $\mathrm{~m} \mathrm{~s}^{-1}$ \\
\hline Initial Lake Volum & & & $\mathrm{m}^{3}$ \\
\hline
\end{tabular}

${ }^{*}$ More detail definition of each parameter is list in Appendix 1 of GenRiver model manual

\subsubsection{Model calibration and evaluation on model performance}

Statistical indicators proposed by Nash and Sutcliffe (1970) (Appendix 2), coefficient correlation (Appendix 1) and double mass cumulative rainfall - river flow curve are used for checking the performance of the model. Model performance was evaluated by comparing measured to simulated discharge. 


\subsubsection{Assessment of hydrological situation of watershed}

The assessment of hydrological situation of watershed is determined by the criteria and indicators of water transmission (total water yield per unit rainfall), buffering capacity (relationship of peak river flow and peak rainfall, linked to flooding risk) and gradual release of (ground) water in the dry season, based on recharge in the rainy season (Appendix 3). These indicators all relate the flows of water to the preceding rainfall and by doing so; allow the analysis of the relatively small land use effects, superimposed on substantial year-to-year variation in rainfall.

\subsubsection{Model simulation based on scenarios}

Once the model produces satisfactory output, we explored five scenarios for 10 years period of simulation (Table 11). The scenarios was resulted based on (1) the observations made during the LEK and PEK survey; (2) local community and stakeholder perception on the causal factor of hydrological problems; and (2) spatial data analysis and GenRiver model calibration and validation that proved the decreasing of tree cover increases the total water yield as a fraction of total rainfall. The scenarios focus on increasing tree based system in the landscape. The proportion of land use change for each scenario was presented in Table 12

Table 11. Scenarios to understand the impact of land use change

\begin{tabular}{cl}
\hline Scenarios & \multicolumn{1}{c}{ Description } \\
\hline BAU & Deforestation about 4\% of total area \\
\hline 1 & $\begin{array}{l}\text { Grassland, cleared land, shrub, cropland and rice field in all sub-catchments were } \\
\text { converted to complex mixed tree crop. }\end{array}$ \\
\hline 2 & Logged over forest in all sub-catchments were converted to pine forest. \\
\hline 3 & Scenario 1 + 2 \\
& $\begin{array}{l}\text { Cropland, rice field and monoculture tree (Areca catechu/betel nut and Metroxylon } \\
\text { sago/sagoo) in all sub-catchments were converted to complex mixed tree crop. } \\
\text { Grassland, cleared land, shrub, logged over pine and logged over forest in all sub- } \\
\text { catchments were converted to forest. }\end{array}$ \\
\hline 5 & $\begin{array}{l}\text { Full natural forest cover in all sub catchments except for settlements (historical } \\
\text { reference, potential endpoint of best practice forest restoration) }\end{array}$ \\
\hline
\end{tabular}

Table 12. Percentage of land cover change for each scenario

\begin{tabular}{lrrrrrrr}
\hline \multirow{2}{*}{ Land cover class } & \multicolumn{7}{c}{ Land cover change (all sub catchment) $^{*}$} \\
\cline { 2 - 7 } & $\mathbf{2 0 0 9}$ & BAU & $\mathbf{1}$ & $\mathbf{2}$ & $\mathbf{3}$ & $\mathbf{4}$ & $\mathbf{5}$ \\
\hline Forest & 22.21 & 18.16 & 22.21 & 22.21 & 22.21 & 43.48 & 99.48 \\
\hline Logged over forest & 14.89 & 18.94 & 14.89 & 0.00 & 0.00 & 0.00 & 0.00 \\
\hline Pine forest & 0.18 & 0.18 & 0.18 & 15.07 & 15.07 & 0.18 & 0.00 \\
\hline Logged over pine & 1.62 & 1.62 & 1.62 & 1.62 & 1.62 & 0.00 & 0.00 \\
\hline OilPalm & 2.98 & 2.98 & 2.98 & 2.98 & 2.98 & 2.98 & 0.00 \\
\hline Complex mixed tree crop & 43.72 & 43.72 & 54.60 & 43.72 & 54.60 & 51.13 & 0.00 \\
\hline Monoculture tree & 3.00 & 3.00 & 3.00 & 3.00 & 3.00 & 1.71 & 0.00 \\
\hline Horticulture & 3.55 & 3.55 & 0.00 & 3.55 & 0.00 & 0.00 & 0.00 \\
\hline Rice field & 2.57 & 2.57 & 0.00 & 2.57 & 0.00 & 0.00 & 0.00 \\
\hline Shrub and grass & 4.76 & 4.76 & 0.00 & 4.76 & 0.00 & 0.00 & 0.00 \\
\hline Settlement & 0.52 & 0.52 & 0.52 & 0.52 & 0.52 & 0.52 & 0.52 \\
\hline Total & 100 & 100 & 100 & 100 & 100 & 100 & 100 \\
\hline$*$
\end{tabular}

* red font: the area is decrease, blue font: the area is increase and black font: the area is remain the same compare to the 2009 


\section{Result}

\subsection{The Study Site}

\subsubsection{The Area}

Geographically, the Krueng Peusangan watershed is situated between latitude $5.27839-4.51068$ and longitude 96.4509 - 97.0476. The total area of the Krueng Peusangan watershed is about 2268.4 $\mathrm{km}^{2}$ covering four districts: upstream area in Aceh Tengah district, middle stream area in Bener Meriah district, and downstream area in Bireun and Aceh Utara district (Figure 9). It is consist of 11 sub-watersheds and Lake Laut Tawar $\left(5887 \mathrm{~m}^{2}\right)$ occupied the upper part of the watershed.

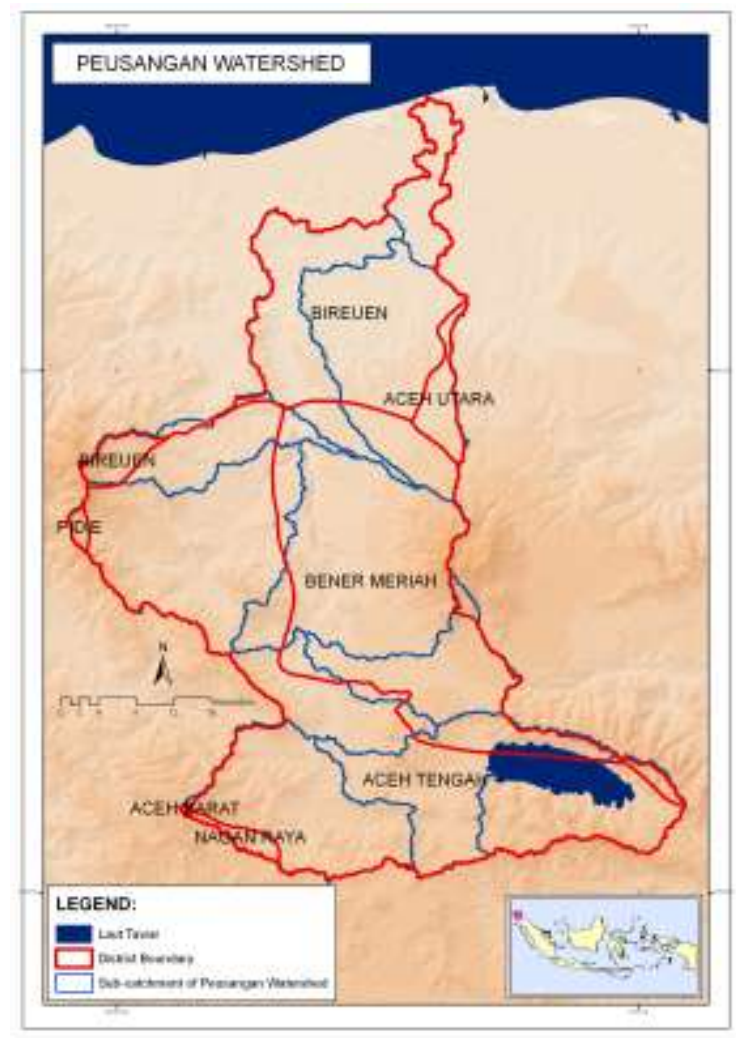

Figure 9. Study area of the Krueng Peusangan watershed

Based on rainfall data from www.worldclim.com for the period 1950 - present, the annual rainfall in the Krueng Peusangan watershed varies between $1848-2055 \mathrm{~mm}^{-{ }^{-1}}$ (Figure 10). Rainfall is distributed with a peak season in October - January and a dry season in June - August. The monthly average of potential evapotranspiration presented in Figure 11 with has a total amount of $1743 \mathrm{~mm}$ year ${ }^{-1}$.

The soil types in the Krueng Peusangan watershed are Alfisols, Entisols, Inseptisols, Ultisols, and Mollisols. Ultisols and Inceptisols are the two major soil types in all sub catchment. 

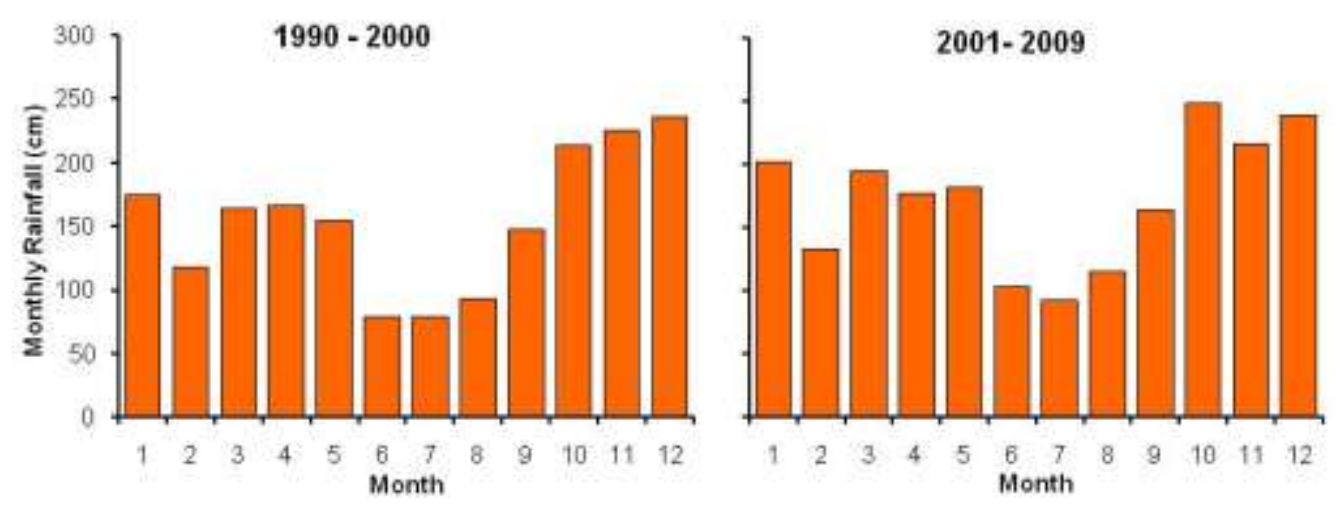

Figure 10. Monthly rainfall pattern in the Krueng Peusangan watershed (www.worldclim.com)

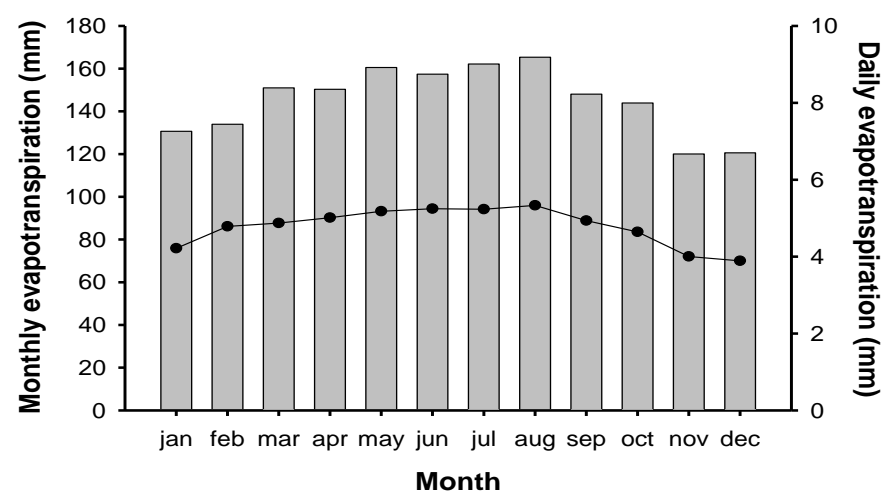

Figure 11. Monthly and daily evapotranpiration in the Krueng Peusangan watershed

\subsubsection{Community Characteristics}

The perceptions on watershed function and hydrological problems of local community members are vary from place to place. The perceptions appear to be connected to physical environmental condition, socio cultural characteristics as well as village history.

We classified the community groups living along the Krueng Peusangan watershed into three categories as describe in Table 13 in order to get a more comprehensive story and perspective of local community on watershed function and hydrological problems. Upstream communities (Gayo ethnicity) consist of: (1) community living along the river and (2) community living surround Lake Laut Tawar; and (3) communities living in down to middle part of watershed, down - midstream communities (Aceh ethnicity).

People in down - midstream area are practicing irrigated paddy system and mixed garden system. The main commodities of mixed garden system are coconut (Cocos nucifera), oil palm (Elais guinensis), and some fruit trees (Table 14). Further to upstream, mixed garden systems perform more complex with pinang (Areca catechu), coffee (Coffee sp.) and cocoa (Theobroma cacao) as the main trees incorporate with some fruit trees. Lamtoro (Leucaena leucocephala), Pete (Parkia perkinensis), avocado (Persea americana Mill), terong belanda (Cyphomadra betake) and chilly (Capsicum sp.) are the main valuable trees and crops incorporate within coffee system in surrounding Lake Laut Tawar. 
Irrigated paddy systems planted twice a year are very important for both subsistence and commercial purposes in all sub-catchment. In some downstream area, particularly nearby the 'kuala' or estuaria, instead of paddy systems there are 'tambak' or fishpond system with main products are udang windu (Penaeus monodon), bandeng (Chanos chanos Forskal) and Nila (Oreochromis sp.).

Table 13. Community characteristics

\begin{tabular}{|c|c|c|c|}
\hline & Down - midstream & Upstream along the river & $\begin{array}{l}\text { Upstream surrounding } \\
\text { lake }\end{array}$ \\
\hline Area & $\begin{array}{l}\text { Kota Lhokseumawe, Kabupaten } \\
\text { Bireun, Kabupaten Aceh Utara }\end{array}$ & Kabupaten Bener Meriah & Kabupaten Aceh Tengah \\
\hline $\begin{array}{l}\text { Related } \\
\text { watershed }\end{array}$ & $\begin{array}{l}\text { Krueng Peusangan } \\
\text { Krueng Mane }\end{array}$ & $\begin{array}{l}\text { Krueng Peusangan, Krueng } \\
\text { Jambo Aye, Krueng Pase, } \\
\text { Krueng Mane dan Krueng } \\
\text { Keureutoe }\end{array}$ & Krueng Peusangan \\
\hline $\begin{array}{l}\text { Community } \\
\text { characteristics }\end{array}$ & Fishing and farming community & \multicolumn{2}{|c|}{ Farming - mixed garden community } \\
\hline $\begin{array}{l}\text { Livelihood } \\
\text { source }\end{array}$ & $\begin{array}{ll}\text { - } & \text { Paddy production (twice } \\
& \text { per year) } \\
\text { - } & \text { Coconut production } \\
\text { - } & \text { Fishing (subsistence need } \\
\text { from the river, on the sea } \\
\text { for commercial purpose) }\end{array}$ & $\begin{array}{ll}\text { - } & \text { Paddy production (twice } \\
& \text { per year) } \\
\text { - } & \text { Pinang } \\
\text { - } & \text { Coffee and cocoa } \\
& \text { production }\end{array}$ & 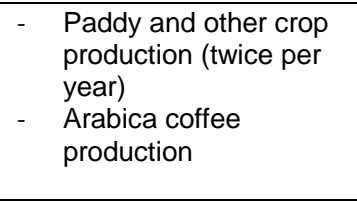 \\
\hline $\begin{array}{l}\text { Riparian } \\
\text { vegetation }\end{array}$ & $\begin{array}{l}\text { Bamboo, Grass, Waru } \\
\text { (Hibiscus tiliaceus L), Jaloh } \\
\text { (Salix tetrasperma Roxb) }\end{array}$ & Grass, Waru & $\begin{array}{l}\text { Paddy, coffee and tobacco } \\
\text { (Nicotiana tabacum) }\end{array}$ \\
\hline Ethnic & Aceh & Gayo & Gayo \\
\hline Water source & & Ground and surface water & \\
\hline
\end{tabular}

Table 14. Riparian land use area in down to midstream

\begin{tabular}{|c|c|c|c|c|c|}
\hline Land use & Irrigated paddy & $\begin{array}{l}\text { Settlement area, } \\
\text { homegarden }\end{array}$ & $\begin{array}{l}\text { Mixed } \\
\text { Garden }\end{array}$ & $\begin{array}{l}\text { Fishpond } \\
\text { (tambak) }\end{array}$ & River \\
\hline $\begin{array}{l}\text { Water } \\
\text { sourco }\end{array}$ & $\begin{array}{l}\text { Techricel } \\
\text { imgatica, semi } \\
\text { technical from } \\
\text { fiver }\end{array}$ & Rivec, ground water & River & $\begin{array}{l}\text { Technital } \\
\text { imigetion }\end{array}$ & $\begin{array}{l}\text { Simple } \\
\text { itngation }\end{array}$ \\
\hline Vegetation & Paddy & Horticulture & $\begin{array}{l}\text { Coconid. } \\
\text { Benena, } \\
\text { Caliandra, } \\
\text { Casava, } \\
\text { Mixed Frut, } \\
\text { Pinang }\end{array}$ & & $\begin{array}{l}\text { Ripanan } \\
\text { vegetetion } \\
\text { Bamboo. } \\
\text { waru, jelon }\end{array}$ \\
\hline $\begin{array}{l}\text { Land } \\
\text { ownership }\end{array}$ & Imbividus: & indiviess! & Individuas: & Indvidual & - \\
\hline Fauna & Bird, rat & Squirre, Rat, Bird & Squirrel & $\begin{array}{l}\text { Udang } \\
\text { Winde (giant } \\
\text { shrimp). } \\
\text { Banderg. } \\
\text { crabs and } \\
\text { Ikan Wila. }\end{array}$ & Fish \\
\hline
\end{tabular}

Floating net culture is important livelihood source for communities living in the mid - upstream of the Krueng Peusangan watershed as well as in Lake Laut Tawar area (Table 15). Nearly $40 \%$ of people living in those areas are relying on fishery sectors in the river as well as attached in lake area. 
Kawan (Poropuntius tawarensis), peres (Osteochilus kahayensis), mud (Clarias batrachus), pedih (Neolissochilus sp), gegaring (Tor sp) and depik (Rasbora tawarensis) are some native species commonly found in Lake Laut Tawar. Depik is considered as critical endangered species with populations decreasing in recent years. In 1996, the IUCN assessed this species as "vulnerable" in red list category. Lele dumbo (Clarias gariepinus), ikan mas (Cyprinus carpio), mujair (Oreochromis mossambicus), nila (O. niloticus) and grass carp (Ctenopharyngodon idella) (Muchlisin, 2008) are the introduction species that were cultivated using floating net culture and pen culture (kolam tancap).

Table 15. Land use in surrounding Lake Laut Tawar

\begin{tabular}{|c|c|c|c|c|c|}
\hline Land uas & Pine forest & Mixed garden & $\begin{array}{l}\text { Settiement, } \\
\text { homergarden }\end{array}$ & $\begin{array}{l}\text { Irrigated paddy } \\
\text { (horticulture) }\end{array}$ & Lake \\
\hline $\begin{array}{l}\text { Water } \\
\text { source }\end{array}$ & - & Ran water & $\begin{array}{l}\text { River, ground } \\
\text { woter }\end{array}$ & River & \\
\hline Vegetation & Pino & $\begin{array}{l}\text { Coftee, fobacco, } \\
\text { grocado, pala, } \\
\text { rambutan, rubber. } \\
\text { dirien }\end{array}$ & Horticulure & $\begin{array}{l}\text { Peddy. vegetables, } \\
\text { cassava }\end{array}$ & \\
\hline Topography & $30-45$ degree & $30-45$ degree & Slope & Flat & \\
\hline $\begin{array}{l}\text { Land } \\
\text { ownership }\end{array}$ & State land & Not clear & Individual & Individual & \\
\hline Fauna & Squirres & Squirrel & Rat & Rat & $\begin{array}{l}\text { Derik, } \\
\text { Pedin, } \\
\text { Gasous, Lele }\end{array}$ \\
\hline
\end{tabular}

\subsection{Knowledge Surveys and Stakeholder Analysis}

\subsubsection{Knowledge and perspective of local community on hydrological problems}

Knowledge surveys resulted on the importance of watershed functions and hydrology problems for different community groups. Both downstream and upstream communities considered that the river is an important not only as a source of water for drinking and cooking, to irrigate their paddy fields, but also as a source of livelihood (fish production) (Table 16). The local communities living surrounding the Lake Laut Tawar mostly use the lake to cultivate fish (floating culture as well as fishpond) and a limited extent to irrigate their paddy field.

Group discussion identified some hydrological problems faced by the community and possible solution based on local perception and knowledge. Problems in down to midstream areas are abrasion and floods (Table 17). Communities in upstream found that decreasing river flow and sedimentation are important hydrological issues to be solved. People surrounding Lake Laut Tawar observed that sedimentation was the main problem. 
Table 16. Knowledge and perspective of local community on watershed functions

\begin{tabular}{|c|c|c|c|c|}
\hline \multirow{2}{*}{ Function } & \multicolumn{3}{|c|}{ River } & \multirow{2}{*}{ Lake Laut Tawar } \\
\hline & Downstream & Midstream & Upstream & \\
\hline Paddy field - water irrigation & **** & **** & 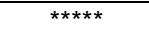 & *** \\
\hline Fishpond - water system & $* * \star$ & ** & $* * * *$ & 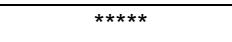 \\
\hline Sewage disposal & * & ** & ** & * \\
\hline Water for consumption & $* * * *$ & *** & 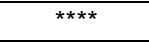 & ** \\
\hline Water for sanitation & 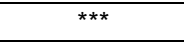 & *** & 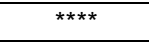 & * \\
\hline Galian C - sand mining & 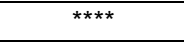 & **** & & \\
\hline Fishing & 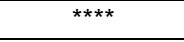 & *** & ** & *** \\
\hline Transportation & * & * & & \\
\hline Tourism attraction & * & * & & *** \\
\hline
\end{tabular}

Note: stars indicating level of importance of watershed function

Table 17. Knowledge and perspective of local community on hydrological problems

\begin{tabular}{lcccc}
\hline \multirow{2}{*}{ Main problems } & \multicolumn{3}{c}{ River } & \multirow{2}{*}{ Lake Laut tawar } \\
\cline { 2 - 4 } & Downstream & Midstream & Upstream & \\
\hline Abrasion & ${ }^{* * *}$ & ${ }^{* * * *}$ & ${ }^{*}$ & \\
\hline Flood & ${ }^{* * * *}$ & ${ }^{* * * *}$ & ${ }^{*}$ & \\
\hline River flow decreasing & ${ }^{*}$ & ${ }^{*}$ & ${ }^{* * * *}$ & ${ }^{*}$ \\
\hline Biodiversity & ${ }^{* *}$ & ${ }^{* *}$ & ${ }^{* *}$ & ${ }^{* *}$ \\
\hline Low quality of water & ${ }^{* *}$ & ${ }^{* *}$ & ${ }^{* * *}$ & ${ }^{* * *}$ \\
\hline Sedimentation & ${ }^{* *}$ & ${ }^{* *}$ & ${ }^{* * *}$ & \\
\hline
\end{tabular}

Note: stars indicating level of problem intensity on each areas

\section{Erosion (abrasion) in Peusangan River}

Riverbank collapse in the downstream part of the Krueng Peusangan watershed is shifting the riverbed. Settlement, farming, as well as fishpond located on riparian area were subsided as an impact of abrasion. In Mon Kelayu village (Gandapura) the abrasion reached until 30 meters from riverbank (http://www.rapi0107.org/cetak.php?id=171) and the group discussion in Bireun confirmed this problem. In the Krueng Beukah village, Lhung Kuli and Cebrek village, Peusangan Selatan sub-district, 40 ha of farmland disappeared into the water (http://www.serambinews.com/news/view/21165/abrasi-krueng-peusangan-meluas).

High intensity of flood caused erosion and abrasion. Local communities perceived that flood had become more frequent since the forest in the upstream was logged or converted into others land cover type (Figure 12). The intensity of the abrasion is more frequent with decreasing and poor vegetation canopy cover and fragile soil structure on the riparian areas. The role of trees in the riparian zone is very important to stabilize riverbanks.

\section{Riparian vegetation on Peusangan Watershed}

Waru or Siron (Hibiscus tiliaceus L.), bamboo and jaloh (Salix tetrasperma Roxb) are the main species that have high environmental value in reducing erosion impact on river banks. Full-grown Jaloh and Siron or Waru have fibrous roots that have good soil binding capability. The natural habitat of those two species is river bank areas. However, during high intensity of flood or flow of river, in the area with young waru or siron the role of 'bronjong' is also very important to protect the riverbank collapse. 


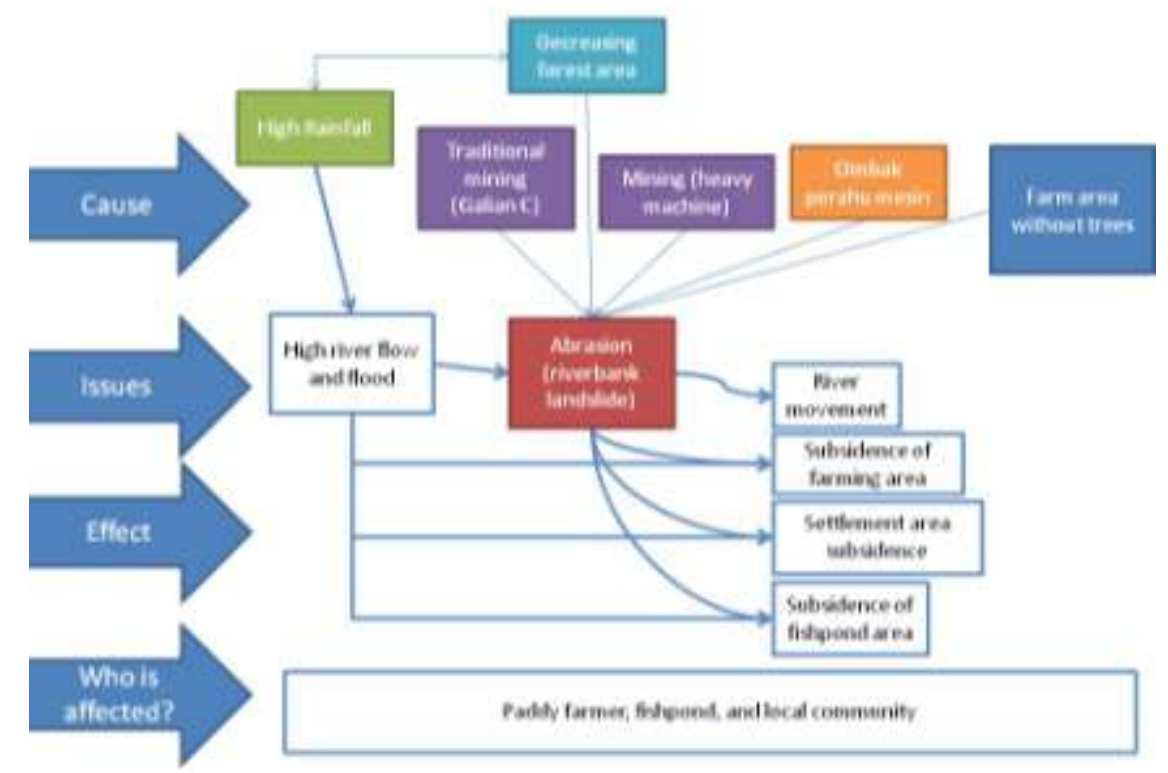

Figure 12. Local community perspectives on the cause and impact of abrasion

\section{River flow decreasing along the Peusangan river and siltation in Lake Laut Tawar}

The forest in the upstream area that degraded into logged-over forest or was converted into other land cover types not only have an effect on erosion and abrasion, but also decreasing the quantity of river flow during the dry season and siltation into Lake Laut Tawar. Local fisheries both using floating or pen culture, and fishing communities are significantly affected (Figure 13).

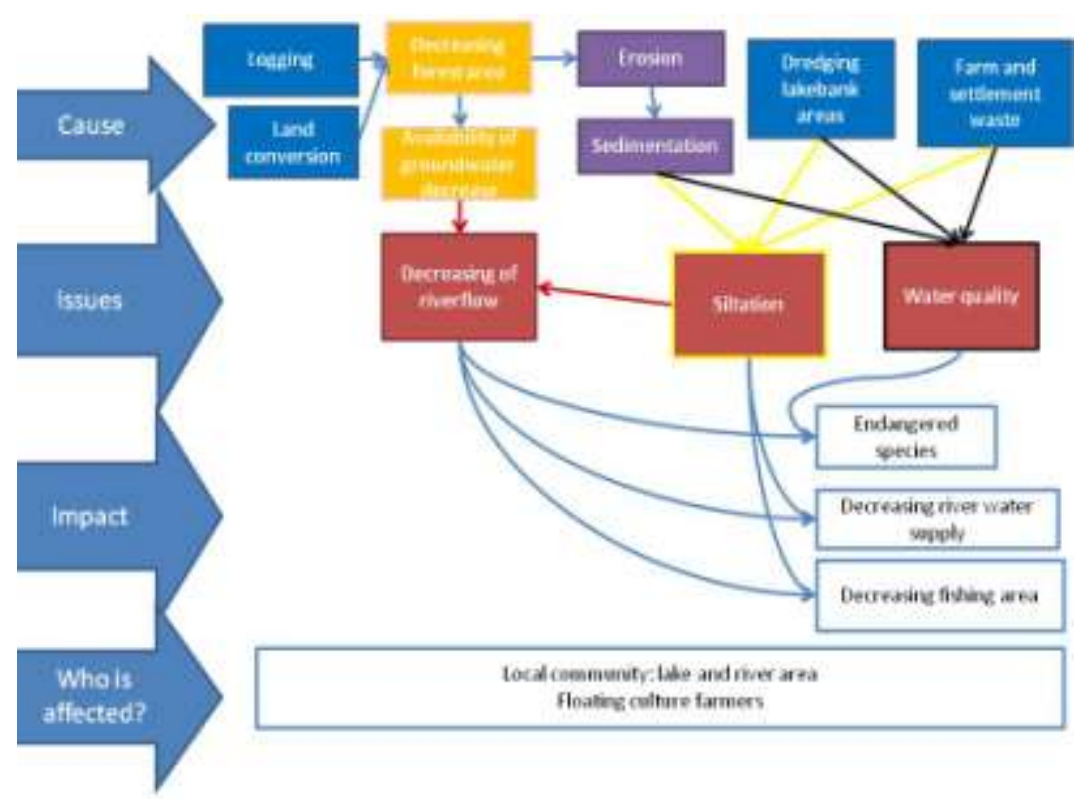

Figure 13. Local community perspectives on the cause and impact of decreasing of river flow, sedimentation and water quality 


\subsubsection{Knowledge of related stakeholder on hydrological problems}

In this study, public perceptions were gathered mainly from district and provincial government staffs. Their perception of hydrological issues was analyzed based on some interviews and discussion with relevant stakeholder, literature review and documentation analysis. Some interviews with Agricultural and Forestry agency were undertaken in upstream area (Aceh Tengah), and Forest agency in provincial level. Proceeding of Workshop on collaborative and sustainability management of the Krueng Peusangan watershed in Takengon on March 25, 2008 were also used as a basis of stakeholder perception analysis.

Interview with stakeholders in down to midstream clearly indicated that the Krueng Peusangan watershed played very important role on economic, farming (irrigation), clean water provider, and also provided ecological function for community living in surrounding Peusangan River. Most of recognizing hydrological problems was similar to local perception, abrasion, erosion, flooding, and sedimentation.

Forest clearing and small or large scales mining activities were the main factors causing the problems (Figure 14). Other important issues that had mentioned by forestry agency were wild forage systems of cow that were common in Pidie, Bireun, Aceh Utara, Aceh Tengah (Takengon), and buffalo that were common in Pidie, Aceh Tengah, Aceh Utara, and Bener Meriah (Bandar). Wild foraging caused the loose of soil structures and easily eroded.

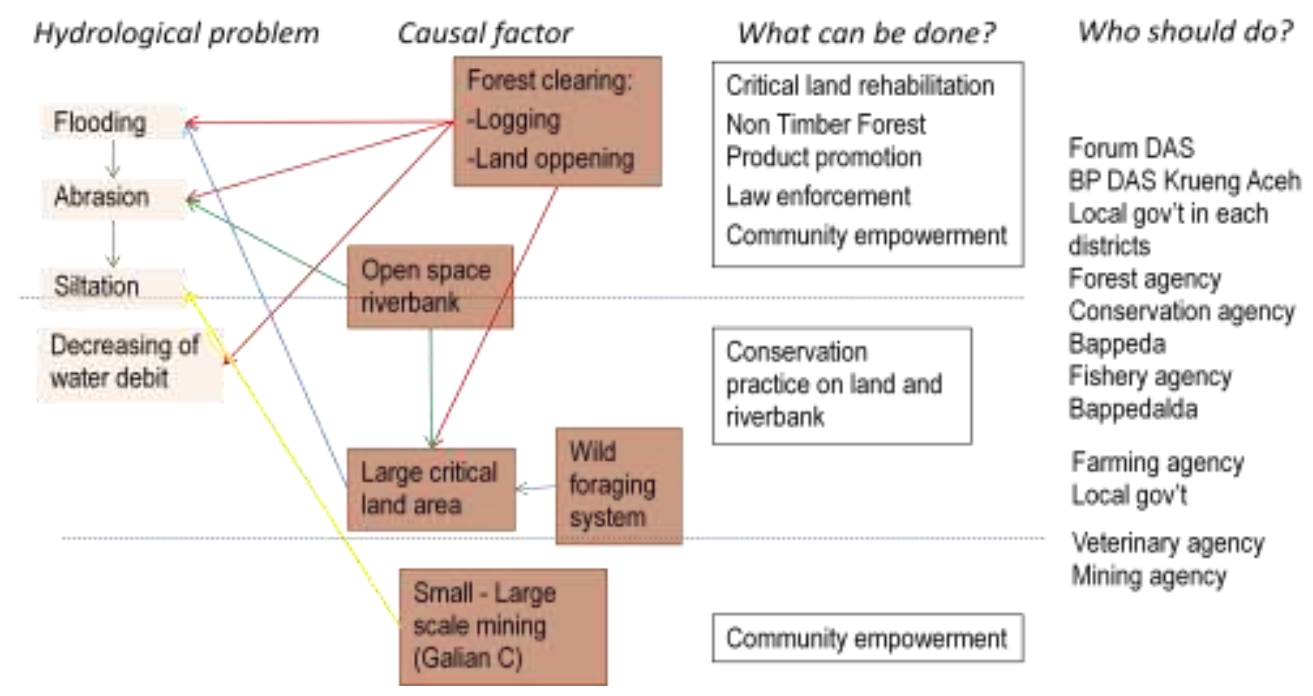

Figure 14. Stakeholder perspectives on main hydrological problems and the causal factors on downmidstream of the Krueng Peusangan watershed

In Lake Laut Tawar, sedimentation became the main issues as perceived by most of stakeholder (Figure 15) as well as local community. Sedimentation is the repository for materials carried into the lake by erosion, and is subsequently transported by the action of water. The quantity of sediment in the Lake Laut Tawar has yet to be measured, but the phenomenon of sedimentation in the Lake Laut Tawar can be seen from the changes of lake surface, turbidity, suspend solid, mud content, and depth of lake. 
Low qualities of Lake Laut Tawar water also became the main issues largely debate across stakeholder who concern on the Lake Laut Tawar. Some factors identified as the cause of water quality decreasing are household, hotels and resorts waste without proper treatment; chemical and fertilizer used by agricultural activities; aquaculture with high protein content (commercial pellets) and poison as other pollutant.

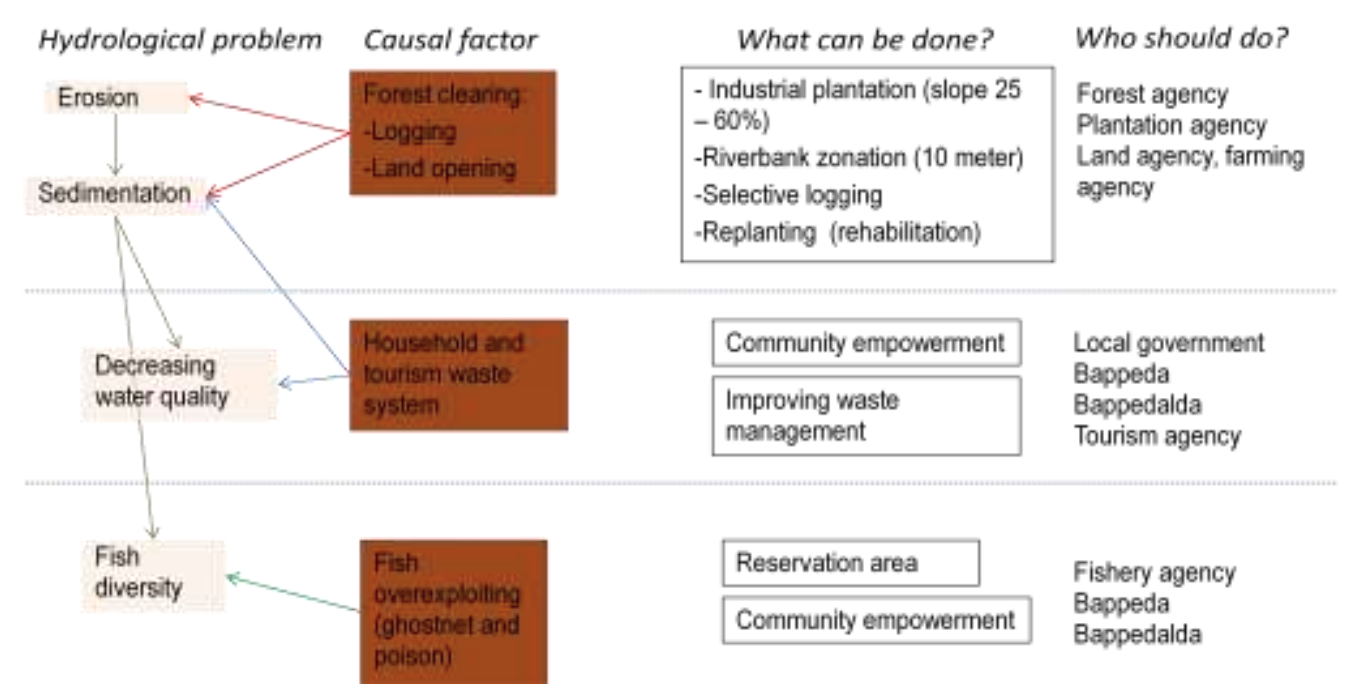

Figure 15. Stakeholder perspectives on the hydrological problems and cause of Lake Laut Tawar and upstream of the Krueng Peusangan watershed

\subsection{Analysis of Climate and Hydrology Data}

\subsubsection{Analysis of Rainfall Data}

Daily rainfall data that cover the Krueng Peusangan watershed was generated based on monthly average data (www.worldclim.com) and daily rainfall data of station Meteorology Class III Lhokseumawe, Malikussaleh Airport using rainfall simulator model resulted very good predicted data (Table 20).

\subsubsection{Analysis of Rainfall - River Flow}

Three forms of river flow analysis by calculating total evapotranspiration, plotting cumulative $\mathrm{Q}$ versus cumulative $P$ during the year, plotting flow persistence $Q_{i+1}$ versus $Q_{i}$ gives consistence result (Table 18, Figure 16 and 17). A series of fine-tuning data result a good quality of rainfall - river flow data except for year 1996/1997. Total evapotranspiration and coefficient correlation of year 1996/1997 was below $500 \mathrm{~mm}$ and 0.5 , respectively (Table 18). The graph of cumulative rainfall river flow curve that indicate extreme slope changing in the plot and the graph of flow persistence $\mathrm{Q}_{\mathrm{i}+\mathrm{I}}$ versus $\mathrm{Q}_{\mathrm{i}}$ confirmed the fact (Figure 16 and 17). 
Table 18. Rainfall - River flow data analysis, $\sum \mathrm{P}-\sum \mathrm{Q}$

\begin{tabular}{rccc}
\hline Tahun & Rainfall $\mathbf{( P )}, \mathbf{m m}$ & Discharge $(\mathbf{Q}), \mathbf{m m}$ & $\sum \mathbf{P}-\Sigma \mathbf{Q}$ \\
\hline $1991 / 1992$ & 2289 & 1358 & 931 \\
\hline $1992 / 1993$ & 1458 & 720 & 737 \\
\hline $1993 / 1994$ & 1459 & 689 & 770 \\
\hline $1994 / 1995$ & 2251 & 1343 & 908 \\
\hline $1995 / 1996$ & 1568 & 783 & 784 \\
\hline $1996 / 1997$ & 1121 & 642 & 478 \\
\hline
\end{tabular}

Note: Rainfall data is predicted rainfall
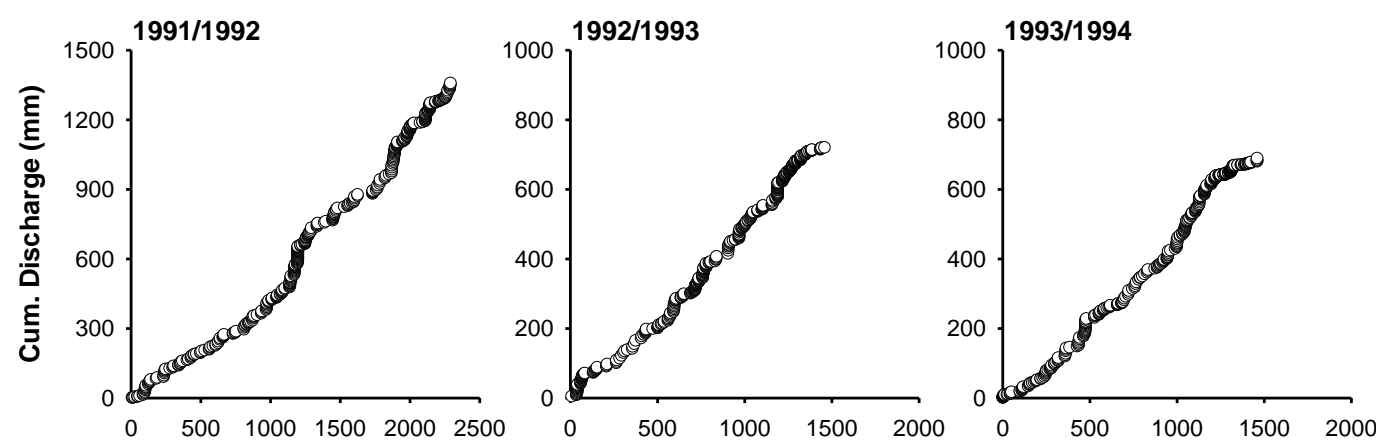

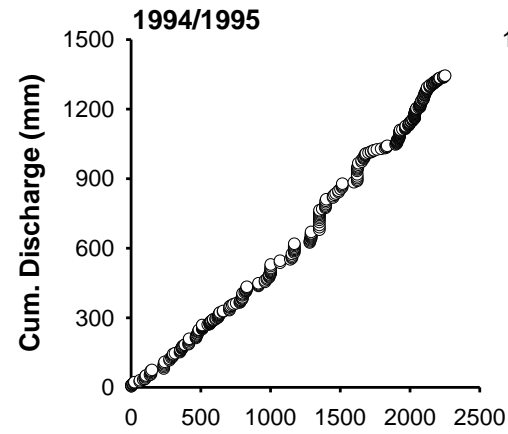

Cum. Rainfall (mm)

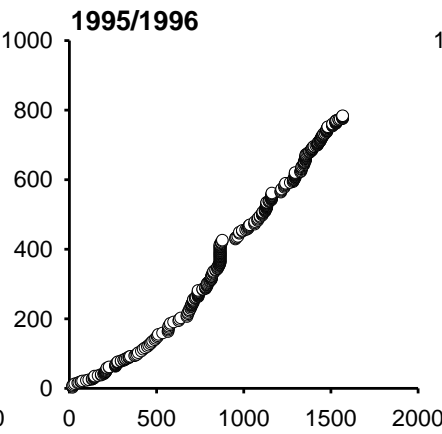

Cum. Rainfall (mm)

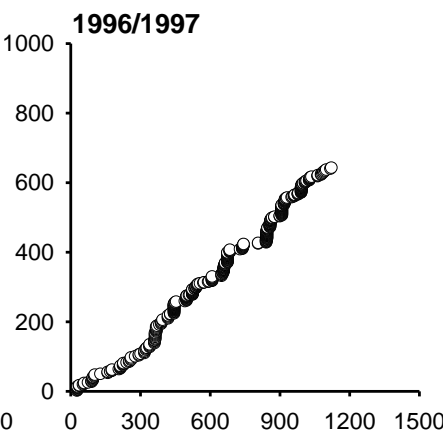

Cum. Rainfall (mm)

Figure 16. Double mass cumulative rainfall - river flow curve. 
Table 19. Generated monthly rainfall data (1991 - 2009) using rainfall simulator

\begin{tabular}{|c|c|c|c|c|c|c|c|c|c|c|c|c|c|c|c|c|}
\hline \multirow{2}{*}{ Year } & \multicolumn{12}{|c|}{ Month } & \multirow{2}{*}{\multicolumn{2}{|c|}{ Coefficient Correlation }} & \multirow{2}{*}{\multicolumn{2}{|c|}{ Bias (\%) }} \\
\hline & 1 & 2 & 3 & 4 & 5 & 6 & 7 & 8 & 9 & 10 & 11 & 12 & & & & \\
\hline 1991 & 164.0 & 0.0 & 144.9 & 176.4 & 306.0 & 41.2 & 91.1 & 62.6 & 116.6 & 247.4 & 375.6 & 312.3 & 0.84 & Satisfactory & 10.26 & Good \\
\hline 1992 & 202.8 & 58.5 & 50.5 & 213.1 & 368.1 & 119.6 & 79.6 & 115.4 & 146.3 & 81.7 & 351.2 & 171.0 & 0.41 & Unsatisfactory & 5.91 & Very Good \\
\hline 1993 & 133.0 & 41.7 & 188.6 & 107.4 & 114.3 & 54.6 & 48.0 & 29.2 & 137.0 & 157.8 & 199.3 & 169.1 & 0.88 & Satisfactory & 25.34 & Unsatisfactory \\
\hline 1994 & 168.6 & 230.1 & 124.7 & 78.3 & 90.7 & 62.4 & 29.4 & 11.5 & 137.1 & 277.5 & 201.6 & 127.7 & 0.62 & Satisfactory & 16.70 & Satisfactory \\
\hline 1995 & 217.1 & 244.5 & 282.3 & 272.1 & 285.0 & 63.0 & 75.6 & 77.4 & 127.4 & 215.7 & 208.3 & 271.6 & 0.69 & Satisfactory & 26.59 & Unsatisfactory \\
\hline 1996 & 86.5 & 80.2 & 2.3 & 242.1 & 54.3 & 165.2 & 70.1 & 81.1 & 90.3 & 207.3 & 152.8 & 84.9 & 0.21 & Unsatisfactory & 28.75 & Unsatisfactory \\
\hline 1997 & 53.6 & 58.2 & 106.4 & 75.4 & 105.6 & 64.1 & 14.1 & 71.7 & 126.8 & 265.1 & 326.7 & 161.8 & 0.77 & Satisfactory & 22.67 & Satisfactory \\
\hline 1998 & 157.9 & 266.9 & 170.2 & 206.7 & 105.5 & 149.7 & 89.5 & 60.4 & 112.3 & 331.5 & 276.7 & 290.4 & 0.72 & Satisfactory & 19.98 & Satisfactory \\
\hline 1999 & 199.6 & 164.6 & 125.6 & 110.7 & 177.5 & 58.7 & 54.0 & 59.8 & 189.2 & 295.6 & 173.6 & 236.4 & 0.82 & Satisfactory & 0.17 & Very Good \\
\hline 2000 & 398.4 & 69.6 & 169.8 & 180.8 & 93.9 & 67.4 & 119.1 & 79.0 & 115.2 & 351.1 & 228.9 & 324.1 & 0.77 & Satisfactory & 18.88 & Satisfactory \\
\hline WorldClim & 174.8 & 117.4 & 164.0 & 166.1 & 154.6 & 79.3 & 78.9 & 92.7 & 147.1 & 213.1 & 225.1 & 235.1 & & & & \\
\hline 2001 & 239.6 & 169.1 & 177.3 & 169.2 & 193.5 & 69.1 & 22.3 & 99.5 & 86.6 & 351.7 & 216.0 & 241.3 & 0.90 & Satisfactory & 1.00 & Very Good \\
\hline 2002 & 332.5 & 85.0 & 156.8 & 21.2 & 42.5 & 41.4 & 77.5 & 20.3 & 48.7 & 429.3 & 313.6 & 266.7 & 0.78 & Satisfactory & 10.72 & Good \\
\hline 2003 & 296.5 & 116.1 & 181.5 & 98.7 & 114.9 & 92.3 & 80.2 & 63.1 & 205.0 & 288.9 & 225.1 & 274.5 & 0.85 & Satisfactory & 0.92 & Very Good \\
\hline 2004 & 150.6 & 128.6 & 126.4 & 142.3 & 184.6 & 105.5 & 54.6 & 84.6 & 109.3 & 155.0 & 228.0 & 253.9 & 0.80 & Satisfactory & 16.17 & Satisfactory \\
\hline 2005 & 215.2 & 166.8 & 264.1 & 255.8 & 73.6 & 67.2 & 58.5 & 131.0 & 173.1 & 192.2 & 198.7 & 265.6 & 0.71 & Satisfactory & 0.29 & Very Good \\
\hline 2006 & 242.7 & 134.1 & 217.3 & 147.5 & 140.5 & 126.2 & 86.6 & 84.0 & 88.1 & 173.8 & 181.1 & 219.5 & 0.76 & Satisfactory & 10.44 & Good \\
\hline 2007 & 190.0 & 142.4 & 95.4 & 134.0 & 85.0 & 132.0 & 58.6 & 127.4 & 117.3 & 363.2 & 244.1 & 347.3 & 0.76 & Satisfactory & 0.93 & Very Good \\
\hline 2008 & 128.7 & 188.7 & 273.4 & 226.3 & 179.4 & 91.1 & 67.1 & 205.0 & 208.5 & 366.5 & 229.9 & 202.1 & 0.70 & Satisfactory & 15.11 & Satisfactory \\
\hline 2009 & 234.5 & 120.4 & 355.4 & 76.0 & 201.6 & 32.7 & 23.0 & 56.5 & 39.4 & 354.2 & 141.9 & 182.1 & 0.75 & Satisfactory & 11.59 & Good \\
\hline WorldClim & 201.3 & 131.8 & 193.6 & 176.7 & 180.7 & 101.9 & 92.0 & 114.0 & 163.1 & 247.4 & 215.1 & 238.0 & & & & \\
\hline
\end{tabular}



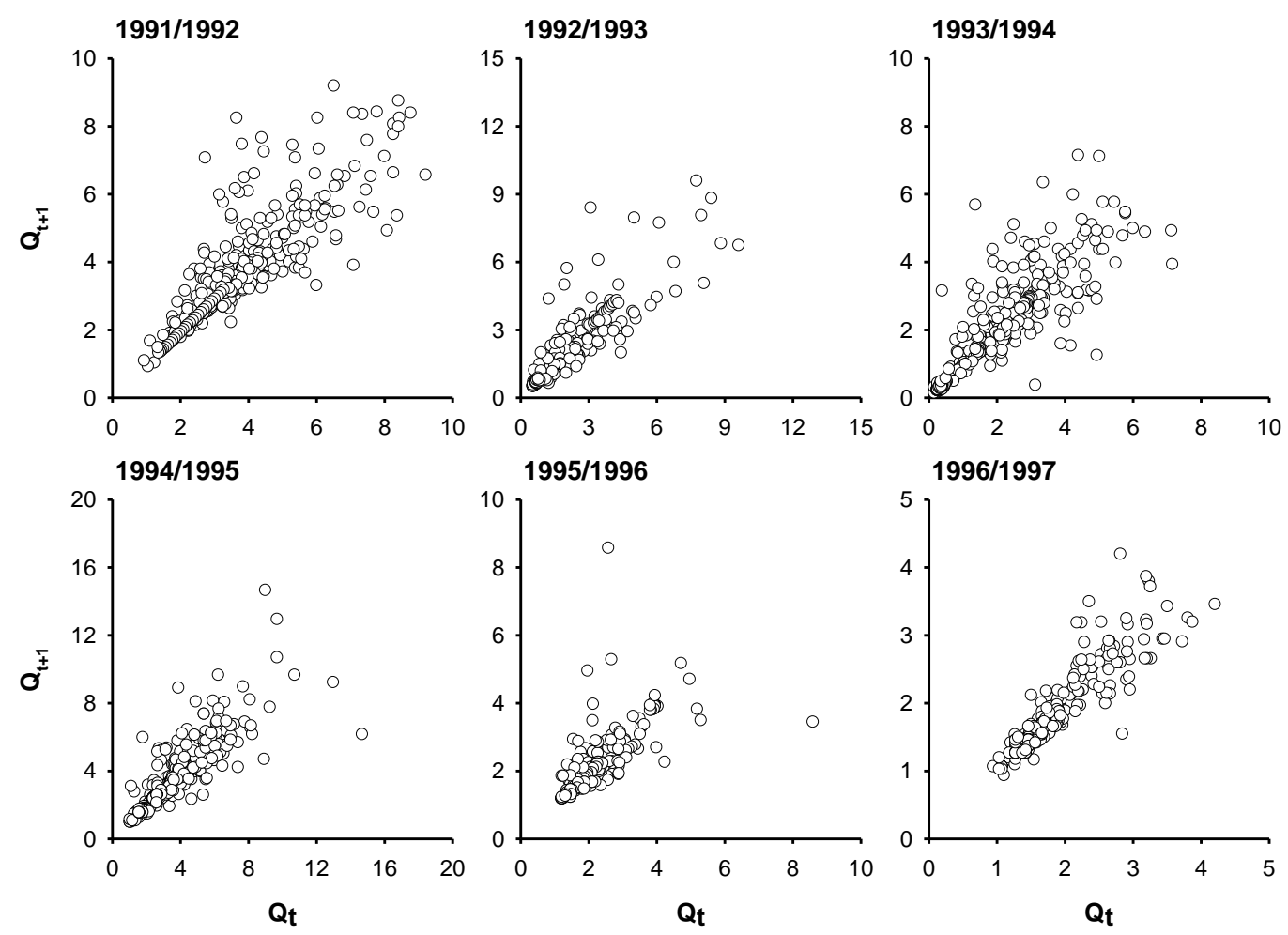

Figure 17. Flow persistence $\mathrm{Q}_{\mathrm{i}+\mathrm{I}}$ versus $\mathrm{Q}_{\mathrm{i}}$ plots.

\subsection{Spatial Analysis: Land Cover/Land Cover Change and Watershed Characteristic Analysis}

\subsubsection{Terrain processing for watershed delineation}

Terrain processing result showed that the Krueng Peusangan watershed consist of 11 sub catchment. Based on elevation, the sub-catchments can be classified into four upper catchments (UC), two middle catchments (MC) and 5 lower catchments (LC) (Figure 18). More than 69\% of the total area of the Krueng Peusangan watershed is located in the higher elevation. Details on size and proportion of each sub-catchment are showed in Table 20.

Table 20. Sub-catchment area of the Krueng Peusangan watershed

\begin{tabular}{crc}
\hline Sub-catchment & Area (ha) & Proportion \\
\hline LC1 & $13,570.0$ & $6 \%$ \\
\hline LC2 & $30,551.0$ & $13 \%$ \\
\hline LC3 & $18,561.2$ & $8 \%$ \\
\hline LC4 & $6,723.1$ & $3 \%$ \\
\hline MC1 & $36,217.1$ & $16 \%$ \\
\hline MC2 & $32,473.5$ & $14 \%$ \\
\hline UC1a & $19,799.5$ & $9 \%$ \\
\hline UC1b & $19,239.4$ & $8 \%$ \\
\hline UC2 & $23,935.1$ & $11 \%$ \\
\hline UC3 & $13,742.9$ & $6 \%$ \\
\hline UC4 & $12,035.7$ & $5 \%$ \\
\hline
\end{tabular}




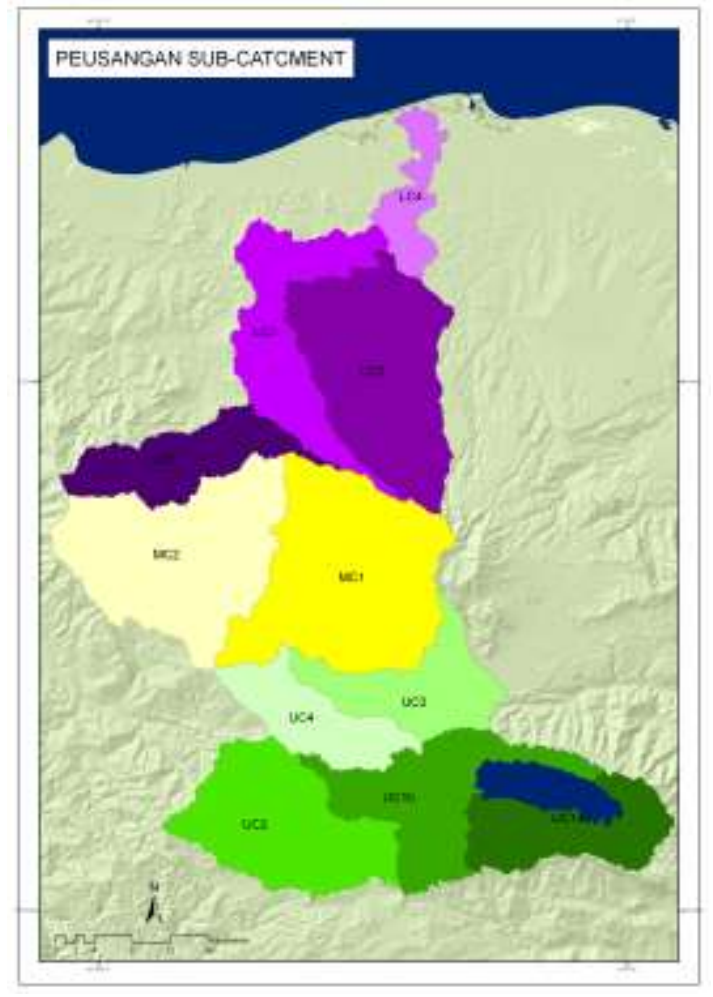

Figure 18. Sub-catchment of the Krueng

Peusangan watershed

\subsubsection{Time series land cover maps of the Krueng Peusangan watershed}

One of the crucial phases in ALUCT is defining land cover classification scheme for satellite image interpretation. We defined our land cover classes based on field observation conducted in January 2010. We found that the landscape of the Krueng Peusangan is dominated by three types of land cover: (1) Forest classes, (2) Agroforest classes and (3) Cropland. Forest classes can be divided into undisturbed and logged over forest. Agroforest class consists of coffee agroforest, mixed garden and coconut agroforest.

During field observations, we collected a number of GPS points for each land cover classes. The data will serve (1) as sample for image interpretation process and (2) as references for accuracy assessment. Figure 19 shows the collection GPS points.

We conducted accuracy assessment for 2009 land cover map using 260 GPS points. The overall accuracy is $80.3 \%$. Some misclassification occurred between classes of mixed garden, coffee agroforest and coconut agroforest, which is mostly due to the similarity of canopy covers. Accuracy for land cover classes is presented in Table 21. 


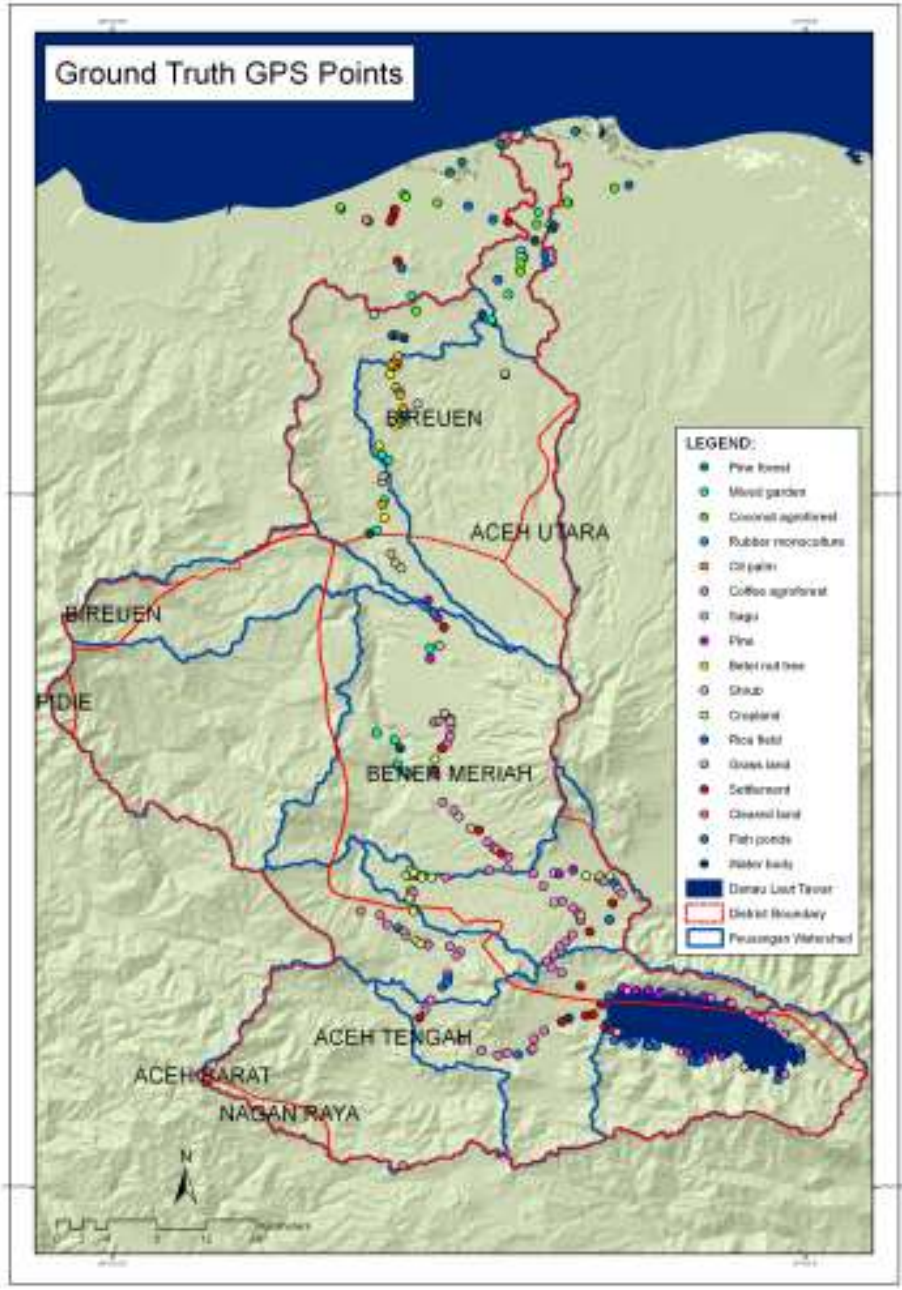

Figure 19. GPS points for accuracy assessment

Table 21. Accuracy assessment result

\begin{tabular}{lll}
\hline \multicolumn{1}{c}{ ID } & \multicolumn{1}{c}{ Classs name } & User's accuracy \\
\hline $\mathbf{1}$ & Betel nut tree & $90.0 \%$ \\
\hline $\mathbf{2}$ & Cleared land & $90.0 \%$ \\
\hline $\mathbf{3}$ & Coconut agroforest & $62.5 \%$ \\
\hline $\mathbf{4}$ & Coffee agroforest & $78.5 \%$ \\
\hline $\mathbf{5}$ & Cropland & $82.4 \%$ \\
\hline $\mathbf{6}$ & Fish ponds & $89.0 \%$ \\
\hline $\mathbf{7}$ & Grass land & $71.4 \%$ \\
\hline $\mathbf{8}$ & Mixed garden & $59.1 \%$ \\
\hline $\mathbf{9}$ & Oil palm & $69.2 \%$ \\
\hline $\mathbf{1 0}$ & Logged over pine & $84.6 \%$ \\
\hline $\mathbf{1 1}$ & Pine forest & $87.0 \%$ \\
\hline $\mathbf{1 2}$ & Rice field & $95.8 \%$ \\
\hline $\mathbf{1 3}$ & Rubber monoculture & $91.0 \%$ \\
\hline $\mathbf{1 5}$ & Settlement & $95.2 \%$ \\
\hline $\mathbf{1 6}$ & Shrub & $75.0 \%$ \\
\hline
\end{tabular}


The time series land cover maps in Figure 20 clearly show a different land use composition in the upper, middle and lower catchment of the watershed. In the upper catchment, patches of mosaics of coffee agroforest and pine forests are identified in the surrounding area of Lake Air Tawar. Largest patches of forest and coffee agroforest are located in the middle part of the watershed. In the lower catchment, the land use composition consist of mixed garden, coconut, cropland and some patches of oil palm plantation near the coastal land.
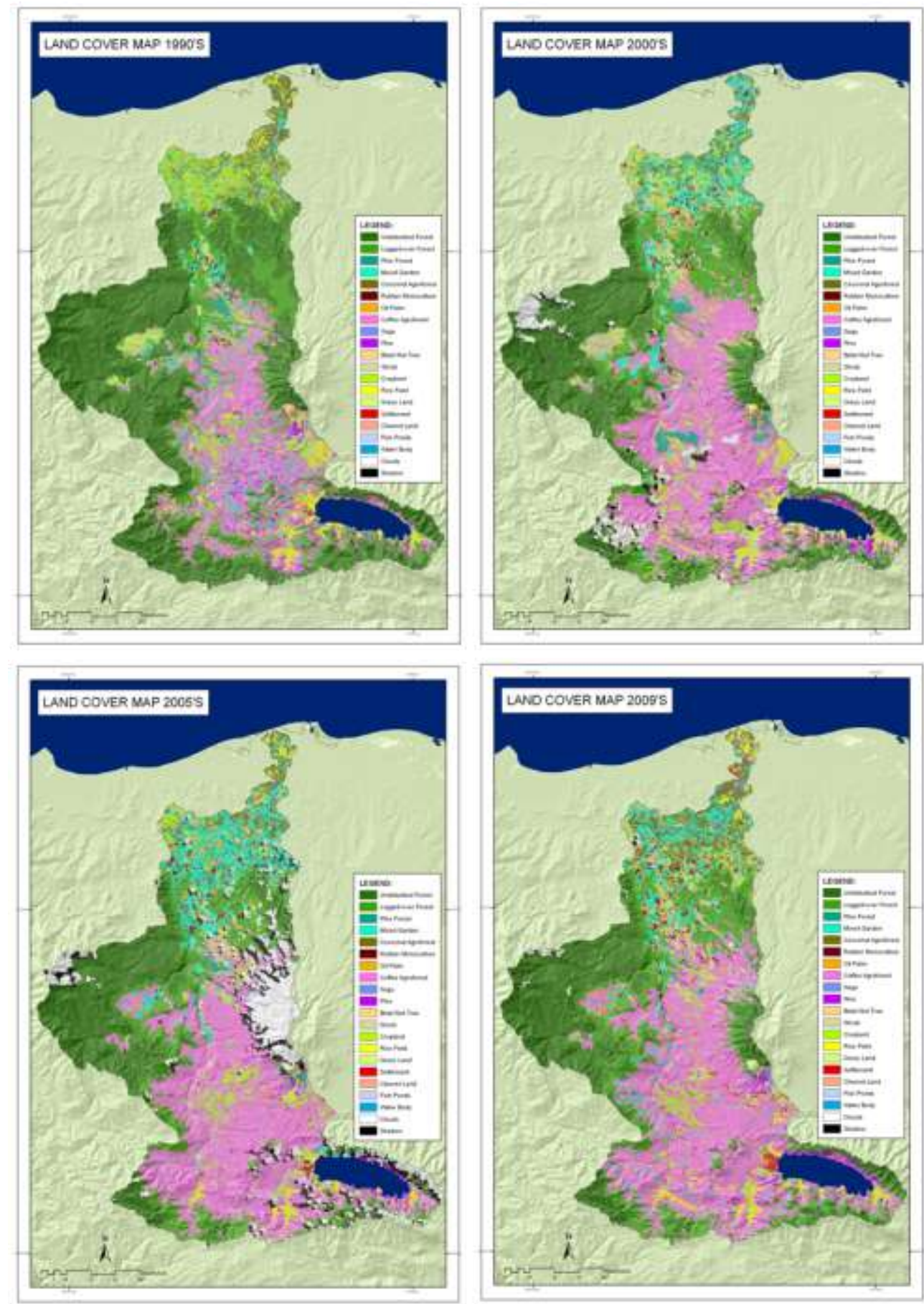

Figure 20. Time series land cover maps of the Krueng Peusangan watershed 


\subsubsection{Land cover change and trajectories of Krueng Peusangan watershed}

The overall of the Krueng Peusangan land cover change in 1990-2009 is presented in Table 22. The data shows four type of trend: (1) decreasing area of forest cover (2) increasing area of coffee agroforest, (3) increasing area of oil palm in the lower catchment of the area, and (4) decrease of pine forest area. Undisturbed forest is slightly decreased from $26 \%$ of total Krueng Peusangan watershed (67,597 ha) in 1990 to 13\% (34,403 ha) in 2009. Logged over forest increase from 9\% $(23,951 \mathrm{ha})$ in 1990 to $11 \%(28,109$. ha) in 2009 . This can be an indication of natural forest degradation caused by timber extraction activity.

On the other hand, coffee agroforest area increase from 14\% (36,462 ha) in 1990 to 23\% (60,204 ha) in 2009. Most of the coffee agroforest area are located in the upper and middle catchment of the Krueng Peusangan watershed. Oil palm plantations were identified in the land cover map of 2000. The area are relatively small but rapidly increase from $1 \%$ (2,612 ha) in 2005 to $2 \%$ (6,157 ha) in 2009. Oil palm area are located in the lower part of the Krueng Peusangan watershed. Overall figure of land cover changes in Krueng Peusangan can be seen in Figure 21.

Table 22. Area of change for each land cover type in the Krueng Peusangan watershed 1990-2009

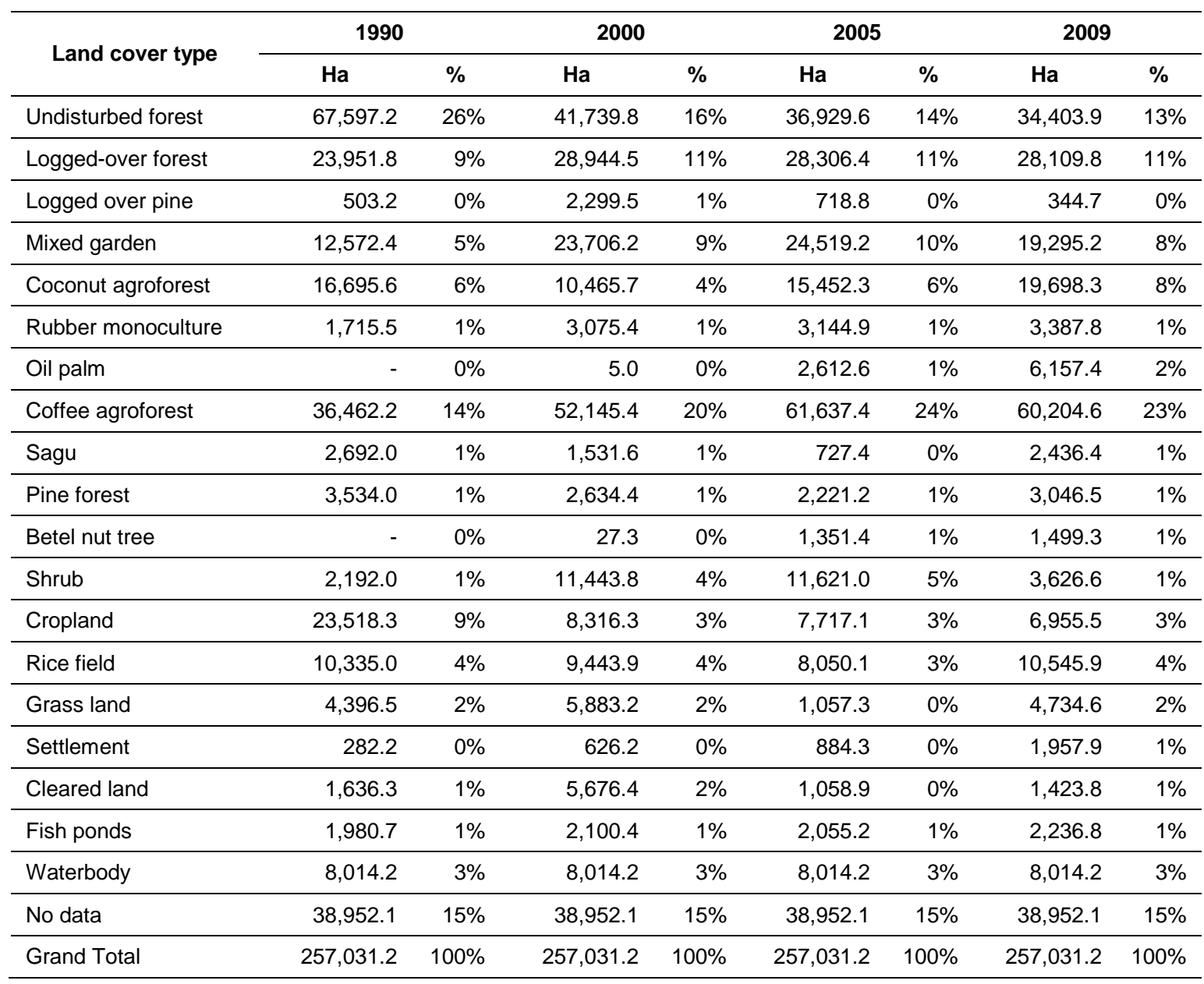




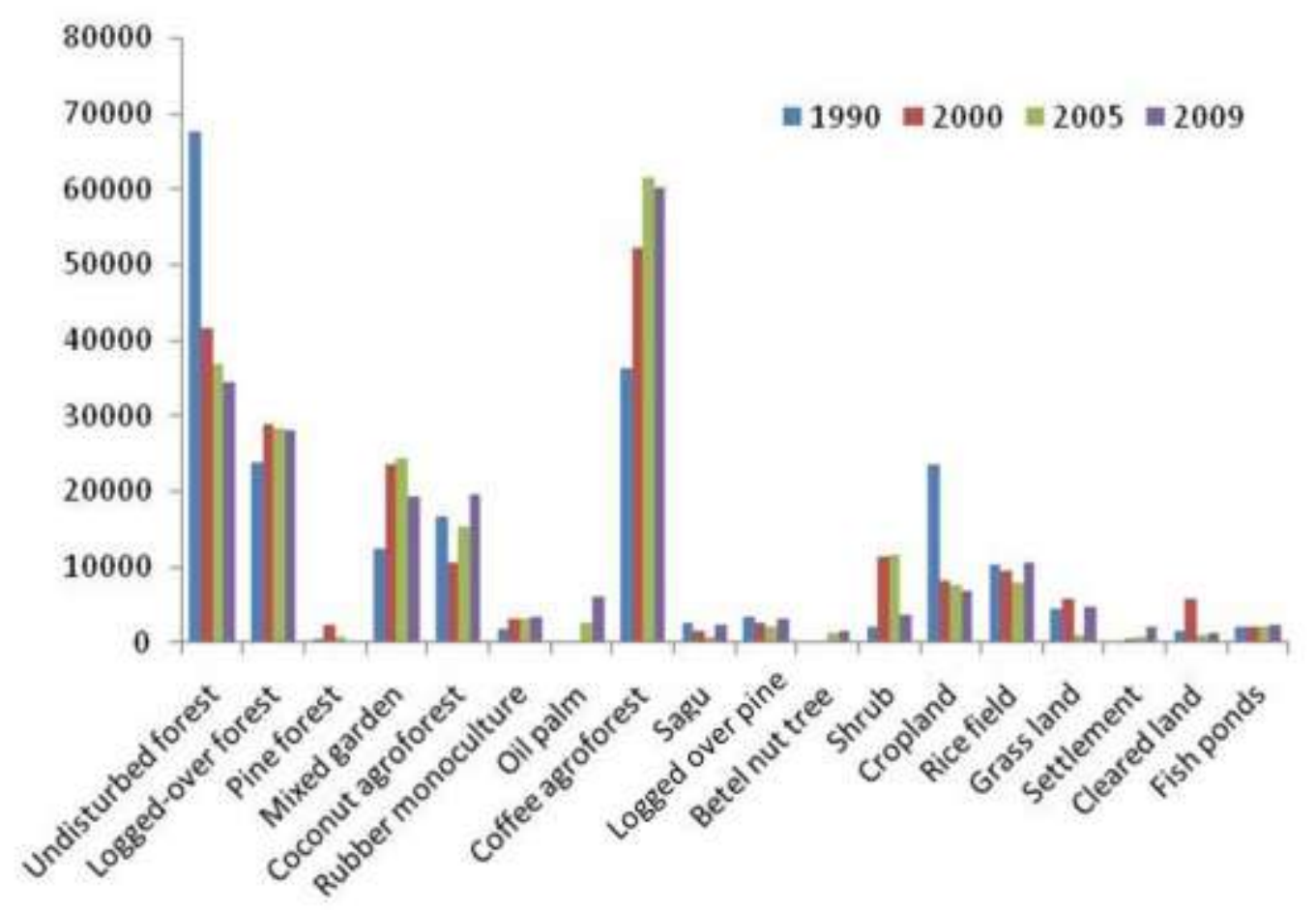

Figure 21. Overall land cover change of the Krueng Peusangan watershed

Deforestation is one of dominant land cover change in the Krueng Peusangan watershed. The highest rate of deforestation occurred in 1990 - 2000. Figure 22 showed an analysis of deforestation in the sub-catchment area of the Krueng Peusangan watershed. The largest proportion of deforestation in 1990 - 2000 occurred in the upper and lower catchment. Deforestation is clearly slowed down in $2000-2009$.

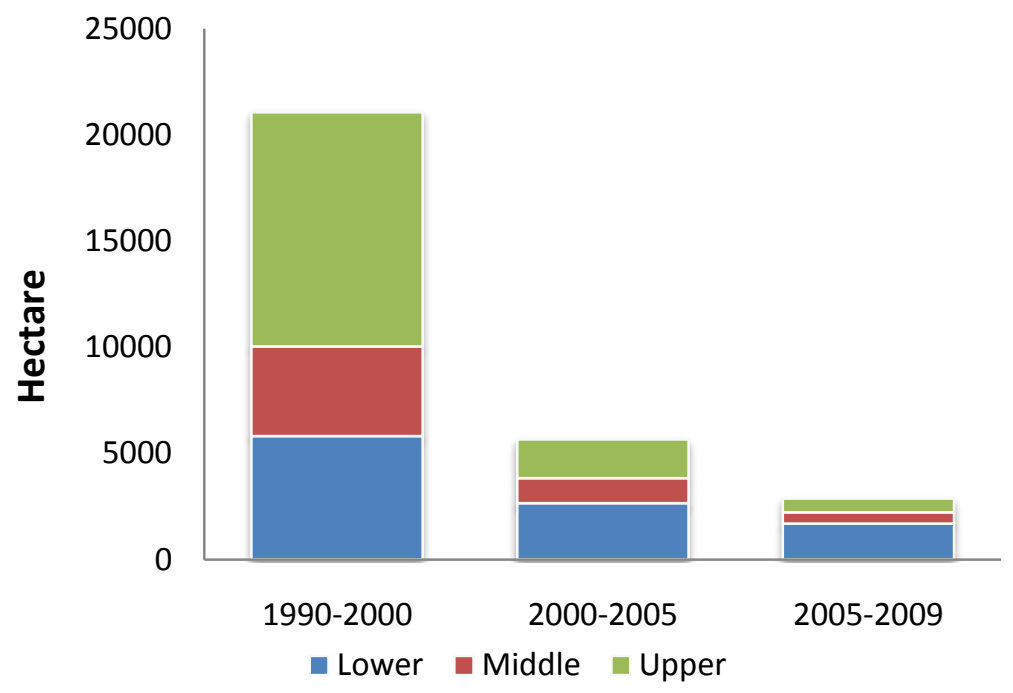

Figure 22. Deforestation in the Krueng Peusangan watershed 
Based on land cover change data, we conducted a trajectories analysis of land to produce a simple summary of dominant land cover changes in the Krueng Peusangan watershed within the study period. Trajectories map is shown in Figure 23 and summary of trajectories analysis is presented in Figure 24. It is shown that the dominant trajectories in the Krueng Peusangan watershed are (1) natural forest conversion to agroforest and (2) natural forest degradation. Natural forest degradation is mostly located in the upper catchment, while natural forest conversion to agroforest is located in the middle catchment (Figure 24).

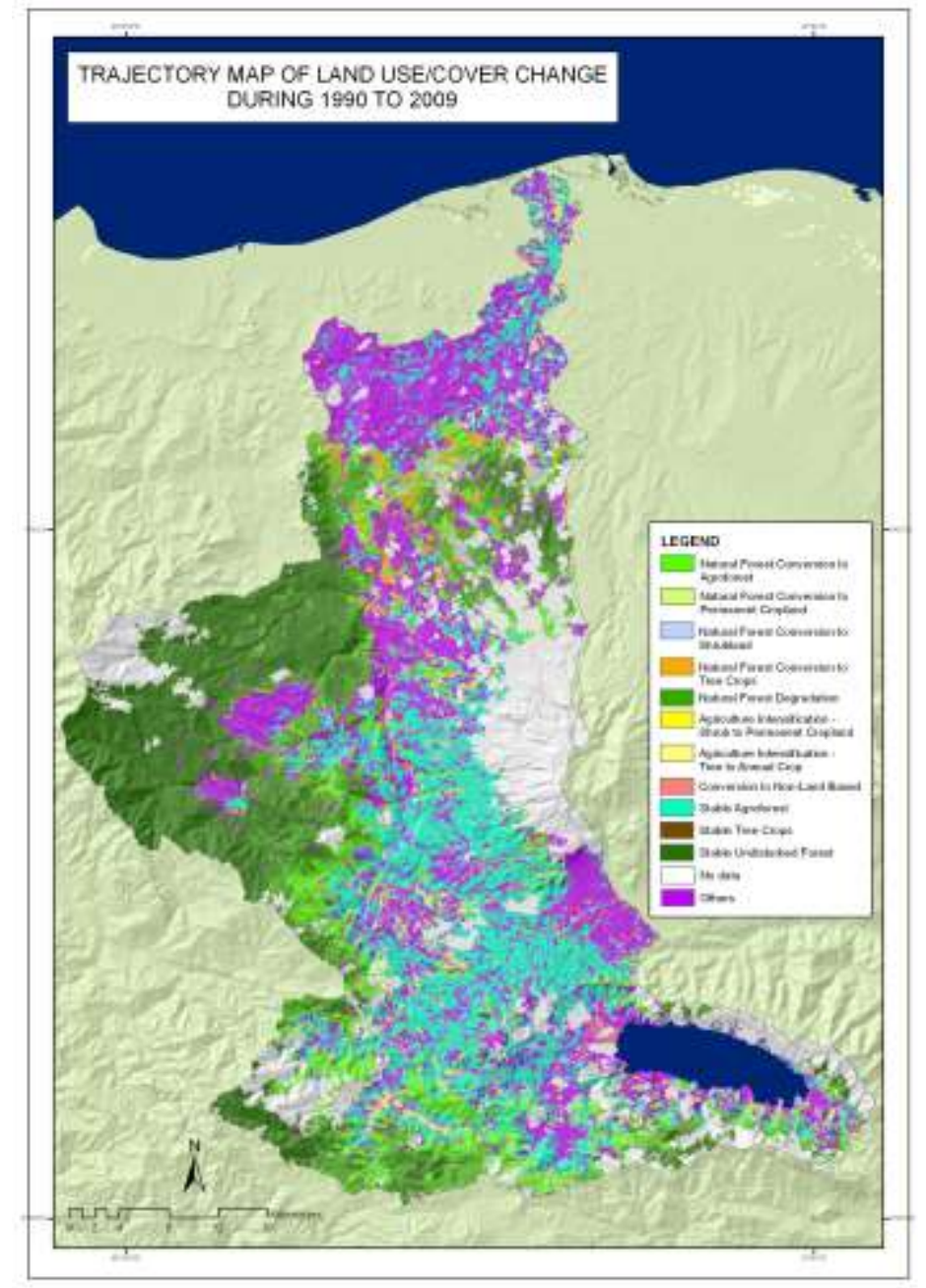

Figure 23. Land use trajectories map of the Krueng Peusangan watershed 


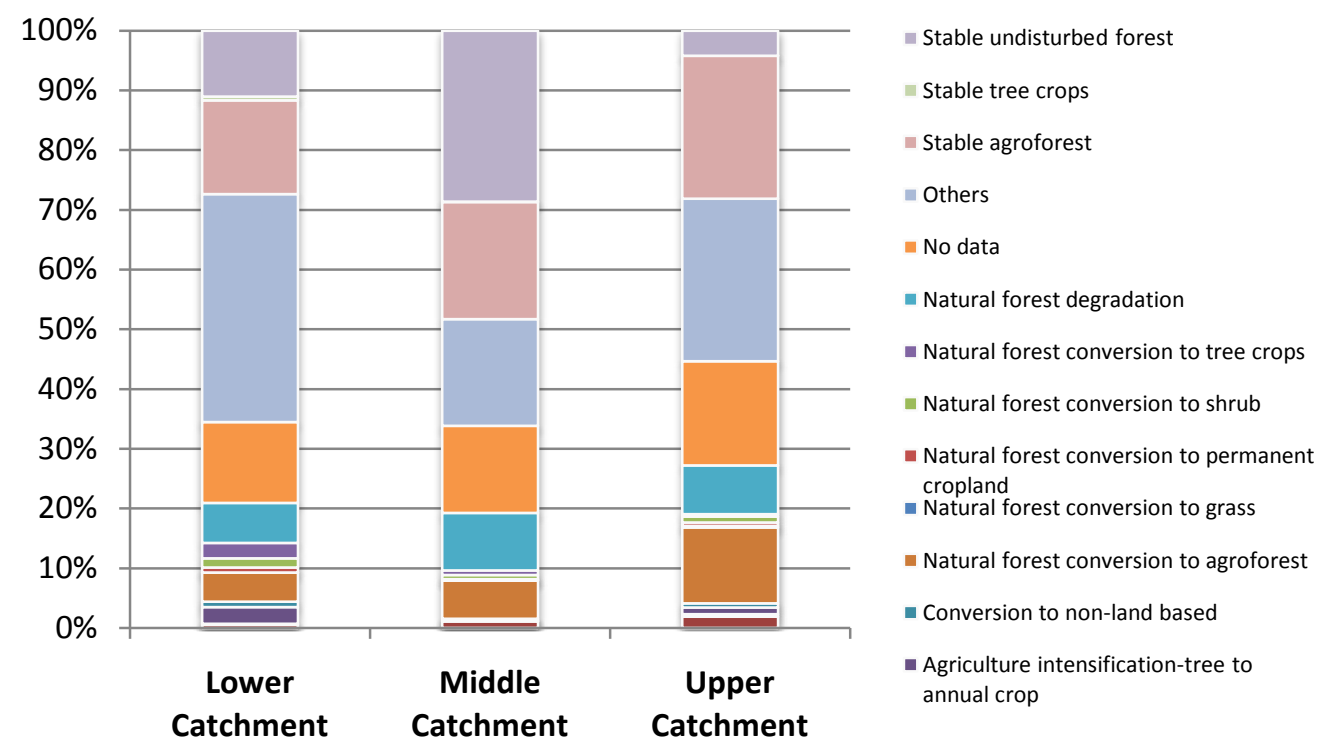

Figure 24. Land use trajectories for each sub-catchment of the Krueng Peusangan watershed

\subsection{Analyses on the Consequences of Current and Future Land Cover Change on Water Balance Including River Flow}

\subsubsection{Model calibration and validation}

\section{Model performance on river discharge}

Model calibration and validation process use the six years available discharge data. The cumulative values of daily discharge, in general showed a good agreement between measurement and simulation (Figure 25). A more detail pattern is comparison of plot flow persistence $\mathrm{Q}_{\mathrm{i}+\mathrm{I}}$ versus $\mathrm{Q}_{i}$ and a temporal trends (Figure 26 and 27). We found a weak relationship for the lowest or the highest between measured and simulated discharge on a daily basis. However, the statistical test for Figure $26-28$ resulted a very good or good comparison (the biased less than 20\%) except for year 1993/1994 (Table 23), hence, this difference is within acceptable limits. 

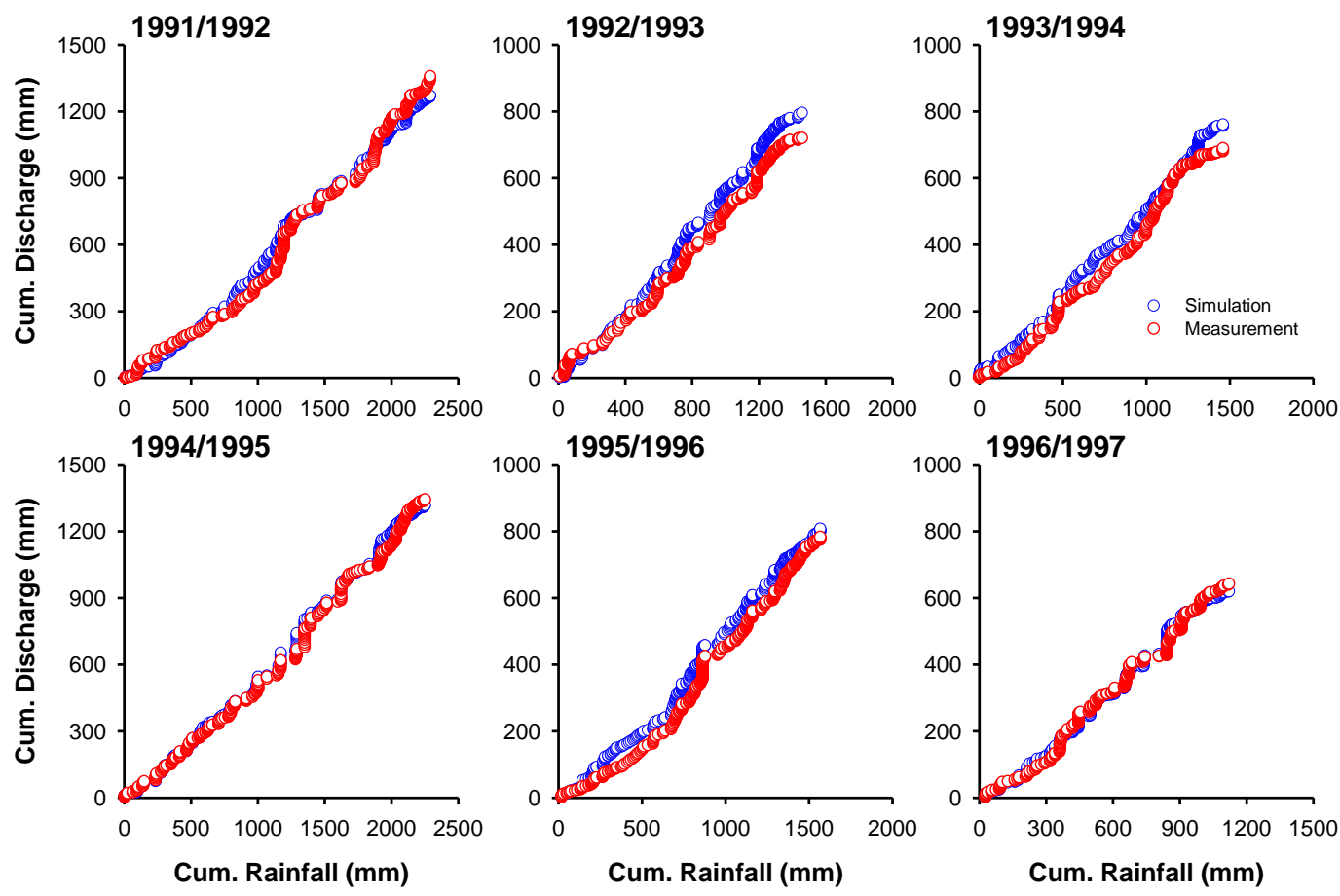

Figure 25. Plot of cumulative rainfall vs cumulative discharge of simulation and measurement
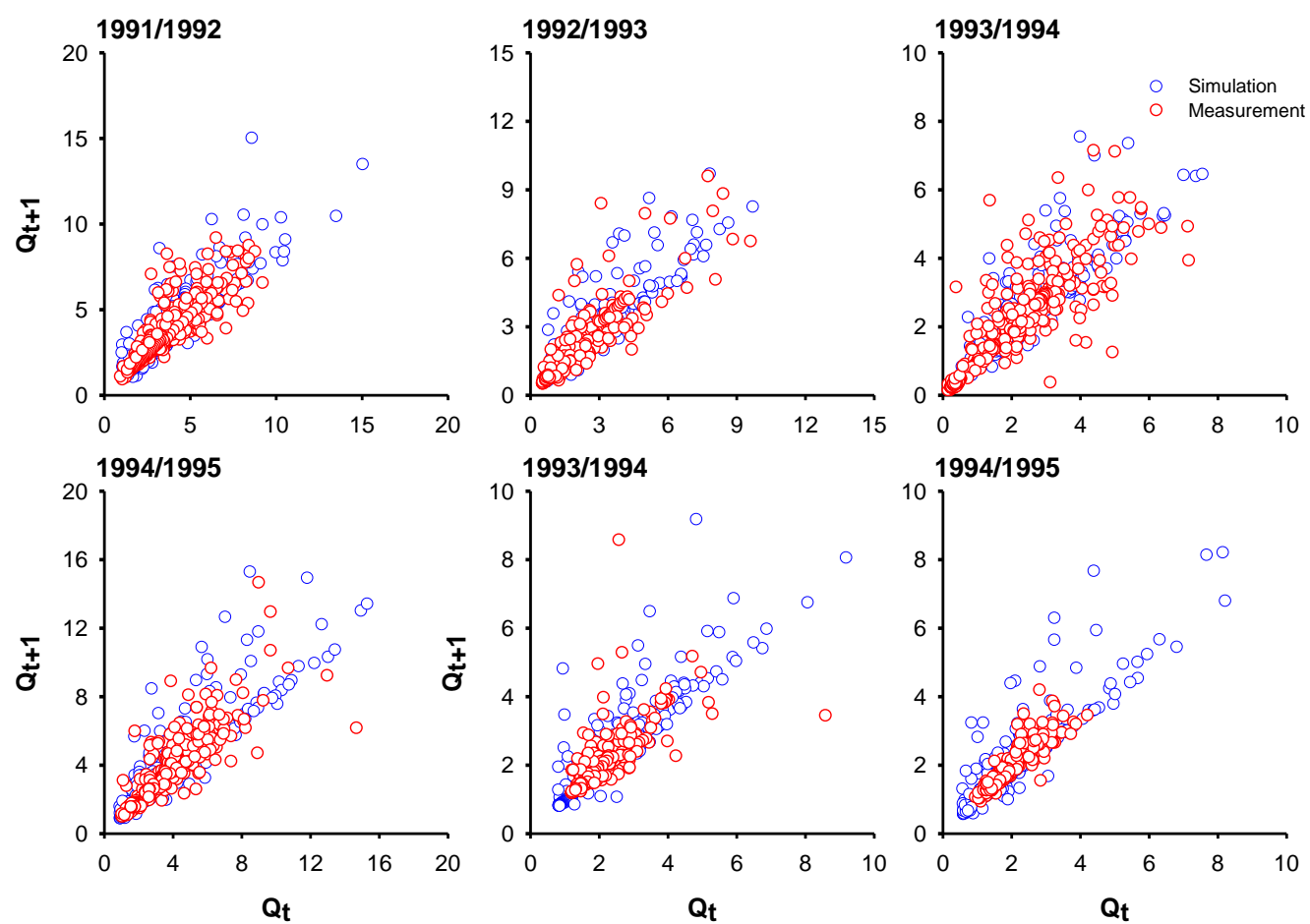

Figure 26. Flow persistence $Q_{t+1}$ versus $Q_{t}$ plots 

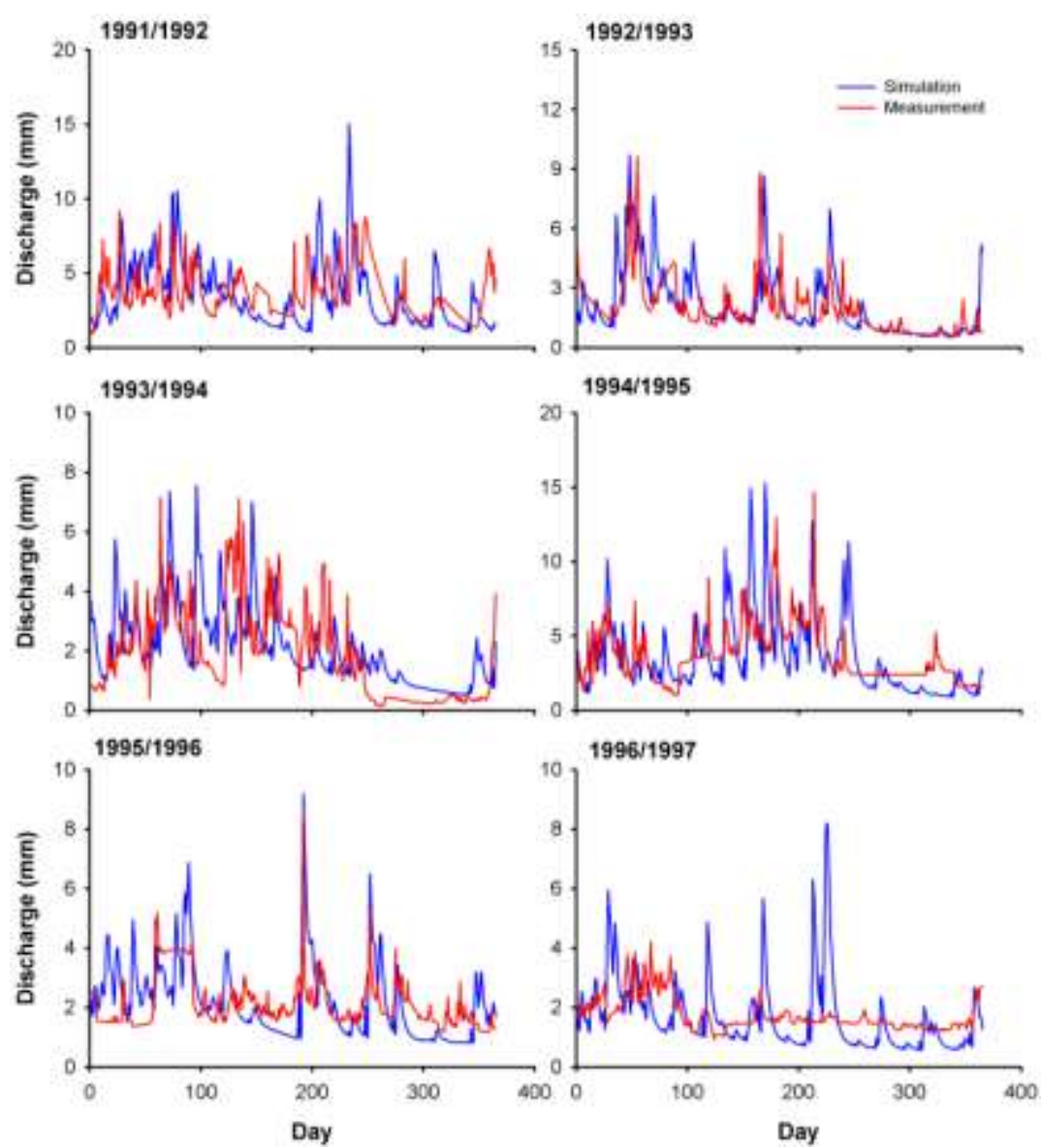

Figure 27. Hydrograph of simulation and measurement of discharge (mm)

Table 23. Monthly discharge performance test

\begin{tabular}{cccclll}
\hline Year & $\mathbf{n}$ & Biased (\%) & NSE & $\mathbf{r}$ & \multicolumn{1}{c}{ Biased (\%) } & \multicolumn{1}{c}{ NSE } \\
\hline $1991 / 1992$ & 12 & -10.28 & -0.92 & 0.62 & Good & Unsatisfactory \\
\hline $1992 / 1993$ & 12 & 5.69 & 0.66 & 0.91 & Very good & Good \\
\hline $1993 / 1994$ & 12 & 38.45 & 0.51 & 0.72 & Unsatisfactory & Satisfactory \\
\hline $1994 / 1995$ & 12 & -2.94 & 0.63 & 0.86 & Very good & Satisfactory \\
\hline $1995 / 1996$ & 12 & -0.51 & 0.28 & 0.74 & Very good & Unsatisfactory \\
\hline $1996 / 1997$ & 12 & -7.79 & -1.32 & 0.45 & Very good & Unsatisfactory \\
\hline
\end{tabular}

\section{Model performance on water balance}

The average water balance of the Krueng Peusangan watershed for 18 years simulation period is presented in Table 24. Total rainfall varies range $1317-2366 \mathrm{~mm}$. Evapotranspiration in the area is about $41 \%$ of annual rainfall. Run off in the area is about $39 \%$ of annual rainfall, while soil quick flow is almost none. The run off tend to increase and evapotranpiration tend to decrease for the last 20 years as the main effect of land cover change in the upper and lower part of the area (Figure 28), while the base flow and sub surface flow remain stable. 
Table 24. The summary of water balance $1991-2009$

\begin{tabular}{lrrrrrr}
\hline \multirow{2}{*}{ Parameters } & \multicolumn{2}{c}{ Min } & \multicolumn{2}{c}{ Average } & \multicolumn{2}{c}{ Max } \\
\cline { 2 - 8 } & mm & \% rainfall & mm & \% rainfall & mm & \% rainfall \\
\hline Precipitation & 1316.9 & & 1895.4 & & 2366.3 & \\
\hline Evapotranspiration & 581.5 & 44.2 & 774.0 & 40.8 & 962.2 & 40.7 \\
\hline RiverFlow (Observed) & 693.3 & 52.6 & 964.5 & 50.9 & 1335.0 & 56.4 \\
\hline Lake water Not release & 4.5 & 0.3 & 22.2 & 1.2 & 41.4 & 1.7 \\
\hline RiverFlow (Simulated): & 731.9 & 55.6 & 1116.0 & 58.9 & 1497.2 & 63.3 \\
\hline - RunOff & 357.9 & 27.2 & 733.6 & 38.7 & 1068.5 & 45.2 \\
\hline - SoilQFlow & 0.02 & 0.0 & 0.4 & 0.0 & 1.2 & 0.1 \\
\hline - BaseFlow & 229.0 & 17.4 & 340.1 & 17.9 & 421.0 & 17.8 \\
\hline - Lake OutFlow & 91.3 & 6.9 & 94.3 & 5.0 & 98.6 & 4.2 \\
\hline
\end{tabular}

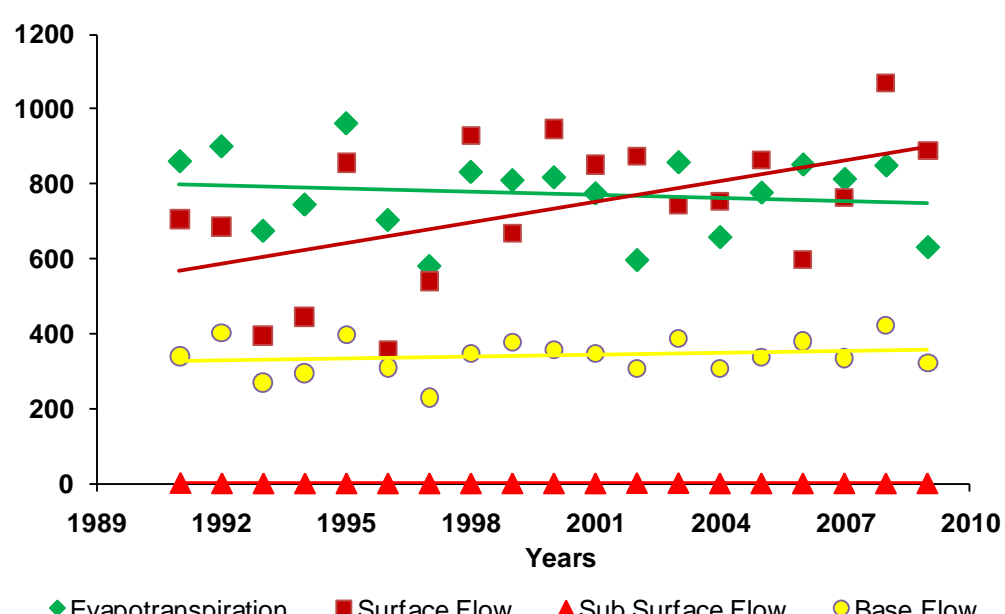

Figure 28. Water balance from $1991-2009(\mathrm{~mm})$

\section{Analysis on Indicators of Watershed Functions}

The total water yield as a fraction of total rainfall tends to increase with average value 0.59 (Table 25 ) for the last 20 years as the main effect of land cover change and rainfall variation. The effect of rainfall variation and land cover change can be simply assessed using indicator of watershed function and it is expressed to discharge fraction.

The run off (surface flow) and highest month fraction has positive correlation to total water yield with average value 0.38 and 1.92 , respectively. The lowest month fraction, buffering indicator, buffering indicator relative and buffering peak event have negative correlation to total water yield. The other indicators tended quite stable to the discharge fraction over the years (Figure 29). 

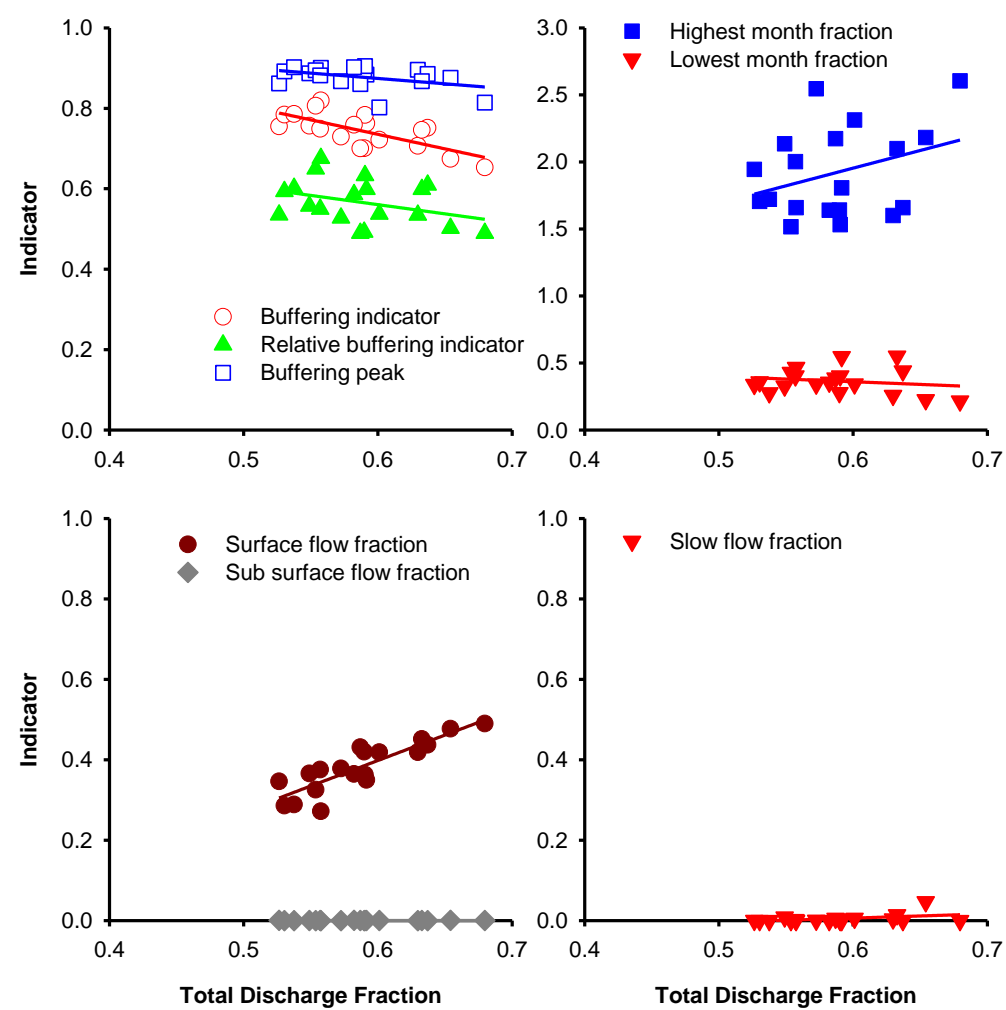

Figure 29. Indicator of watershed function for the last 18 years

Table 25. The summary of watershed indicator $1991-2009$

\begin{tabular}{llccc}
\hline No. & \multicolumn{1}{c}{ Indicators } & Min & Average & Max \\
\hline 1.1 & Total discharge fraction & 0.526 & 0.587 & 0.680 \\
\hline 2.1 & Buffering indicator & 0.653 & 0.744 & 0.819 \\
\hline 2.2 & Relative buffering indicator & 0.489 & 0.566 & 0.676 \\
\hline 2.3 & Buffering peak events & 0.802 & 0.878 & 0.905 \\
\hline 2.4 & Highest monthly discharge relative to mean rainfall & 1.516 & 1.920 & 2.605 \\
\hline 2.5 & Surface flow fraction & 0.272 & 0.382 & 0.490 \\
\hline 2.6 & Sub surface flow fraction & 0.000 & 0.000 & 0.001 \\
\hline 3.1 & Slow flow fraction & 0.000 & 0.005 & 0.047 \\
\hline 3.2 & Lowest monthly discharge relative to mean rainfall & 0.215 & 0.365 & 0.550 \\
\hline
\end{tabular}

\subsubsection{Model scenarios}

\section{Water balance}

Water balance of various explored scenarios is presented in Table 26 and Figure 30 . After 10 years simulation, there was no significant different on water balance between the first three scenarios, it is related to the small area $(10-15 \%$ of total area) that converted to tree based system. However, the increasing of tree cover contributes to the decreasing of small amount or river flow compared to BAU condition. 
The significant change is found in scenario 4 and 5 . In scenario 5 where reforestation is the main figure in all sub catchments, evapotranspiration was increase about $50 \%$ and river discharge was decrease about $25 \%$. The same trend was also found in scenario 4 where monoculture crop and tree were converted to complex mixed tree crop; reforestation in open area and logged over forest, but the increasing of evapotranspiration and decreasing of river discharge is not as high as those scenario 5. There is also a slight increase in soil base flow for both scenarios. It is imply that there is transfer of runoff into soil base flow. Thus, the increase of tree cover in the landscape suggest can prevent flooding as well as abrasion during high rainfall events. However, the increase of tree cover did not change the amount of soil quick flow in any scenarios. On the other hand, the lake volume is continuing decrease in any scenarios (Table 27).

Table 26. The summary of water balance for each scenario at year 2019

\begin{tabular}{lrrrrrrr}
\hline \multirow{2}{*}{ Parameters } & \multicolumn{7}{c}{ Scenarios } \\
\cline { 2 - 8 } & Actual & BAU & $\mathbf{1}$ & $\mathbf{2}$ & $\mathbf{3}$ & $\mathbf{4}$ & $\mathbf{5}$ \\
\hline Precipitation & 1885.7 & 1885.7 & 1885.7 & 1885.7 & 1885.7 & 1885.7 & 1885.7 \\
\hline Evapotranspiration & 745.8 & 727.3 & 755.4 & 780.0 & 789.9 & 850.6 & 998.1 \\
\hline Lake water not release & 19.7 & 19.9 & 17.3 & 20.6 & 18.2 & 10.1 & 9.1 \\
\hline RiverFlow (Simulated) & 1109.2 & 1127.5 & 1100.6 & 1080.8 & 1072.3 & 1014.8 & 901.7 \\
\hline - RunOff & 756.4 & 780.2 & 739.3 & 758.4 & 741.8 & 617.4 & 498.3 \\
\hline - SoilQFlow & 0.0 & 0.0 & 0.0 & 0.0 & 0.0 & 0.03 & 0.0 \\
\hline - BaseFlow & 325.0 & 320.4 & 331.5 & 288.1 & 293.6 & 356.0 & 345.5 \\
\hline - Lake OutFlow & 87.6 & 87.6 & 87.6 & 87.6 & 87.6 & 87.6 & 87.6 \\
\hline
\end{tabular}

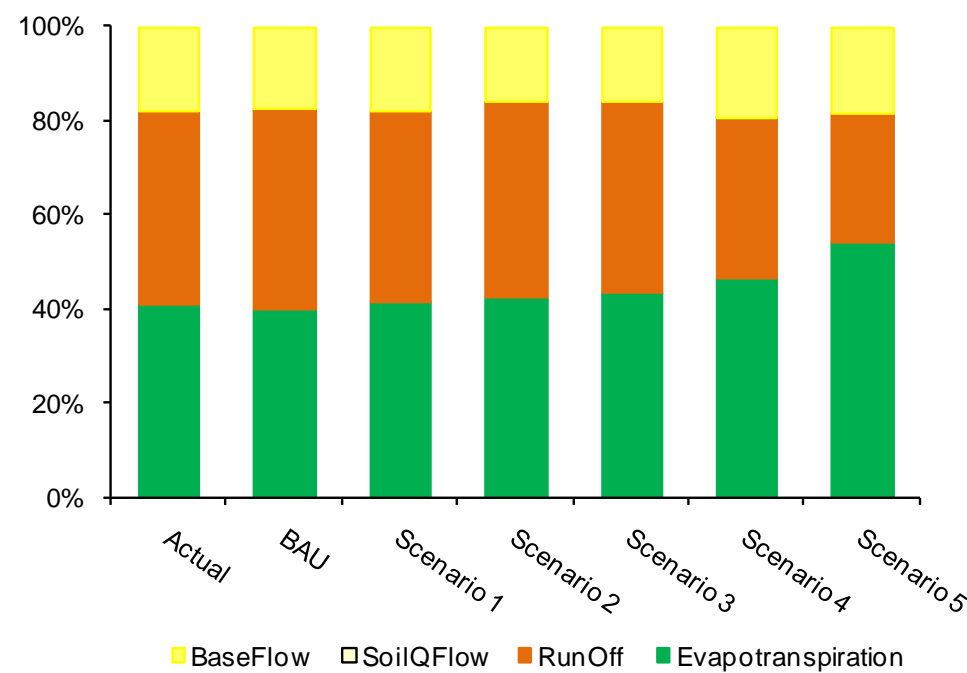

Figure 30. Water balance for each scenario compared to the 2009 condition

Tabel 27. Lake volume in any scenarios $\left(\mathrm{m}^{3}\right)$

\begin{tabular}{lccc}
\hline Scenarios & $\mathbf{2 0 0 0}$ & $\mathbf{2 0 1 9}$ & Different \\
\hline BAU & $2,525,823,620$ & $2,358,279,443$ & $167,544,177(6.63)$ \\
\hline 1 & $2,525,823,620$ & $2,356,547,397$ & $169,276,223(7.02)$ \\
\hline 2 & $2,525,823,620$ & $2,356,227,820$ & $169,595,801(6.70)$ \\
\hline 3 & $2,525,823,620$ & $2,355,689,519$ & $170,134,101(6.71)$ \\
\hline 4 & $2,525,823,620$ & $2,353,643,535$ & $172,180,085(6.74)$ \\
\hline 5 & $2,525,823,620$ & $2,348,469,103$ & $177,354,517(6.82)$ \\
\hline
\end{tabular}




\section{Analysis on Indicators of Watershed Functions}

Change in watershed functions due to land cover change of various explored scenarios is presented in Table 28. The watershed functions of the first three scenarios still within the variation of BAU scenario. Significant change found in surface flow fraction and total discharge fraction of scenarios 4 and 5. This result, confirm that the increasing of tree cover in the landscape can prevent flash flood as well as abrasion during high rainfall events.

Figure 31 presents the buffering indicator and it is expressed to its frequency. Compared to BAU, shift in curve of buffering indicator is $0.8 \%, 3.4 \%$ and $6.6 \%$, respectively for scenario 1,4 and 5 , while its range between the best and the worse years is $14.9 \%, 15 \%$ and $13 \%$, respectively for scenario 1, 4 and 5. The primary change for the better land use will help avoid 10\%, 15\% and 36\% (scenario 1, 4 and 5, respectively) of worst years under BAU.

Table 28. The summary of watershed indicator $2000-2019$

\begin{tabular}{|c|c|c|c|c|c|c|c|c|}
\hline \multirow{2}{*}{ No. } & \multirow{2}{*}{ Indicators } & \multirow{2}{*}{2019} & \multicolumn{6}{|c|}{ Scenarios } \\
\hline & & & BAU & 1 & 2 & 3 & 4 & 5 \\
\hline 1.1 & Total discharge fraction & 0.59 & 0.60 & 0.58 & 0.57 & 0.57 & 0.54 & 0.48 \\
\hline 2.1 & Buffering indicator & 0.79 & 0.79 & 0.80 & 0.79 & 0.79 & 0.82 & 0.85 \\
\hline 2.2 & Relative buffering indicator & 0.65 & 0.64 & 0.65 & 0.64 & 0.64 & 0.66 & 0.68 \\
\hline 2.3 & Buffering peak events & 0.87 & 0.87 & 0.87 & 0.87 & 0.87 & 0.88 & 0.89 \\
\hline 2.4 & $\begin{array}{l}\text { Highest monthly discharge relative to } \\
\text { mean rainfall }\end{array}$ & 1.59 & 1.60 & 1.58 & 1.60 & 1.59 & 1.54 & 1.48 \\
\hline 2.5 & Surface flow fraction & 0.40 & 0.41 & 0.39 & 0.40 & 0.39 & 0.33 & 0.26 \\
\hline 2.6 & Sub surface flow fraction & 0.00 & 0.00 & 0.00 & 0.00 & 0.00 & 0.00 & 0.00 \\
\hline 3.1 & Slow flow fraction & 0.19 & 0.18 & 0.20 & 0.17 & 0.18 & 0.21 & 0.21 \\
\hline 3.2 & $\begin{array}{l}\text { Lowest monthly discharge relative to } \\
\text { mean rainfall }\end{array}$ & 0.53 & 0.52 & 0.53 & 0.52 & 0.52 & 0.53 & 0.53 \\
\hline
\end{tabular}

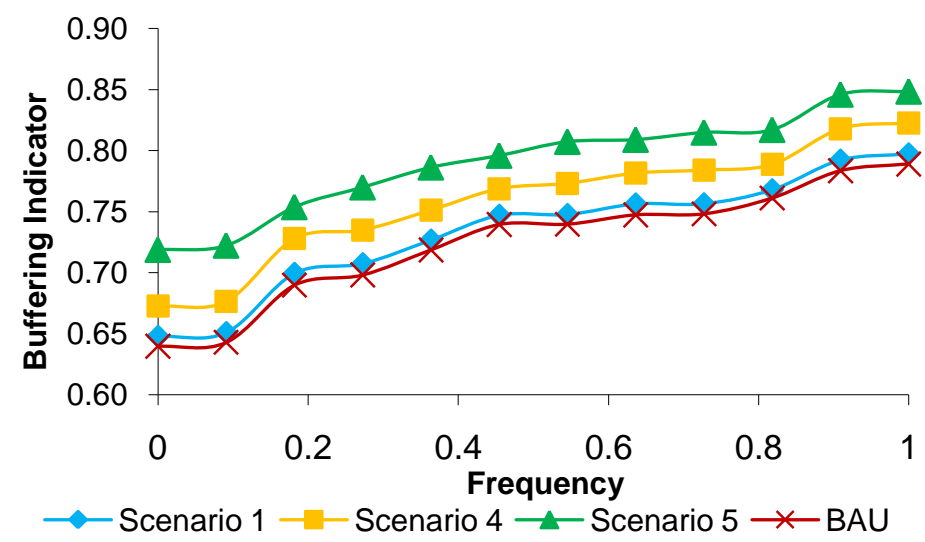

Figure 31. Buffering indicator of scenario 1, 4 and 5 expressed to its frequency 


\section{Discussion}

In general, the local community and stakeholder perceptions within the three main locations (upstream, midstream and downstream) on hydrological problem are similar: flooding, riverbank collapse or abrasion and soil erosion/sedimentation are the main symptoms and the main causal factors are deforestation/logging and land conversion (Figure 12 - 15). The result of land cover change analysis and GenRiver model simulation confirm effects of land conversion in the context of local climate, its variability and the topography of the area.

The main four types of land cover change are (1) decreasing area of forest cover, (2) increasing area of coffee agroforest in the upper and middle catchment of the area, (3) increasing area of oil palm in the lower catchment of the area, and (4) decrease of pine forest area (Figure 21 - 22). The highest rate of deforestation occurred in 1990 - 2000 in the upper and lower catchment of the area and clearly slowed down in 2000 - 2009. The agroforest type of cover mainly derived from natural forest in the middle of the catchment (Figure 23 - 24).

The decrease of tree cover in the landscape for the last 20 years is significantly increases the total water yield as a fraction of total rainfall. The highest contribution to this additional flow is run off (surface flow) especially during high rainfall events as shown in Figure 30. The highest month fraction has positive correlation to total water yield.

The perceptions of local community members and other key stakeholders on what should be done to manage the current situation of the Krueng Peusangan watershed is correspond to the result of model scenarios. It is listed on Table 29 and 30. Based on perceptions of local community members and other key stakeholders confirmed with model simulation result, an increase of tree cover in the landscape can reduce the total water yield as implication of the transfer of surface runoff into soil base flow during high rainfall events. Shifts in the pathway that water takes to reach the river, from current surface flow to an increase in base flow will depend on the rate of recovery of soil physical conditions.

Reforestation; planting valuable trees in mixed tree crop, coffee agroforest and riparian area are strongly recommended by local community. It is seen as feasible solutions. Some native fruit trees (avocado/Persea americana, durian/Durio zibetinus, jackfruit/Artocarpus heterophyllus, guava/Psidium guava, jambu air, aren/nira) and other trees species jeumpa/Michelia champaca LINN, pine, temor/Arenga pinnata, beringin/Ficus Sp, light wood (temung/Clausena excavata BURM.f., pungkih), dedalu, daling are the locally known by community and some stakeholder that might have good value on water preservation.

More in-depth study on critical point of abrasion and needs on 'bronjong' establishment as well as planting valuable trees in riparian area. Waru (Hisbiscus teleaceus) and bamboo were performing appropriate vegetation in riverbank, however would need some elaboration on other economic valuable vegetation, which has good ecological function.

While local community members seek location-specific solutions, public/policy stakeholders refer to generic solutions in the form of forest protection and rehabilitation through reforestation as important actions in responding to floods, soil erosion and riverbank abrasion. The degree to which hydrological functions can be improved within the economically important coffee agroforestry 
systems, rather than by replacing these by 'reforestation' efforts will have to be a major issue in local discussions on improving natural resource management.

Table 29. Local community perception on some action

\begin{tabular}{|c|c|c|c|c|}
\hline Period & Provider & Activities & Purpose & Beneficiaries \\
\hline \multirow[b]{2}{*}{$\begin{array}{l}\text { Short } \\
\text { term }\end{array}$} & \multirow{2}{*}{$\begin{array}{l}\text { Downstream } \\
\text { community } \\
\text { along the } \\
\text { river }\end{array}$} & - $\quad$ Build 'bronjong' & \multirow[b]{2}{*}{$\begin{array}{l}\text { Reducing the impact of } \\
\text { abrasion }\end{array}$} & \multirow{2}{*}{$\begin{array}{l}\text { Downstream } \\
\text { community along the } \\
\text { river }\end{array}$} \\
\hline & & - $\quad$ Planting waru and bamboo & & \\
\hline \multirow{10}{*}{ Long term } & \multirow{3}{*}{$\begin{array}{l}\text { Downstream } \\
\text { community }\end{array}$} & - Better waste management & \multirow{10}{*}{$\begin{array}{l}\text { Reducing the impact of } \\
\text { floods and abrasion } \\
\text { Enrich water quality } \\
\text { Reducing sedimentation }\end{array}$} & \multirow{3}{*}{$\begin{array}{l}\text { - Downstream } \\
\text { community along } \\
\text { the river } \\
\text { - Private } \\
\text { companies in } \\
\text { Lhokseumawe }\end{array}$} \\
\hline & & $\begin{array}{l}\text { - Planting valuable trees on } \\
\text { 'kebun campur', such as } \\
\text { nutmeg (Myristica fragrans), } \\
\text { rambutan (Nephelium } \\
\text { lappaceum), rubber (Hevea } \\
\text { brasiliensis), durian, etc }\end{array}$ & & \\
\hline & & $\begin{array}{l}\text { - } \quad \text { Planting valuable trees in } \\
\text { riparian area }\end{array}$ & & \\
\hline & \multirow{3}{*}{$\begin{array}{l}\text { Upstream } \\
\text { community }\end{array}$} & $\begin{array}{l}\text { Better waste management } \\
\text { Planting valuable trees on } \\
\text { 'kebun campur', such as } \\
\text { nutmeg, rambutan, rubber, } \\
\text { durian, etc }\end{array}$ & & \multirow{7}{*}{$\begin{array}{l}\text { All community } \\
\text { Private } \\
\text { companies in } \\
\text { Lhokseumawe }\end{array}$} \\
\hline & & $\begin{array}{l}\text { - } \quad \text { Planting valuable trees on } \\
\text { coffee system, such as } \\
\text { nutmeg, rambutan, durian, etc }\end{array}$ & & \\
\hline & & $\begin{array}{l}\text { - } \quad \text { Planting valuable trees in } \\
\text { riparian area }\end{array}$ & & \\
\hline & \multirow{4}{*}{$\begin{array}{l}\text { Upstream } \\
\text { community - } \\
\text { surrounding } \\
\text { Lake Laut } \\
\text { Tawar }\end{array}$} & $\begin{array}{l}\text { - Planting valuable trees on } \\
\text { 'kebun campur', such as such } \\
\text { as nutmeg, rambutan, rubber, } \\
\text { durian, etc }\end{array}$ & & \\
\hline & & $\begin{array}{l}\text { Planting valuable trees on } \\
\text { coffee system, such as such } \\
\text { as nutmeg, rambutan, durian, } \\
\text { etc }\end{array}$ & & \\
\hline & & $\begin{array}{ll}\text { - } & \text { Practicing steep land } \\
\text { conservation management }\end{array}$ & & \\
\hline & & $\begin{array}{l}\text { - Replanting pines areas with } \\
\text { pines }\end{array}$ & & \\
\hline
\end{tabular}

Enhancing local capacity and environment awareness of fishery community in practicing floating net, pen culture, and environmental friendly fishing both in river and Lake Laut Tawar, will be very important to reduce the pressure from fishing activity that lead to decreasing of water quality and biodiversity. Environment educations for young generation are also mentioned by local NGOS concern to environment protection as one of alternative to improve household and tourism waste management in riparian area as well as in Lake Laut Tawar area. 
Table 30. Stakeholder perception on hydrological problems and the appropriate action

\begin{tabular}{|c|c|c|c|c|}
\hline Stakeholder & $\begin{array}{l}\text { Main hydrological } \\
\text { problems }\end{array}$ & $\begin{array}{l}\text { Perception on } \\
\text { causal factor }\end{array}$ & What needs to be done? & $\begin{array}{c}\text { What resources will } \\
\text { they commit }\end{array}$ \\
\hline $\begin{array}{l}\text { Provincial } \\
\text { government }\end{array}$ & $\begin{array}{l}\text { Flood prone area } \\
\text { Siltation }\end{array}$ & $\begin{array}{l}\text { Land clearing } \\
\text { Logging }\end{array}$ & $\begin{array}{l}\text { Balancing ecological, socio, } \\
\text { and economical aspects, not } \\
\text { only focus on economical }\end{array}$ & \multirow{5}{*}{$\begin{array}{l}\text { Commitment from the } \\
\text { districts where } \\
\text { Peusangan watershed } \\
\text { importants } \\
\text { One river one } \\
\text { management }\end{array}$} \\
\hline BPKEL & Flood & Forest clearing & Forest protection & \\
\hline $\begin{array}{l}\text { Bener Meriah } \\
\text { government }\end{array}$ & $\begin{array}{l}\text { Flood } \\
\text { Erosion/Abrasion }\end{array}$ & $\begin{array}{l}\text { Forest clearing } \\
\text { Logging }\end{array}$ & $\begin{array}{l}\text { Critical land rehabilitation } \\
\text { Non timber forest product } \\
\text { development } \\
\text { Illegal logging alleviation }\end{array}$ & \\
\hline $\begin{array}{l}\text { Bappeda Aceh } \\
\text { Tengah }\end{array}$ & $\begin{array}{l}\text { Water flow } \\
\text { instability } \\
\text { Flood }\end{array}$ & $\begin{array}{l}\text { Large critical } \\
\text { land area ( } 67 \% \\
\text { from } 53258 \mathrm{ha})\end{array}$ & $\begin{array}{l}\text { Forest protection } \\
\text { Forest rehabilitation }\end{array}$ & \\
\hline $\begin{array}{l}\text { Forestry } \\
\text { department }\end{array}$ & $\begin{array}{l}\text { Flood } \\
\text { Erosion/Abrasion } \\
\text { Water flow } \\
\text { instability }\end{array}$ & $\begin{array}{l}\text { Forest clearing } \\
\text { Logging } \\
\text { Wild forage }\end{array}$ & $\begin{array}{l}\text { Critical land rehabilitation } \\
\text { Forest protection }\end{array}$ & \\
\hline
\end{tabular}




\section{Conclusion}

In general, the local community and stakeholder perceptions within the three main locations on hydrological problem are similar: flooding, riverbank collapse or abrasion and soil erosion/sedimentation are the main symptoms and the main causal factors are deforestation/logging and land conversion. The result of land cover change analysis and GenRiver model simulation confirmed effects of land conversion in the context of local climate: its variability and the topography of the area.

The decrease of tree cover in the landscape for the last 20 years significantly increased the total water yield as a fraction of total rainfall. The highest contribution to this additional flow is run off (surface flow) especially during high rainfall events. The highest monthly river flow fraction has a positive correlation to total water yield.

Based on perceptions of local community members and other key stakeholders confirmed with model simulation result, an increase of tree cover in the landscape prevent hydrological impacts as it can reduce the surface flow and increase base flow during high rainfall events. Shifts in the pathway that water takes to reach the river, from current surface flow to an increase in base flow will depend on the rate of recovery of soil physical conditions.

Finally we recommend to (1) follow-up studies on the effects of coffee agroforestry and other forest derived land uses on soil physical conditions, (2) explore types of tress that both has ecological and economical functions, and (3) design any rewards environmental services schemes that can accelerate the process of increasing tree cover. This scheme may benefit downstream communities in Krueng Peusangan watershed, including companies in Lhokseumawe. 


\section{References}

Jeanes K, van Noordwijk M, Joshi L, Widayati A, Farida and Leimona B. 2006. Rapid Hydrological Appraisal in the context of environmental service rewards. Bogor, Indonesia.World Agroforestry Centre - ICRAF, SEA Regional Office. 56 p.

Dixon HJ, Doores JW, Joshi L and Sinclair FL. 2001. Agroecological Knowledge Toolkit for Windows: methodological guidelines, computer software and manual for AKT5 School of

Agricultural and Forest Sciences, University of Wales, Bangor.

Muchlisin Z.A. 2008. Ikan depik yang terancam punah. Bulletin Leuser,6(17): 9-12

van Noordwijk M, Widodo RH, Farida A, Suyamto D, Lusiana B, Tanika L, and Khasanah N. 2010. GenRiver and FlowPer: Generic River Flow Persistence Models, User Manual Version 2.0. World Agroforestry Centre (ICRAF), Bogor, Indonesia.

van Noordwijk M, Farida, Saipothong P, et al.. 2006. Watershed functions in productive agricultural landscapes with trees. In: Garrity DP, Okono A, Grayson M and Parrott S,eds. World Agroforestry into the Future. Nairobi, Kenya. World Agroforestry Centre - ICRAF. P. 103-112.

van Noordwijk M, Widodo RH, Farida A, Suyamto D, Lusiana B, Tanika L, and Khasanah N. 2010. GenRiver and FlowPer: Generic River Flow Persistence Models, User Manual Version 2.0. World Agroforestry Centre (ICRAF), Bogor, Indonesia.

World Conservation Monitoring Centre 1996. Poropuntius tawarensis. In: IUCN 2009. IUCN Red List of Threatened Species. Version 2009.2. 〈www.iucnredlist.org>. Downloaded on 09 March 2010.

World Conservation Monitoring Centre 1996. Rasbora tawarensis. In: IUCN 2009. IUCN Red List of Threatened Species. Version 2009.2. <www.iucnredlist.org>. Downloaded on 09 March 2010.

WWF. 2008. Laporan Pertemuan Antar Pemerintah Kabupaten/Kota Dalam Rangka Pengelolaan Daerah Aliran Sungai (DAS) Peusangan Secara Kolaboratif dan Berkelanjutan. http://www.serambinews.com/news/view/24653/abrasi-krueng-peusangan-cemaskan-warga http://www.modusaceh.com/html/read/reportase/1224/mengais_rezeki_di_kreueng_peusangan. $\mathrm{html} /$

http://www.rapi0107.org/cetak.php?id=171 


\section{Appendixes}

\section{Appendix 1. Performance evaluation of rainfall simulator model}

1. Coefficient correlation analysis $(\mathrm{R})$

$$
\begin{gathered}
S_{x x}=\sum x^{2}-\frac{\left(\sum x\right)^{2}}{n} \\
S_{y y}=\sum y^{2}-\frac{\left(\sum y\right)^{2}}{n} \\
S_{x y}=\sum x y-\frac{\left(\sum x\right)\left(\sum y\right)}{n} \\
R=\frac{S_{x y}}{\sqrt{S_{x x} S_{y y}}}
\end{gathered}
$$

where, $\mathrm{x}$ is montly measured data, $\mathrm{y}$ is monthy predicted data and $\mathrm{n}$ is number of data. Value $>0.65$ is generarally viewed as satisfactory and value $\leq 0.65$ as unsatisfactory.

2. Bias analysis (Bias, \%)

$$
\text { Bias }=\frac{\sum\left(y_{o b s}-y_{\text {sim }}\right)}{\sum y_{\text {obs }}} \times 100 \%
$$

where, $\mathrm{y}_{\text {obs }}$ is montly measured data and $\mathrm{y}_{\text {sim }}$ is monthy predicted data. Performance evaluation criteria is presented as following Table.

\begin{tabular}{ll}
\hline Performance Rating & Bias (\%) \\
\hline Very Good & $\mid$ Bias $\mid<10$ \\
\hline Good & $10 \leq \mid$ Bias $\mid<15$ \\
\hline Satisfactory & $15 \leq \mid$ Bias $\mid<25$ \\
\hline Unsatisfactory & $25 \leq \mid$ Bias $\mid$ \\
\hline
\end{tabular}




\section{Appendix 2. Performance evaluation of GenRiver 2.0 model output}

The Nash-Sutcliffe efficiency (NSE) is a normalized statistic that determines the relative magnitude of the residual variance ("noise") compared to the measured data variance (Nash and Sutcliffe, 1970). NSE indicates how well the plot of observed versus simulated data fits the 1:1 line.

$$
N S E=1-\left[\frac{\sum_{i=1}^{n}\left(Y_{i}^{\text {obs }}-Y_{i}^{\text {sim }}\right)^{2}}{\sum_{i=1}^{n}\left(Y_{i}^{\text {obs }}-Y^{\text {mean }}\right)^{2}}\right]
$$

Where, $\mathrm{Y}_{\text {iobs }}$ is the observation for the constituent being evaluated, $\mathrm{Y}_{\text {isim }}$ is the simulated value for the constituent being evaluated, $Y_{\text {mean }}$ is the mean of observed data for the constituent being evaluated, and $\mathrm{n}$ is the total number of observations.

NSE ranges between $-\infty$ and 1.0 ( 1 inclusive), with NSE $=1$ being the optimal value. Values between 0.0 and 1.0 are generally viewed as acceptable levels of performance, whereas values $<0.0$ indicates that the mean observed value is a better predictor than the simulated value, which indicates unacceptable performance. Performance of the model result will be evaluated annually, and will be accepted when performed NSE criteria more than 0.50 as the following table (Moriasi, D.N. et. al., 2007).

\begin{tabular}{ll}
\hline Performance Rating & NSE \\
\hline Very good & $0.75<$ NSE $\leq 1.00$ \\
\hline Good & $0.65<$ NSE $\leq 0.75$ \\
\hline Satisfactory & $0.50<$ NSE $\leq 0.65$ \\
\hline Unsatisfactory & NSE $\leq 0.5$ \\
\hline
\end{tabular}




\section{Appendix 3. Indicator of watershed function}

Criteria and indicators of watershed hydrological functions that relevant to downstream stakeholders (Van Noordwijk, et al., 2006)

\begin{tabular}{|c|c|c|c|c|}
\hline Criteria & Indicator & Quantitative Indicator & $\begin{array}{l}\text { Site } \\
\text { Characteristics }\end{array}$ & Relevant for \\
\hline $\begin{array}{l}\text { Water } \\
\text { transmition }\end{array}$ & $\begin{array}{l}\text { Total water yield } \\
\text { (discharge) per unit } \\
\text { rainfall (TWY) }\end{array}$ & $\begin{array}{l}\qquad T W Y=\frac{Q}{A \times P} \\
\mathrm{Q}=\text { annual river flow } \\
\mathrm{A}=\text { total watershed area } \\
\mathrm{P}=\text { annual precipitation }\end{array}$ & $\begin{array}{l}\text { Annuall rainfall } \\
\left(\mathrm{mm}^{-1} \text { year }{ }^{-1}\right)\end{array}$ & $\begin{array}{l}\text { Downstream } \\
\text { water user }\end{array}$ \\
\hline \multirow[t]{5}{*}{$\begin{array}{l}\text { Buffering peak } \\
\text { rain event }\end{array}$} & $\begin{array}{l}\text { Buffering indicator for } \\
\text { peak flows given } \\
\text { peak rain even }(\mathrm{BI})\end{array}$ & $\begin{aligned} B I & =1-\frac{Q_{\text {obs_Avg }}}{A x P_{\text {obs_Avg }}} \\
P_{\text {obs_Avg }} & =\sum \max \left(P-P_{\text {mean }}, 0\right) \\
Q_{\text {obs_Avg }} & =\sum \max \left(Q-Q_{\text {mean }}, 0\right)\end{aligned}$ & Geomorphology & $\begin{array}{l}\text { Communities } \\
\text { living along } \\
\text { the river and } \\
\text { in flood plains }\end{array}$ \\
\hline & $\begin{array}{l}\text { Relative buffering } \\
\text { indicator, adjusted for } \\
\text { relative water yield } \\
\text { (RBI) }\end{array}$ & $R B I=1-\left(\frac{P_{\text {mean }}}{Q_{\text {mean }}} x \frac{Q_{\text {obs_Avg }}}{P_{\text {obs_Avg }}}\right)$ & & \\
\hline & $\begin{array}{l}\text { Buffering peak event } \\
\text { (BPE) }\end{array}$ & 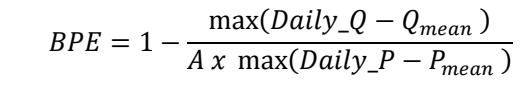 & & \\
\hline & $\begin{array}{l}\text { Fraction of total river } \\
\text { discharge derived } \\
\text { from surface quick } \\
\text { flow (run off) }\end{array}$ & Direct output from model & & \\
\hline & $\begin{array}{l}\text { Fraction of total river } \\
\text { discharge derived } \\
\text { from soil quick flow }\end{array}$ & Direct output from model & & \\
\hline \multirow[t]{2}{*}{$\begin{array}{l}\text { Gradual water } \\
\text { release (water } \\
\text { availability } \\
\text { during dry } \\
\text { season) }\end{array}$} & \multicolumn{2}{|c|}{$\begin{array}{l}\text { Lowest of monthly river discharge totals relative to mean monthly } \\
\text { rainfall }\end{array}$} & $\begin{array}{l}\text { Soil type and } \\
\text { characteristics }\end{array}$ & $\begin{array}{l}\text { Communities } \\
\text { who do not } \\
\text { own water } \\
\text { harvesting/st } \\
\text { oring systems } \\
\text { (lake, } \\
\text { embung) }\end{array}$ \\
\hline & $\begin{array}{l}\text { Fraction of } \\
\text { dishcharge drived } \\
\text { from slow flow }(>1 \\
\text { day after rain event) }\end{array}$ & Direct output from model & & \\
\hline
\end{tabular}

Note: $Q\left(\mathrm{~mm} \cdot\right.$ day $\left.^{-1}\right)=\left\{\left[\left(\mathrm{m}^{3} \cdot \mathrm{sec}^{-1}\right) \times 24\right.\right.$ hour $\times 3600$ sec.hour $\left.\left.\left.{ }^{-1}\right] /\left[\mathrm{A}\left(\mathrm{km}^{2}\right) \times 10^{6} \mathrm{~m}^{2} \cdot \mathrm{km}-2\right)\right]\right\} \times 10^{3}\left(\mathrm{~mm} \cdot \mathrm{m}^{-1}\right)$ 


\section{WORKING PAPERS IN THIS SERIES}

2005

1. Agroforestry in the drylands of eastern Africa: a call to action

2. Biodiversity conservation through agroforestry: managing tree species diversity within a network of community-based, nongovernmental, governmental and research organizations in western Kenya.

3. Invasion of prosopis juliflora and local livelihoods: Case study from the Lake Baringo area of Kenya

4. Leadership for change in farmers organizations: Training report: Ridar Hotel, Kampala, 29th March to 2nd April 2005.

5. Domestication des espèces agroforestières au Sahel : situation actuelle et perspectives

6. Relevé des données de biodiversité ligneuse: Manuel du projet biodiversité des parcs agroforestiers au Sahel

7. Improved land management in the Lake Victoria Basin: TransVic Project's draft report.

8. Livelihood capital, strategies and outcomes in the Taita hills of Kenya

9. Les espèces ligneuses et leurs usages: Les préférences des paysans dans le Cercle de Ségou, au Mali

10. La biodiversité des espèces ligneuses: Diversité arborée et unités de gestion du terroir dans le Cercle de Ségou, au Mali

\section{6}

11. Bird diversity and land use on the slopes of Mt. Kilimanjaro and the adjacent plains, Tanzania

12. Water, women and local social organization in the Western Kenya Highlands

13. Highlights of ongoing research of the World Agroforestry Centre in Indonesia

14. Prospects of adoption of tree-based systems in a rural landscape and its likely impacts on carbon stocks and farmers' welfare: The FALLOW Model Application in Muara Sungkai, Lampung, Sumatra, in a 'Clean Development Mechanism' context

15. Equipping integrated natural resource managers for healthy Agroforestry landscapes.

17. Agro-biodiversity and CGIAR tree and forest science: approaches and examples from Sumatra.

18. Improving land management in eastern and southern Africa: A review of policies.

19. Farm and household economic study of Kecamatan Nanggung, Kabupaten Bogor, Indonesia: A socio-economic base line study of Agroforestry innovations and livelihood enhancement.

20. Lessons from eastern Africa's unsustainable charcoal business.

21. Evolution of RELMA's approaches to land management: Lessons from two decades of research and development in eastern and southern Africa

22. Participatory watershed management: Lessons from RELMA's work with farmers in eastern Africa.

23. Strengthening farmers' organizations: The experience of RELMA and ULAMP.

24. Promoting rainwater harvesting in eastern and southern Africa. 
25. The role of livestock in integrated land management.

26. Status of carbon sequestration projects in Africa: Potential benefits and challenges to scaling up.

27. Social and Environmental Trade-Offs in Tree Species Selection: A Methodology for Identifying Niche Incompatibilities in Agroforestry [Appears as AHI Working Paper no. 9]

28. Managing tradeoffs in agroforestry: From conflict to collaboration in natural resource management. [Appears as AHI Working Paper no. 10]

29. Essai d'analyse de la prise en compte des systemes agroforestiers pa les legislations forestieres au Sahel: Cas du Burkina Faso, du Mali, du Niger et du Senegal.

30. Etat de la recherche agroforestière au Rwanda etude bibliographique, période 1987-2003

\section{7}

31. Science and technological innovations for improving soil fertility and management in Africa: A report for NEPAD's Science and Technology Forum.

32. Compensation and rewards for environmental services.

33. Latin American regional workshop report compensation.

34. Asia regional workshop on compensation ecosystem services.

35. Report of African regional workshop on compensation ecosystem services.

36. Exploring the inter-linkages among and between compensation and rewards for ecosystem services CRES and human well-being

37. Criteria and indicators for environmental service compensation and reward mechanisms: realistic, voluntary, conditional and pro-poor

38. The conditions for effective mechanisms of compensation and rewards for environmental services.

39. Organization and governance for fostering Pro-Poor Compensation for Environmental Services.

40. How important are different types of compensation and reward mechanisms shaping poverty and ecosystem services across Africa, Asia \& Latin America over the Next two decades?

41. Risk mitigation in contract farming: The case of poultry, cotton, woodfuel and cereals in East Africa.

42. The RELMA savings and credit experiences: Sowing the seed of sustainability

43. Yatich J., Policy and institutional context for NRM in Kenya: Challenges and opportunities for Landcare.

44. Nina-Nina Adoung Nasional di So! Field test of rapid land tenure assessment (RATA) in the Batang Toru Watershed, North Sumatera.

45. Is Hutan Tanaman Rakyat a new paradigm in community based tree planting in Indonesia?

46. Socio-Economic aspects of brackish water aquaculture (Tambak) production in Nanggroe Aceh Darrusalam.

47. Farmer livelihoods in the humid forest and moist savannah zones of Cameroon.

48. Domestication, genre et vulnérabilité : Participation des femmes, des Jeunes et des catégories les plus pauvres à la domestication des arbres agroforestiers au Cameroun.

49. Land tenure and management in the districts around Mt Elgon: An assessment presented to the Mt Elgon ecosystem conservation programme. 
50. The production and marketing of leaf meal from fodder shrubs in Tanga, Tanzania: A propoor enterprise for improving livestock productivity.

51. Buyers Perspective on Environmental Services (ES) and Commoditization as an approach to liberate ES markets in the Philippines.

52. Towards Towards community-driven conservation in southwest China: Reconciling state and local perceptions.

53. Biofuels in China: An Analysis of the Opportunities and Challenges of Jatropha curcas in Southwest China.

54. Jatropha curcas biodiesel production in Kenya: Economics and potential value chain development for smallholder farmers

55. Livelihoods and Forest Resources in Aceh and Nias for a Sustainable Forest Resource Management and Economic Progress

56. Agroforestry on the interface of Orangutan Conservation and Sustainable Livelihoods in Batang Toru, North Sumatra.

57. Assessing Hydrological Situation of Kapuas Hulu Basin, Kapuas Hulu Regency, West Kalimantan.

58. Assessing the Hydrological Situation of Talau Watershed, Belu Regency, East Nusa Tenggara.

59. Kajian Kondisi Hidrologis DAS Talau, Kabupaten Belu, Nusa Tenggara Timur.

60. Kajian Kondisi Hidrologis DAS Kapuas Hulu, Kabupaten Kapuas Hulu, Kalimantan Barat.

61. Lessons learned from community capacity building activities to support agroforest as sustainable economic alternatives in Batang Toru orang utan habitat conservation program (Martini, Endri et al.)

62. Mainstreaming Climate Change in the Philippines.

63. A Conjoint Analysis of Farmer Preferences for Community Forestry Contracts in the Sumber Jaya Watershed, Indonesia.

64. The highlands: a shared water tower in a changing climate and changing Asia

65. Eco-Certification: Can It Deliver Conservation and Development in the Tropics.

66. Designing ecological and biodiversity sampling strategies. Towards mainstreaming climate change in grassland management.

67. Towards mainstreaming climate change in grassland management policies and practices on the Tibetan Plateau

68. An Assessment of the Potential for Carbon Finance in Rangelands

69 ECA Trade-offs Among Ecosystem Services in the Lake Victoria Basin.

69. The last remnants of mega biodiversity in West Java and Banten: an in-depth exploration of RaTA (Rapid Land Tenure Assessment) in Mount Halimun-Salak National Park Indonesia

70. Le business plan d'une petite entreprise rurale de production et de commercialisation des plants des arbres locaux. Cas de quatre pépinières rurales au Cameroun.

71. Les unités de transformation des produits forestiers non ligneux alimentaires au Cameroun. Diagnostic technique et stratégie de développement Honoré Tabuna et Ingratia Kayitavu.

72. Les exportateurs camerounais de safou (Dacryodes edulis) sur le marché sous régional et international. Profil, fonctionnement et stratégies de développement.

73. Impact of the Southeast Asian Network for Agroforestry Education (SEANAFE) on agroforestry education capacity.

74. Setting landscape conservation targets and promoting them through compatible land use in the Philippines. 
75. Review of methods for researching multistrata systems.

76. Study on economical viability of Jatropha curcas L. plantations in Northern Tanzania assessing farmers' prospects via cost-benefit analysis

77. Cooperation in Agroforestry between Ministry of Forestry of Indonesia and International Center for Research in Agroforestry

78. "China's bioenergy future. an analysis through the Lens if Yunnan Province

79. Land tenure and agricultural productivity in Africa: A comparative analysis of the economics literature and recent policy strategies and reforms

80. Boundary organizations, objects and agents: linking knowledge with action in Agroforestry watersheds

81. Reducing emissions from deforestation and forest degradation (REDD) in Indonesia: options and challenges for fair and efficient payment distribution mechanisms

2009

82. Mainstreaming climate change into agricultural education: challenges and perspectives

83. Challenging conventional mindsets and disconnects in conservation: the emerging role of eco-agriculture in Kenya's landscape mosaics

84. Lesson learned RATA garut dan bengkunat: suatu upaya membedah kebijakan pelepasan kawasan hutan dan redistribusi tanah bekas kawasan hutan

85. The emergence of forest land redistribution in Indonesia

86. Commercial opportunities for fruit in Malawi

87. Status of fruit production processing and marketing in Malawi

88. Fraud in tree science

89. Trees on farm: analysis of global extent and geographical patterns of agroforestry

90. The springs of Nyando: water, social organization and livelihoods in Western Kenya

91. Building capacity toward region-wide curriculum and teaching materials development in agroforestry education in Southeast Asia

92. Overview of biomass energy technology in rural Yunnan (Chinese - English abstract)

93. A pro-growth pathway for reducing net GHG emissions in China

94. Analysis of local livelihoods from past to present in the central Kalimantan Ex-Mega Rice Project area

95. Constraints and options to enhancing production of high quality feeds in dairy production in Kenya, Uganda and Rwanda

\section{0}

96. Agroforestry education in the Philippines: status report from the Southeast Asian Network for Agroforestry Education (SEANAFE)

97. Economic viability of Jatropha curcas L. plantations in Northern Tanzania- assessing farmers' prospects via cost-benefit analysis.

98. Hot spot of emission and confusion: land tenure insecurity, contested policies and competing claims in the central Kalimantan Ex-Mega Rice Project area

99. Agroforestry competences and human resources needs in the Philippines 100.

CES/COS/CIS paradigms for compensation and rewards to enhance environmental Services 
101. Case study approach to region-wide curriculum and teaching materials development in agroforestry education in Southeast Asia

102. Stewardship agreement to reduce emissions from deforestation and degradation (REDD): Lubuk Beringin's Hutan Desa as the first village forest in Indonesia

103. Landscape dynamics over time and space from ecological perspective

104. A performance-based reward for environmental services: an action research case of "RiverCare" in Way Besai sub-watersheds, Lampung, Indonesia

105. Smallholder voluntary carbon scheme: an experience from Nagari Paningahan, West Sumatra, Indonesia

106. Rapid Carbon Stock Appraisal (RACSA) in Kalahan, Nueva Vizcaya, Philippines

107. Tree domestication by ICRAF and partners in the Peruvian Amazon: lessons learned and future prospects in the domain of the Amazon Initiative eco-regional program

108. Memorias del Taller Nacional: "Iniciativas para Reducir la Deforestación en la region Andino - Amazónica", 09 de Abril del 2010. Proyecto REALU Peru

109. Percepciones sobre la Equidad y Eficiencia en la cadena de valor de REDD en Perú Reporte de Talleres en Ucayali, San Martín y Loreto, 2009. Proyecto REALU-Perú.

110. Reducción de emisiones de todos los Usos del Suelo. Reporte del Proyecto REALU Perú Fase 1

111. Programa Alternativas a la Tumba-y-Quema (ASB) en el Perú. Informe Resumen y Síntesis de la Fase II. 2da. versión revisada

112. Estudio de las cadenas de abastecimiento de germoplasma forestal en la amazonía Boliviana

113. Biodiesel in the Amazon

114. Estudio de mercado de semillas forestales en la amazonía Colombiana

115. Estudio de las cadenas de abastecimiento de germoplasma forestal en Ecuador

116. How can systems thinking, social capital and social network analysis help programs achieve impact at scale?

117. Energy policies, forests and local communities in the Ucayali Region, Peruvian Amazon

118. NTFPs as a Source of Livelihood Diversification for Local Communities in the Batang Toru Orangutan Conservation Program

119. Studi Biodiversitas: Apakah agroforestry mampu mengkonservasi keanekaragaman hayati di DAS Konto?

120. Estimasi Karbon Tersimpan di Lahan-lahan Pertanian di DAS Konto, Jawa Timur

121. Implementasi Kaji Cepat Hidrologi (RHA) di Hulu DAS Brantas, Jawa Timur

122. Kaji Cepat Hidrologi di Daerah Aliran Sungai Krueng Peusangan, NAD,Sumatra 



\section{Who we are}

The World Agroforestry Centre is the international leader in the science and practice of integrating 'working trees' on small farms and in rural landscapes. We have invigorated the ancient practice of growing trees on farms, using innovative science for development to transform lives and landscapes.

\section{Our vision}

Our Vision is an 'Agroforestry Transformation' in the developing world resulting in a massive increase in the use of working trees on working landscapes by smallholder rural households that helps ensure security in food, nutrition, income, health, shelter and energy and a regenerated environment.

\section{Our mission}

Our mission is to advance the science and practice of agroforestry to help realize an 'Agroforestry Transformation' throughout the developing world.

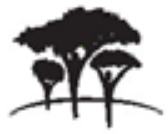

United Nations Avenue, Gigiri - PO Box 30677 - 00100 Nairobi, Kenya Tel: +254207224000 or vla USA +1 6508336645

Fax: +254 207224001 or via USA +1 6508336646

Southeast Asia Regional Programme - Sindang Barang, Bogor 16680

PO Box161 Bogor 16001, Indonesia

Tel: +62 2518625415 - Fax: +62 2518625416

www.worldagroforestry.org 